I N T ER N ATIONAL MONETARY FUND

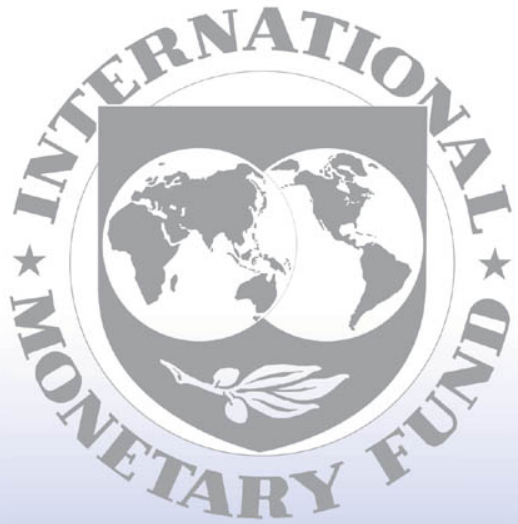

Staff

Country

Reports 


\section{Sierra Leone: Selected Issues and Statistical Appendix}

This Selected Issues paper and Statistical Appendix for Sierra Leone was prepared by a staff team of the International Monetary Fund as background documentation for the periodic consultation with the member country. It is based on the information available at the time it was completed on October 29, 2004. The views expressed in this document are those of the staff team and do not necessarily reflect the views of the government of Sierra Leone or the Executive Board of the IMF.

The policy of publication of staff reports and other documents by the IMF allows for the deletion of market-sensitive information.

To assist the IMF in evaluating the publication policy, reader comments are invited and may be sent by e-mail to publicationpolicy@imf.org.

Copies of this report are available to the public from

International Monetary Fund • Publication Services

700 19th Street, N.W. • Washington, D.C. 20431

Telephone: (202) 6237430 • Telefax: (202) 6237201

E-mail: publications@imf.org • Internet: http://www.imf.org

Price: $\$ 15.00$ a copy

\section{International Monetary Fund Washington, D.C.}


This page intentionally left blank 


\section{INTERNATIONAL MONETARY FUND}

\section{SIERRA LEONE}

\section{Selected Issues and Statistical Appendix}

Prepared by a staff team consisting of Delphin Rwegasira (Head-AFR), Arto Kovanen, Rainer Köhler (all AFR), and Jan Gottschalk (PDR)

Approved by the African Department

October 29, 2004

\section{Contents}

I. Recent Economic Developments.

II. Fiscal Sustainability in Sierra Leone

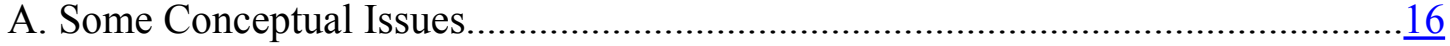

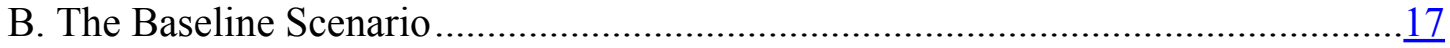

C. Sensitivity Analysis.................................................................................. $\frac{19}{20}$

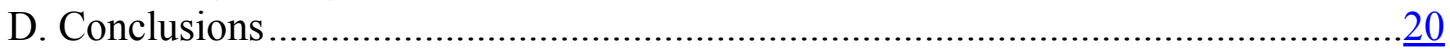

III. Rehabilitating Sierra Leone's Mining Sector-Challenges and the Way Forward...........27

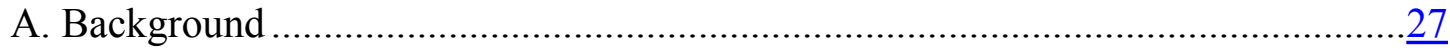

B. Restarting Large-Scale Mining Operations..............................................

C. Regularizing Artisanal Mining Activity .....................................................

Text Box

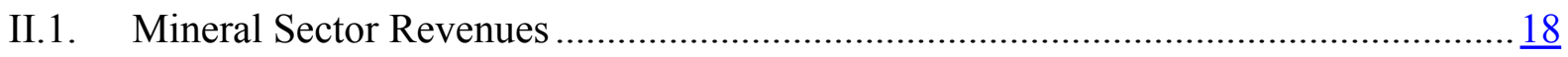

Figures

I.1. Annual Contribution to Real GDP Growth by Sector, 1999-2003 …....................... $\underline{6}$

I.2. Financial Soundness Indicators of the Banking System, 2000-03 ......................... 10

I.3. Selected Economic Indicators..................................................................... $\frac{13}{21}$

II.1. Indicators of Fiscal Performance, 1993-2002 …............................................... $\frac{21}{22}$

II.2. Domestic Source of Government Financing, 1993-2002 .................................... 22

II.3. Indicators of Public Debt Under Alternative Scenarios, 2003-22 ......................... 23 
II.4. Indicators of Public Debt Under Alternative Scenarios, 2003-22......................... 24

II.5. Indicators of Public Debt Under Alternative Scenarios, 2003-22.......................... 25

Text Tables

I.1. Selected Economic and Financial Indicators, 1999-2003 .................................... 4

II.1. Public Sector Debt Sustainability Framework, Baseline Scenarios, 2001-22 _.......... $\underline{26}$

III.1. Export Trends in Sierra Leone ................................................................... 27

Statistical Appendix

Basic Data.

Tables

1. Production of Major Agricultural Commodities, 1998-2003 ................................. $\underline{38}$

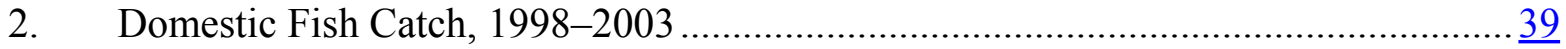

3. Mineral Production, 1998-2003 …................................................................... $\frac{40}{41}$

4. Production of Manufacturing Establishments, 1998-2003 ..................................... 41

5. Petroleum Prices and Utility Tariffs, 2001-03 ..................................................... $\frac{42}{43}$

6. Revised Consumer Price Index for Freetown .................................................. 43

7. Government Budgetary Operations, 1998-2003 …........................................... 44

8. Government Revenue, 1998-2003 …............................................................ 45

9. Economic Classification of Recurrent Expenditure, 1998-2003 ............................. $\underline{46}$

10. Functional Classification of Recurrent Expenditure, 1998-2003 .......................... 47

11. Government Debt Outstanding by Type of Holder and Instrument, 1998-2003 ........ $\underline{48}$

12. List of Public Enterprises......................................................................... 49

13. Summary Account for the Commercial Bank, March 2001-March 2004 _................ $\underline{50}$

14. Commercial Banks Liquidity Ratios, 2001-03............................................... $\frac{51}{52}$

15. Monetary Survey and Summary Accounts of the Bank of Sierra Leone, 2001-03..... $\underline{52}$

16. Distribution of Commercial Bank Loans and Advances by Major Sectors, March 2001-December 2003. $\underline{53}$

17. Structure of Interest Rates, March 2001-March 2004........................................... $\frac{54}{55}$

18. List of Commercial Banks, as at End 2003 …................................................ $\frac{55}{56}$

19. Exchange Rate Developments, 1990-2003 ......................................................... $\frac{56}{57}$

20. Values, Volumes, and Unit Values of Major Commodity Exports, 1998-2003 .......... $\underline{57}$

21. Values, Volumes, and Unit Values of Major Groups of Commodity Imports,

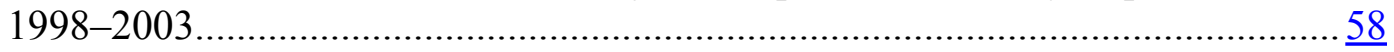

22. External Public Debt and Publicly Guaranteed Debt, 1998-2003........................... $\frac{59}{60}$

23. External Payments Arrears Outstanding, 1998-2003 ........................................... $\underline{60}$

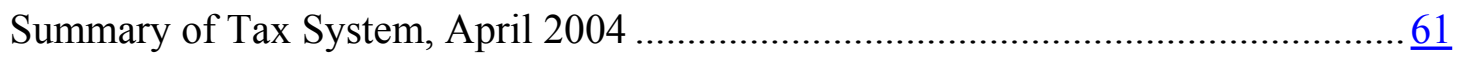




\section{RECENT ECONOMIC DEVELOPMENTS ${ }^{1}$}

\section{A. Background}

1. Sierra Leone remains a poor country despite its rich resource base. Following a protracted war, which began in 1991 when the Revolutionary United Front started campaigning against the government and ended with the signing of the July 1999 peace accord in Lomé, Togo, poverty has become more pervasive. With a real per capita GDP of about US\$130 in 2003, Sierra Leone is well below the average for sub-Saharan African countries. ${ }^{2}$ Furthermore, it ranks last among the 147 countries on the 2004 United Nations' human development index.

2. The IMF and the World Bank Group's International Development Association (IDA) agreed in March 2002 to support a comprehensive debt reduction package for Sierra Leone under the enhanced Heavily Indebted Poor Countries (HIPC) Initiative. Under the decisions made by the IMF and IDA, assistance committed by IDA-US $\$ 122$ million in net present value (NPV) terms - will be delivered over a 20 -year period and will cover, on average, 89 percent of debt-service obligations falling due to IDA. Debt relief provided by the IMFUS\$123 million in NPV terms - will be delivered over the next 10 years. A three-year arrangement under the IMF's Poverty Reduction and Growth Facility (PRGF) was approved in September 2001 in the amount of SDR 130.84 million (126 percent of quota) and was subsequently extended to March 26, 2005.

\section{B. Output and Inflation}

3. Real growth has been rapid in recent years. Improved security and the reestablishment of government control and authority throughout the country have boosted confidence. The economic recovery has benefited especially from the extensive rehabilitation and humanitarian activities in liberated areas. Real GDP growth rose by 4 percent in 2000 and accelerated further in 2001 and 2002 to 18 and 271/2 percent, respectively. ${ }^{3}$ The strong growth was driven mainly by service sector activities (transport, communication, and real estate), construction, and, to a lesser degree, agriculture (crop production, forestry, and fishery). Real GDP for 2003 rose by 9 percent and was broadly based (Table I.1; and Figures I.1 and I.3).

\footnotetext{
${ }^{1}$ Prepared by Rainer Köhler.

${ }^{2}$ Real per capita GDP for sub-Saharan Africa amounted to US\$589.3 (excluding Nigeria and South Africa US\$419.4) in 2003.

${ }^{3}$ However, Sierra Leone's GDP has been revised upward beginning with 2001 by extending the coverage of services such that informal and other sectors' activities are captured. As a result, the GDP growth rates for 2001 to 2003 are substantially higher than the ones published in earlier IMF reports.
} 
Table I.1. Sierra Leone: Selected Economic and Financial Indicators, 1999-2003

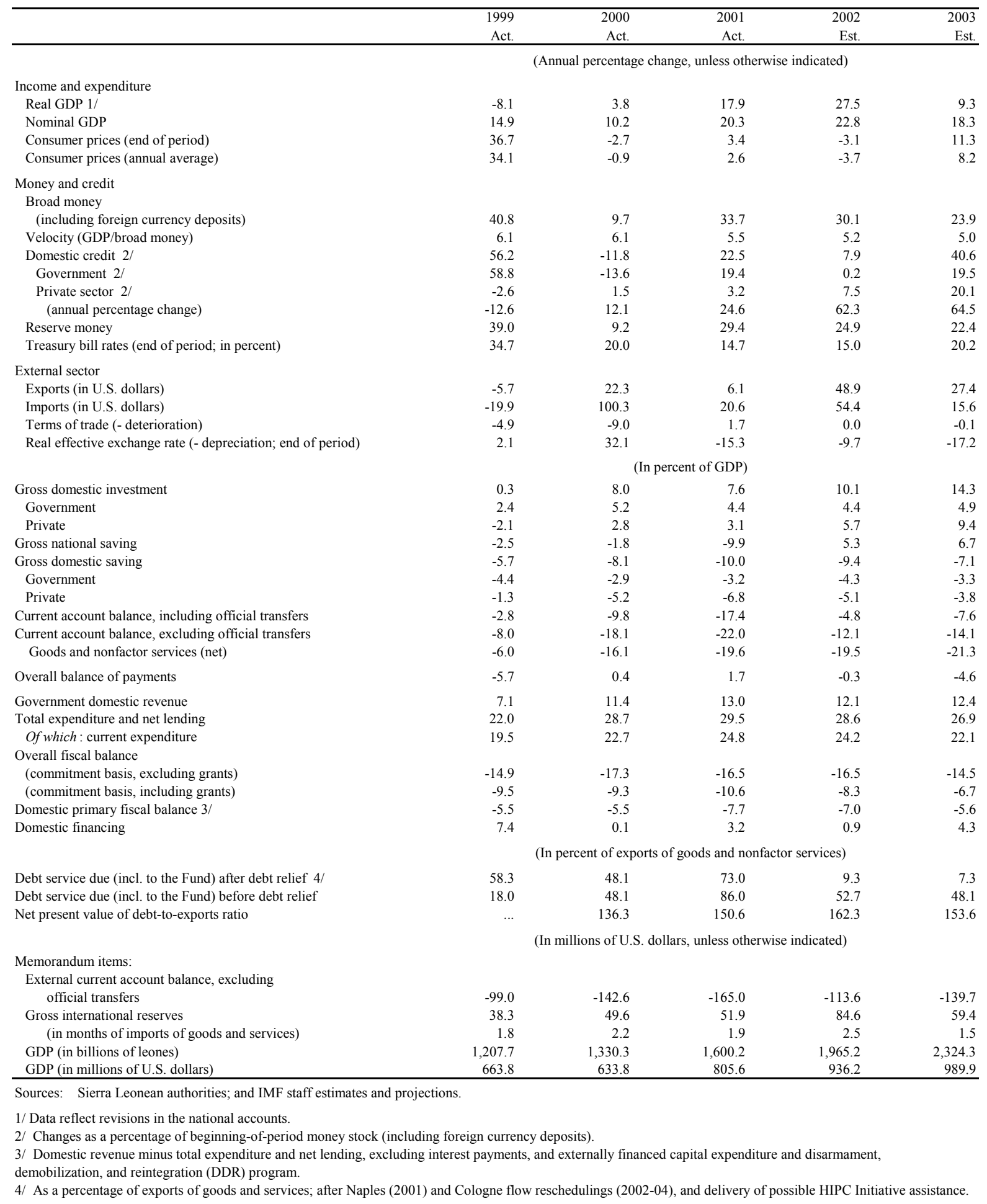




\section{Agricultural production in Sierra Leone accounts for about 40 percent of GDP} and grew on average by about 9 percent during 2000-03. Before the civil war, the agricultural sector generated 52 percent of GDP and employed more than 60 percent of the working population, with coffee and cocoa being the principal export crops and rice being the main food crop. The slow peace process during the first two postconflict years (2000-01) delayed the resettlement of displaced farmers to their original homes and, therefore, the agricultural recovery. Improvements in the security situation during 2002-03 and the resettlement of refugees and internally displaced people in rural areas, facilitated a sharp recovery in agricultural output and rural economic activity. Harvests of rice, cassava, sweet potatoes, and vegetables were rated good in several rural areas (especially Bo, Kenema, Port Loko, Bombali, and Kambia districts). ${ }^{4}$ Stimulated by the increase in the world market prices for coffee and cocoa, the shipment of both commodities increased by 1,164 percent and 84 percent in 2002, respectively, although negligible amounts had been purchased in the previous years. In 2003, the output of rice was up to 78 percent of its prewar level, and cocoa production grew by 134 percent as a result of the continued impetus provided to farmers by the significant rise in cocoa prices in the international market. ${ }^{5}$ The government has pledged to boost agricultural production and achieve food security in Sierra Leone by 2007.

\section{Industrial production accounted for 22 percent of GDP during 2000-03. As} business confidence increased, the production of goods and services also increased. Key manufacturing industries were able to expand production in spite of technical problems associated with aging plant and machinery. A more reliable electricity supply to industries contributed to the expansion in capacity utilization. Growth was particularly strong in light manufacturing, which benefited from the increased imported inputs. In 2003, however, some manufacturing industries registered downturns on account of frequent breakdowns of plant and machinery, and increased consumption of better-quality imported substitutes. As for the mining sector, the production of diamonds, as measured by shipments through the Government Gold and Diamond Office, increased by 57 percent in 2002 and by 44 percent in 2003. The increase was due to intensified mining activities as well as the implementation of the United Nations Certification Scheme. ${ }^{6}$

6. Service activities have contributed substantially to GDP growth since the end of the war. During 2001-02, services expanded by about 60 percent in 2001 and 30 percent in 2002, albeit from low levels in previous years. Developments in transportation and communication (increased registration of taxis and busses, introduction of cellular phones) have supported the strong expansion in services.

\footnotetext{
${ }^{4}$ United Nations, World Food Programme, World Hunger - Sierra Leone, www.wfp.org.

${ }^{5}$ The prolonged political instability in Côte d'Ivoire gave rise to considerable shortages of cocoa in the world market.

${ }^{6}$ The United Nations Certification Scheme was replaced by the Kimberly Process Certification Scheme in June 2003 after the lifting of the ban on "blood diamonds."
} 
Figure I.1. Sierra Leone: Annual Contribution to Real GDP Growth by Sector, 1999-2003 (In percent)

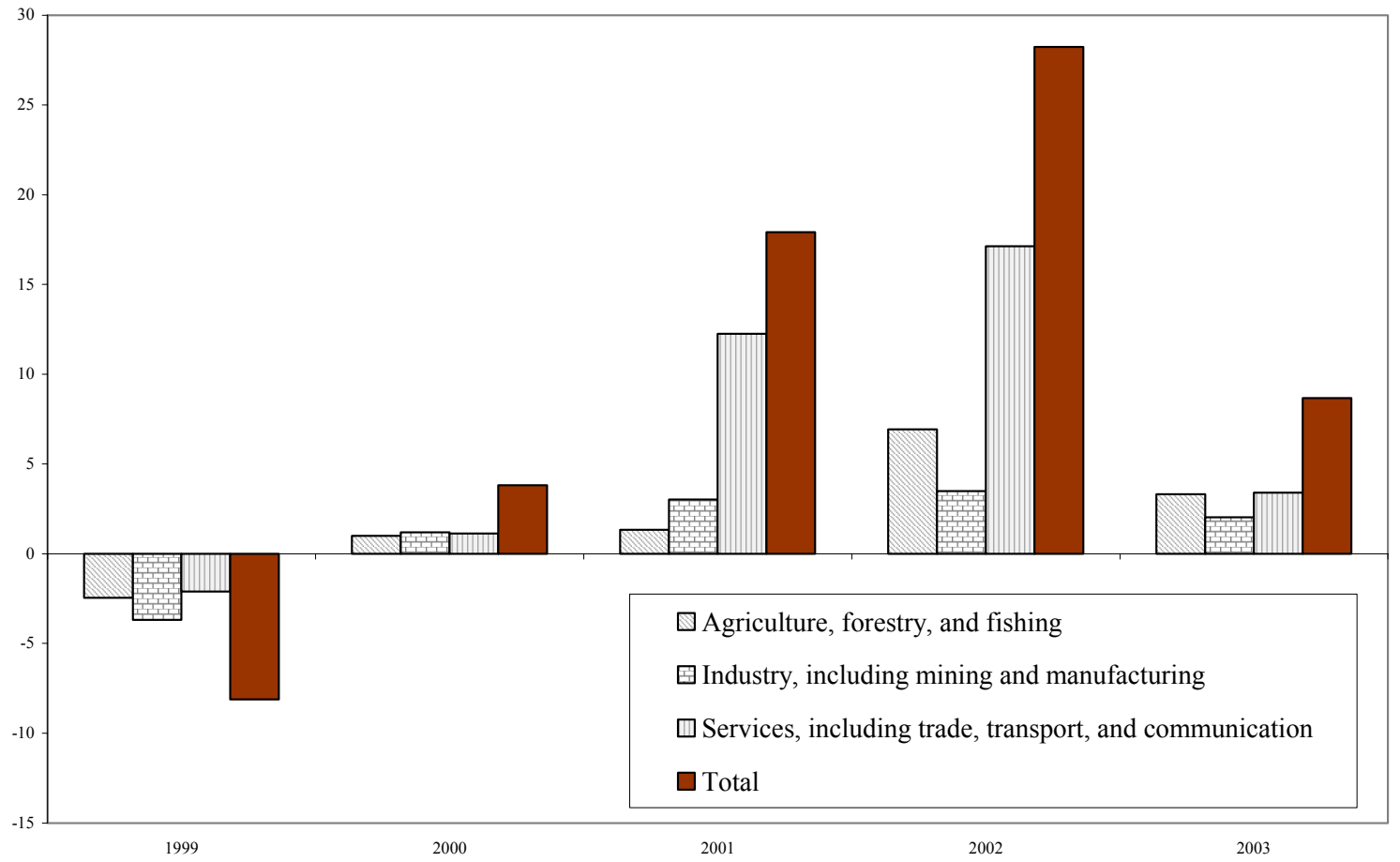

Sources: Statistics Sierra Leone; and IMF staff estimates.

7. Domestic investment and savings during 2000-03 were low, and significantly below the averages for sub-Saharan Africa. ${ }^{7}$ During 2000-03, gross domestic investment represented, on average, about 10 percent of GDP. Public investment, which was largely donor-financed, and private investment (especially in the service sectors of tourism, transportation, and communication) each represented, on average, about 5 percent of GDP. Gross domestic savings were negative during 2000-03 (on average -9 percent of GDP), with public and private savings accounting for about -4 percent and -5 percent of GDP, respectively. The weak domestic savings and investment balance must be seen in light of the damage caused to institutions and infrastructure during the war in the 1990s. The negative public savings stem from the country's weak fiscal position, whereas the negative private savings reflect, for the most part, the extent of poverty. ${ }^{8}$

\footnotetext{
${ }^{7}$ Gross domestic investment and domestic savings each represented, on average, 16 percent of total GDP for sub-Saharan Africa. The data on investment and savings in Sierra Leone are rudimentary because of limited information on the allocation of expenditure.

${ }^{8}$ The proportion of people living in extreme poverty (with expenditures of less than US\$1 a day) increased from 57 percent in 1990 to an estimated 89 percent by 2002. (Sources: World Development Indicators database, UNDP, and Sierra Leonean authorities.)
} 
8. Inflation stabilized following the end of the conflict, but inflationary pressures reemerged in 2003. ${ }^{9}$ After the signing of the peace accord in July 1999, annual average inflation fell sharply from nearly 34 percent in December 1999 to -1 percent in December 2000, as the supply situation improved, macroeconomic policies were tightened, and the exchange rate appreciated in real terms in 2000. Inflation remained low in 2001 and 2002. Several developments accounted for this decline, including further improvements in the supply situation, particularly for imports, increased trade competition, a substantial reduction in import duties, a reduction in domestic petroleum product prices, and the relatively stable exchange rate. However, inflation accelerated in 2003 as a result of higher fuel prices and their effect on transportation costs, the expansion in broad money, and the continued depreciation of the leone against the U.S. dollar and other international currencies.

\section{Fiscal Developments}

9. Fiscal performance was uneven during 2000-03. Reflecting weak revenue performance and high expenditures, the overall deficit (excluding grants) remained large. The fiscal deficit was financed largely from external sources (between 6 and 8 percent of GDP), comprising economic recovery and rehabilitation credits and loans from IDA and the African Development Bank (AfDB). In addition, domestic financing of the budget has been large (Table I.1; and Figure I.3).

10. Revenues were higher than budgeted. However, as a percentage of GDP they have remained low, with little progress in raising the revenue share. Increased revenue collections reflect rising customs duty receipts, greater reliance on presumptive income taxes, and, to a lesser extent, improved tax administration, including a sustained drive to collect tax arrears. The revenue performance also reflects a substantial rise in commercial activities in the manufacturing, construction, trade, and service sectors. Nontax revenues from the mining sector rose as more mining licenses were issued and improved mechanisms for certifying diamonds for export were put in place. The establishment of the National Revenue Authority in 2003 also contributed to revenue collections.

11. There have been improvements in expenditure control. Fiscal discipline was strengthened by the implementation of computerized systems to monitor and control expenditures and to control payroll and pensions. However, significant differences remain between planned and actual expenditures. For example, Sierra Leone has limited administrative ability to implement capital projects. Substantial amounts of multilateral and bilateral project financing had been committed but were not fully used because of security and capacity constraints. In respect of goods and services, there was strong pressure on the government to increase outlays, especially for the deployment of police and the provision of

\footnotetext{
${ }^{9}$ Four consumer price indices are produced in Sierra Leone - one each for four urban towns, namely Freetown, Bo, Kenema, and Makeni. The Freetown CPI is the one used to indicate official price developments in Sierra Leone.
} 
other services. In 2003, fees, subsidies, and financial assistance to educational institutions and the Ministry of Health and Sanitation contributed to an increase in expenditure.

\section{Shortfalls in external budgetary support led to greater than programmed} recourse to domestic financing of the budget. Frequent delays in the disbursement of external budgetary assistance (excluding project-related assistance) complicated fiscal management and led to higher domestic financing. During 2001, some of the delays were related to required audits of prior aid use. In the case of budgetary assistance from the EU, a dispute about audits done for 1998 and 1999, together with delays in fielding an audit for aid disbursed in 2000, led to the postponement of further aid disbursements. The shortfall in foreign financing during 2003 arose in part because of an administrative delay in conducting an audit that constituted part of EU grant conditionality. Another cause of the shortfall was a delay in a loan disbursement from the AfDF. The Board of the AfDF approved the second Economic Rehabilitation and Recovery Loan for Sierra Leone in December 2003, and disbursement was made in April 2004. As a result of rising domestic borrowing, domestic interest outlays were much higher than programmed.

13. The government had difficulty in managing the wage bill. Strong fiscal pressures in 2000 to increase outlays reflected demands for higher allowances for civil servants, an increase in the wage bill to pay former soldiers put back on the payroll, and outlays on defense and security. In response, the government raised expenditure ceilings, which were financed by higher-than-programmed revenue and external budgetary support. In 2001, a substantial overrun on the wage bill occurred ( 0.7 percent of GDP) mainly because of higherthan-budgeted wage and salary payments to teachers. ${ }^{10}$ The planned wage bill was exceeded in 2002, reflecting continuing difficulties in managing teachers' payroll and the settlement of a strike by health workers (which raised nurses' and doctors' pay well above budgeted levels). ${ }^{11}$ To bring teachers' salaries under control, the government introduced a number of measures in 2003 that strengthened financial accountability for teachers' payments and streamlined administrative procedures. The wage bill in 2003 only slightly exceeded the programmed level, reflecting, in part, the unprogrammed clearance of wage arrears.

\section{Monetary Sector}

14. Broad money growth accelerated during 2000-01 as a result of rising economic activity and remonetization of the economy. Monetary conditions were dominated by fiscal developments. The money supply rose as a result of the large increase in net bank

\footnotetext{
${ }^{10}$ The actual number of teachers paid in 2001 was about 20,500 although the 2001 budget provided for 17,500. Measures were introduced in the second half of 2002 to strengthen budgeting and control of the teachers' payroll. An audit revealed that, of the 22,497 teachers on the payroll in 2002, the employment of 2,446 could not be verified.

${ }^{11}$ The wage bill accounted for 33 percent of total recurrent expenditure and 62 percent of total tax revenue.
} 
credit to the government. Faced with a significant increase in their deposit base and limited growth in private sector credit in 2001, commercial banks competed to augment their share of government securities. As a result, and owing to low inflation, nominal yields on treasury bills and government bonds generally declined. The treasury bill rate fell from 20 percent in December 2000 to a low of 8.6 percent in February 2001 before rising to 14.7 percent in December 2001 (Table I.1; and Figure I.3). The spread between bank loan and deposit rates, having narrowed only marginally in response to the decline in treasury bill and bond yields, remained wide (20-30 percent).

\section{Monetary policy during 2002-03 accommodated the expansionary fiscal stance} and allowed the private sector credit to continue to grow at a rapid pace. The rapid increase in broad money can be attributed to the faster-than-programmed expansion in bank domestic assets. Private sector credit started to grow rapidly in 2002 and increased by nearly 65 percent in 2003. The sectors accounting for this increase were commerce and finance, manufacturing, construction, and services, signifying a pickup in economic activity in these sectors from low post-conflict levels. The banking system's net credit to the government also increased substantially. The yield on treasury bills at end-2003 was 20.2 percent compared with 15 percent a year earlier.

16. The banking sector of Sierra Leone remains very small and highly liquid. At the end of 2003, broad money was equivalent to about 20 percent of GDP. The major financial institutions comprise six commercial banks - three local, of which one is 100 percent stateowned, and three foreign. The banking system's assets increased by 91 percent during December 2000-03, a rise fueled, on the liability side, by a rapid growth of banking system deposits (108 percent). On a risk-weighted basis, banks' capitalization increased to 40 percent in 2003 from 25 percent in 2000 (Figure I.2). ${ }^{12}$ Reported capitalization figures reflect the high level of government securities in banks' balance sheets. The commercial banks' ratio of nonperforming loans to total bank loans continued to decline to slightly below 10 percent in December 2003 from 38 percent at end-2000; the decline has been attributed, in part, to the repayment of government arrears to enterprises, but also to the rapid increase in credits to the private sector (64 percent in December 2003 from end-year 2002). The overall ratio of liquid assets to deposits grew from 67 percent in 2000 to 71 percent in 2003. In an environment of rapidly expanding banking activities and high real interest rates, the commercial banks have been able to remain profitable, as measured by their return to equity (33 percent in December 2003).

\footnotetext{
${ }^{12}$ Since 2001, commercial banks have been subject to the tighter capital adequacy requirement of 15 percent of risk-weighted assets under the new Banking Act of the Bank of Sierra Leone.
} 
Figure I.2. Sierra Leone: Financial Soundness Indicators of the Banking System, 2000-03 (In percent)

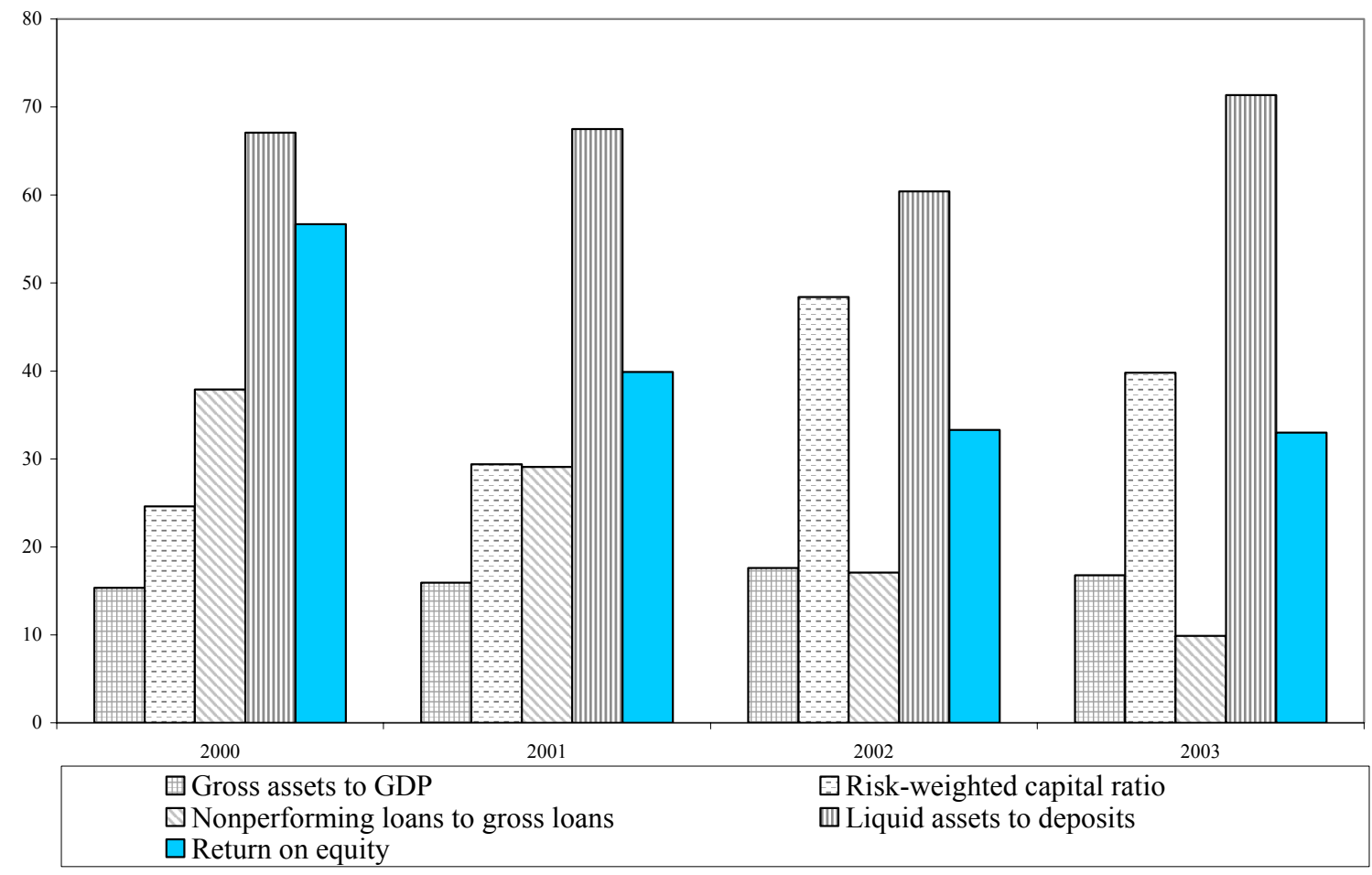

\section{E. External Sector}

17. The external current account deficit (excluding official transfers) has remained large since the end of the conflict in July 1999. This reflects the sharp increase in commercial and humanitarian relief imports, as well as the country's limited export capacity (still operating below potential). The current account deficit in 2000 was financed by foreign grants and concessional loans, and the capital account balance improved markedly as a result of larger official inflows (Table I.1; and Figure I.3).

18. Exports started to recover in 2001. The implementation of the UN-sponsored diamond export certification scheme helped raise the level of officially recorded diamond exports to US\$26.3 million in 2001 from US\$10.1 million in 2000. Nonetheless, the 2001 level was a small fraction of total diamond exports. ${ }^{13}$

19. Proceeds from officially exported diamonds increased by 59 percent in 2002 , reaching the highest level since 1985. The impressive performance in the export of diamonds can be attributed to the increased mining activities and improved incentives and

\footnotetext{
${ }^{13}$ Bilateral trade partner data for Sierra Leone suggest that total diamond exports totaled about US\$74.3 million in 2001.
} 
logistics for mine wardens and also to the more effective implementation of the certificate of origin scheme. In addition, strong recovery in coffee and cocoa production led to a substantial increase in these exports.

20. On the import side, the increased availability of foreign exchange to importers improved business confidence, and greater economic activity contributed to rising imports. The surge in imports in part reflected UN and NGO operations, while the increases in the value of machinery and transport equipment are explained by increased investment. Private capital inflows, including from NGOs and the UNAMSIL, helped to finance imports.

21. Sierra Leone's external current account deficit in 2003 rose to about 14 percent of GDP, reflecting increased imports related to reconstruction activities and the higher cost of fuel. Foreign trade during 2003 rose by 23 percent from a year earlier, as manifested in the significant increases in both import payments (owing to a general rise in commercial activity) and export receipts (owing to a further boost in mining and agricultural output). Officially recorded diamond exports have benefited from the international adoption of the Kimberley Process Certification Scheme; as a result, proceeds from the export of diamonds increased by 83 percent in 2003. Agricultural exports also expanded strongly but continued to account for only a small share of total exports. Export earnings from agricultural commodities increased by 71 percent, mainly because of a market rise in cocoa exports. The total import bill showed an increase of about 16 percent over 2002. Import growth was mainly driven by payments for petroleum products, machinery, transport equipment, and manufactured goods for reconstruction activity. The increase in petroleum imports reflected higher volumes to meet rising domestic consumption as well as an increase in world market prices for petroleum products.

22. Sierra Leone's foreign exchange market operations have improved. The introduction of the foreign exchange auction in early February 2000 has reduced the parallel exchange market operations and lowered the spread between official and parallel market exchange rates, from an average of 34 percent in 1999 to 10 percent in $2000 .{ }^{14}$ This development was associated with a sharp appreciation of the leone against the U.S. dollar (by 32 percent in real terms) in 2000 as the economy started to stabilize. However, with the increasing demand for foreign exchange, combined with uncertainty associated with the disbursements of external program assistance, the real effective exchange rate of the leone depreciated by 14 percent during 2001-03.

23. Gross official reserves of the Bank of Sierra Leone have been under pressure. The import cover peaked at 2.5 months in 2002, but declined to 1.5 months by end-2003 because some program receipts expected in 2003 were not disbursed.

\footnotetext{
${ }^{14}$ Sierra Leone maintains a flexible exchange rate system. The auction market was introduced to address inefficiencies in the pricing and allocation of foreign exchange.
} 


\section{Since reaching its decision point under the enhanced HIPC Initiative in March} 2002, Sierra Leone has received substantial assurances of HIPC assistance from

creditors. Most multilateral creditors (IMF, World Bank, African Development Bank, and European Commission/European Investment Bank) and Paris Club creditors are providing interim assistance to Sierra Leone. Bilateral creditors have also provided debt relief, but on terms that fall short of that provided by the Paris Club creditors. ${ }^{15}$ Despite the authorities' efforts, Sierra Leone has made relatively little progress in settling its commercial arrears, and some commercial creditors have resorted to litigation.

\footnotetext{
${ }^{15}$ The Paris Club countries agreed on July 10, 2002, to top up the debt relief from Naples to Cologne terms.
} 
Figure I.3. Sierra Leone: Selected Economic Indicators

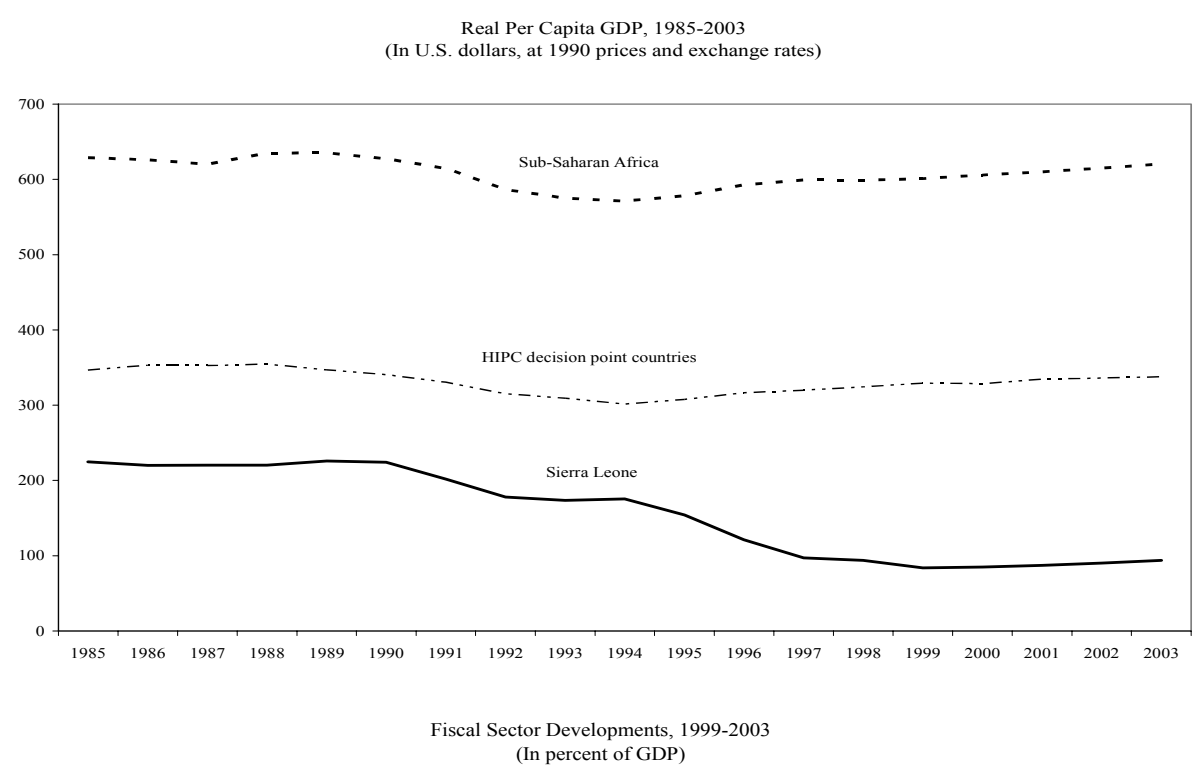
(In percent of GDP)

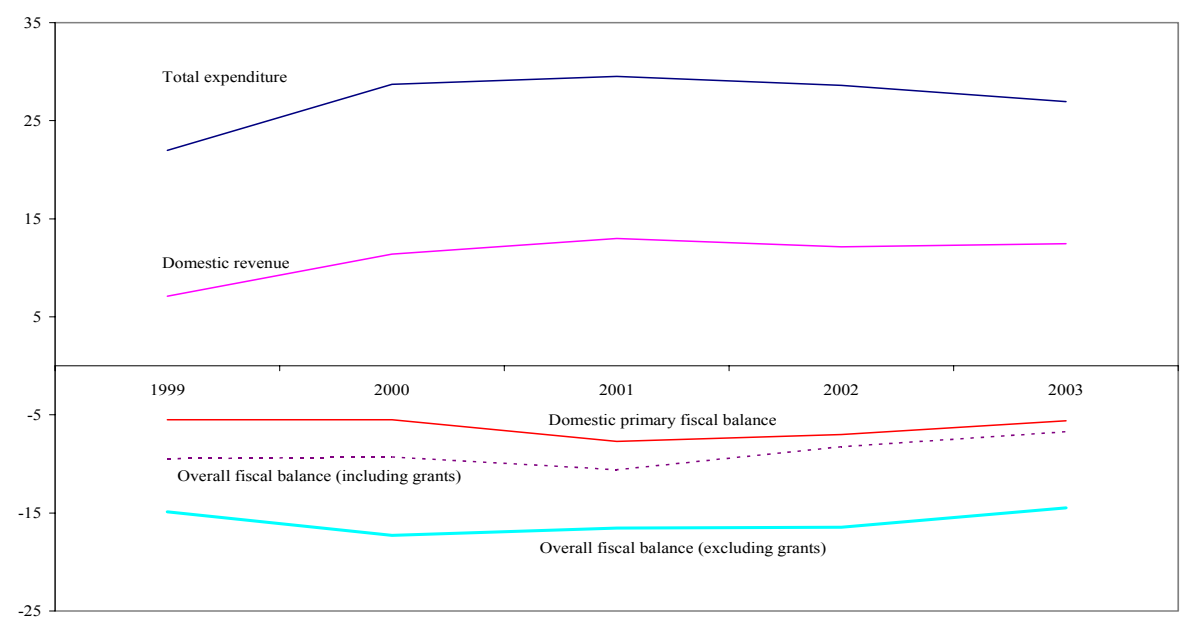

Inflation, Money Growth, and Interest Rate, 2000-03 (In percent)

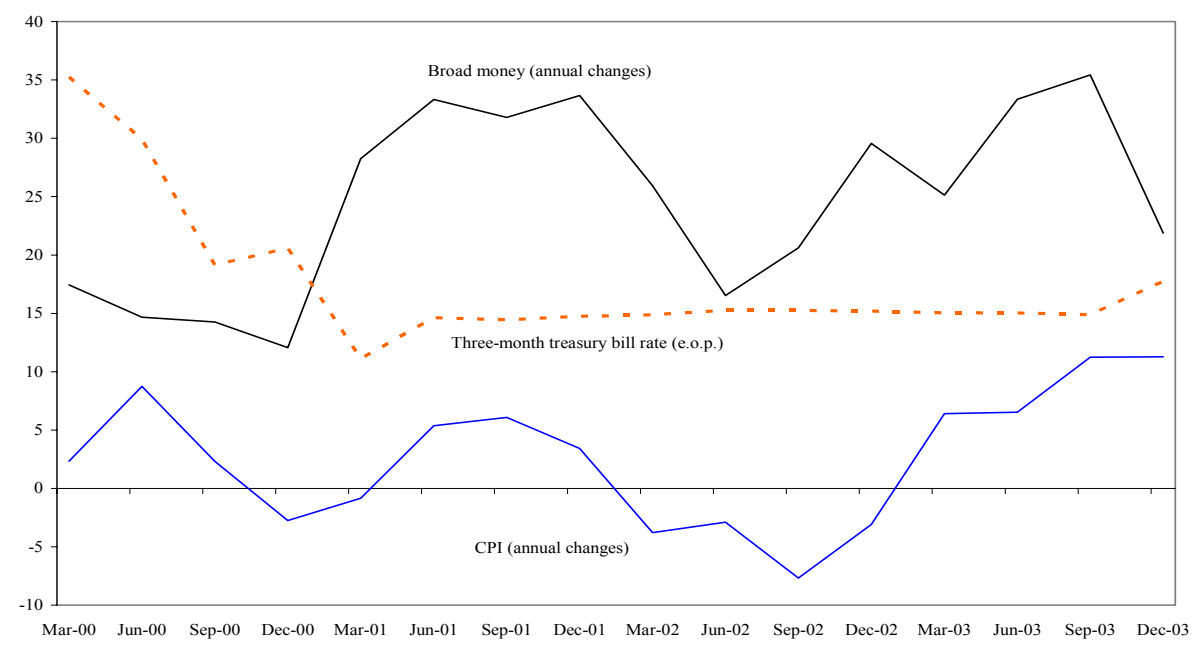



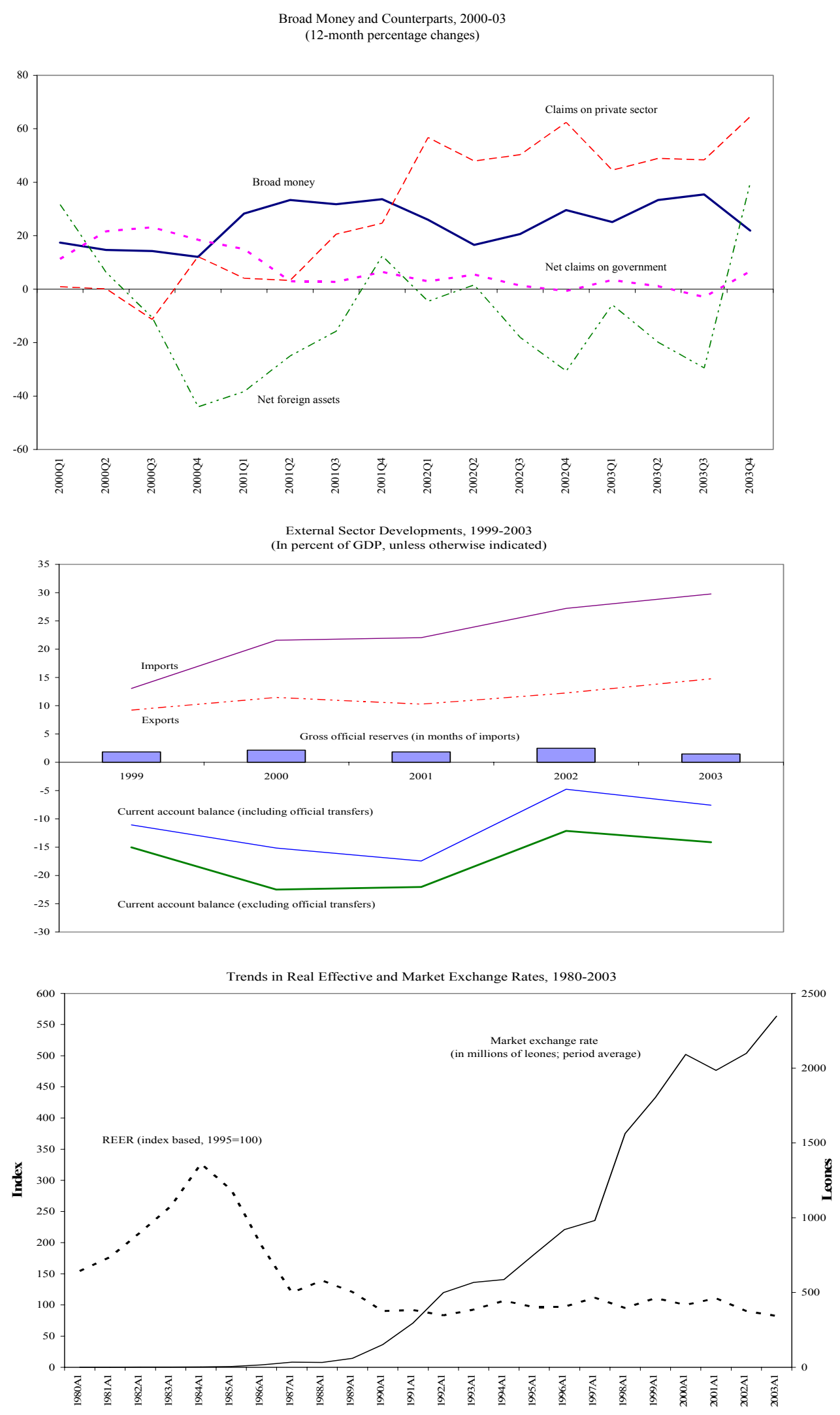


\section{Fiscal SUStainabiLITY IN SIERRA LEONE ${ }^{16}$}

1. During the 1990s, Sierra Leone's macroeconomic performance was undermined by the prolonged civil conflict and political instability. These are reflected in negative real growth and high inflation, together with large volatility in both (Table II.1).

2. During this period, the government's fiscal performance was also generally weak. Overall fiscal deficits averaged 7.5 percent of GDP (Figure II.1), while primary deficits were somewhat smaller. The fiscal positions came about because of weak revenue efforts (domestic revenues as a percentage of GDP averaged only slightly higher than 10 percent). Although total noninterest expenditures during this period (at about 18 percent of GDP) were in line with those of other HIPC countries, and somewhat lower than for subSaharan Africa as a whole ${ }^{17}$, the government could not finance them without resorting to foreign borrowing (historically, domestic debt has been short term and a rather small portion of the overall debt stock). ${ }^{18}$

3. Macroeconomic performance has improved since 2001. Real growth has picked up since the economy returned to normalcy in 2001. By strengthening fiscal and monetary policies the government has brought inflation down to more manageable levels. As a result, primary and overall fiscal balances have improved, while the debt-to-GDP ratio has fallen partly as a result of external debt relief granted under the HIPC Initiative.

\section{Historically the government budget has depended heavily on foreign grant} financing, with foreign grants comprising between 30-70 percent of budget financing. In recent years, the share has averaged about 50 percent. This heavy dependence on foreign financing, together with uncertainty about the disbursements of grants, has complicated fiscal management.

5. Fiscal pressures are likely to continue in the medium term. As the government's focus shifts from post conflict stabilization toward medium-term development and poverty alleviation, in the context of its poverty reduction strategy, it needs to prioritize many demands on the basis of domestic and external resources.

\footnotetext{
${ }^{16}$ Prepared by Arto Kovanen. The analysis in the paper is based on the fiscal sustainability template developed by the staff for low-income countries.

${ }^{17}$ The unweighted average noninterest expenditure for sub-Saharan African countries during 1993-2002 is 21.3 percent of GDP.

${ }^{18}$ The increase in the share of domestic debt (Figure II.2) is to some extent, due to debt issued to the Bank of Sierra Leone as part of the bank recapitalization scheme.
} 
6. In what follows, Section A lays out some conceptual issues for the analysis of government debt sustainability, while sections $\mathrm{B}$ and $\mathrm{C}$ discuss key issues related to long term fiscal sustainability. Section D concludes.

\section{A. Some Conceptual Issues}

7. Given the nature of government's operations, sustainability has to be considered in an intertemporal framework. In general terms, sustainability means that the government can satisfy the net present value of future budget constraints without significant corrections to its revenues or expenditure to avoid insolvency or illiquidity. ${ }^{19}$

8. When the present value of current and future primary expenditures does not exceed the present value of current and future streams of income, net of any initial indebtedness, the government is solvent. That is,

$$
\sum_{i=0}^{\infty} \frac{E_{t+i}}{\prod_{j=1}^{i}\left(1+r_{t+j}\right)} \leq \sum_{i=0}^{\infty} \frac{Y_{t+i}}{\prod_{j=1}^{i}\left(1+r_{t+j}\right)}-\left(1+r_{t}\right) D_{t-1},
$$

where $E_{t}$ is the primary expenditure (total expenditure minus interest payment) at period $t$, $Y_{t}$ is the government income (GDP for a country), $D_{t-1}$ is the end-of-period debt stock at $t$-1, and $r_{t}$ is the nominal interest rate. When liquid assets and available financing are sufficient to meet all maturing liabilities, regardless of whether the solvency condition is satisfied, the government is said to be liquid.

9. On the basis of the above general definition, the government's debts can be considered sustainable when the government can repay its current debt stock with future primary surpluses:

$$
D_{t}=\sum_{i=0}^{\infty} \frac{P B_{t+i}}{\prod_{j=0}^{i}\left(1+r_{t+j}\right)}=\sum_{i=0}^{\infty} \frac{Z_{t+i}}{\prod_{j=0}^{i}\left(1+r_{t+j}\right)}-\sum_{i=0}^{\infty} \frac{E_{t+i}}{\prod_{j=0}^{i}\left(1+r_{t+j}\right)},
$$

where $P B_{t}$ is the primary balance and $Z_{t}$ is government revenue (including foreign grants).

\footnotetext{
${ }^{19}$ See, for example, Nigel Chalk and Richard Hemming, "Assessing Fiscal Sustainability in Theory and Practice," IMF Working Paper WP/00/81 (Washington: International Monetary Fund), 2000.
} 
10. Equation (2) can be modified to distinguish between domestic and external debt:

$$
D_{t}=D D_{t}+\varepsilon_{t} D E_{t}=\sum_{i=0}^{\infty}\left(\frac{\left(1-\lambda_{t+i}\right)}{\prod_{j=0}^{i}\left(1+r_{t+j}\right)}+\frac{\lambda_{t+i} \varepsilon_{t} \prod_{j=0}^{i}\left(1+q_{t+j}\right)}{\prod_{j=0}^{i}\left(1+r_{t+i}^{*}\right)}\right) P B_{t+i},
$$

where $D D_{t}$ is the beginning-period stock of government domestic debt denominated in local currency at period $t, D E_{t}$ is the beginning-period stock of government external debt in term of foreign currency units, $\varepsilon_{t}$ is the nominal exchange rate (Leone per foreign currency), $\lambda_{t}$ is the share of external borrowing needed to finance primary deficits, $q_{t}$ is the rate of appreciation of the nominal exchange rate, and $r_{t}^{*}$ is the nominal interest rate charged on external debt.

11. Equation (3) indicates that the key variables for determining fiscal debt sustainability are government revenue, primary expenditure, debt stock (domestic and external), the cost of borrowing (that is, domestic and foreign nominal interest rates), and nominal exchange rate. Higher output and inflation will influence fiscal sustainability not only through changes in the denominator (ratios to GDP) but also through their effect on key variables determining the government's fiscal position (such as tax revenues, inflation, and the exchange rate).

\section{B. The Baseline Scenario}

12. The baseline scenario assumes sustained high output growth together with low inflation. ${ }^{20}$ Real output is projected to grow between 6-7 percent a year in the projected period, with inflation dropping to low single digits. Given their substantial roles in the economy, agriculture and mining, as well as investment in these sectors, would be the key driving forces of growth.

13. The primary balance is projected to strengthen. This strengthening is brought about both by a stronger domestic revenue effort, measured in terms of percent of GDP, and by the augmentation of the revenue base. Through the addition of revenues from the mineral sector, which is projected to expand considerably during the next 5-7 years as new mining projects are brought to production (Box 1). Although the introduction of the common external tariff for the Economic Community of West African States (ECOWAS) could result in a small revenue loss (possibly $1 / 2$ a percentage point of GDP), the broadening of the tax base, in the context of a value-added tax system, to services and other products not currently taxed would benefit the government. Furthermore, the government should increase its effort to collect income taxes, as well as increasing the share of personal taxes collected (currently only about $1 \frac{1}{2}$ percent of GDP in tax revenue is derived from personal income taxes).

${ }^{20}$ Projections comprise the period 2004-22. 
14. An improved revenue effort will be required to compensate for the projected decline in foreign grants, from 40 percent of total revenues and grants in 2003 to below 10 percent by the year 2022 . However, additional resources not currently projected could become available in the context of the PRSP and the MDGs. If they did not, a larger share of current expenditures would need to be covered by domestic revenues, which represents an important shift from the prevailing high dependency on foreign donor support.

\section{Box 1. Sierra Leone: Mineral Sector Revenues}

The medium-term fiscal revenue projections incorporate forecasts of the revenue streams from major mineral projects (including kimberlite, rutile, bauxite, and gold). Sierra Leone has few relatively large mining projects and IMF staff has projected revenues separately for each one.

Although reasonable forecasts have been used for price, cost, and production developments, they are subject to downside risks (for example, price forecasts underpinning the projections may turn out to be too optimistic, production could be postponed, development and operational costs could turn out to be higher than initially projected, and the fiscal regime could change) as well as upside risks (for example, the realized price, cost, and production figures could be more favorable than initially projected; and new mineral deposits could be discovered). To avoid overstating the medium-term projections, a 15 percent discount factor has been applied to the baseline projections to account for potential downside risks.

In the discounted scenario, mineral revenues are projected to comprise 0.4 percent of GDP in 2004. This figure is projected to increase to 1 percent of GDP by 2008 and to increase by 1 percent more in the subsequent years.

15. To facilitate fiscal sustainability in the long run, the government needs to reduce expenditures, other than interest payments (Table II.1). It should achieve reductions in part through cost cutting, rationalization of government operations, and other reforms to contain costs and improve efficiency. Furthermore, the government needs to prioritize outlays according to the country's developmental and poverty-related needs (the poverty reduction strategy should provide key guidance on this). The share of investment expenditure needs to be increased to promote high output growth.

\section{The long-run debt-to-GDP and debt-to-revenue ratios are projected to fall}

(Figure II.3.). The baseline scenario is illustrated. As a result of fiscal consolidation and improved fiscal management, the staff projects declines in the debt-to-GDP and in the debtto-revenue ratios while the ratio of debt service to revenue is projected to remain broadly stable in the long run. In part, these outcomes are assisted by debt forgiveness under the HIPC Initiative, which will lower the net present value of external public debt. Moreover, lower domestic borrowing (as a percentage of GDP) helps alleviate the rising cost of borrowing from domestic sources, a key medium-term risk to fiscal sustainability in Sierra Leone (the share of domestic debt to total debt stock is projected to fall from 41 percent in 
2003 to 18 percent in 2022). The share of foreign currency debt is projected to rise towards the end of projected period.

\section{Sensitivity Analysis}

17. The overall macroeconomic environment in which the government is operating will affect the fiscal outcome and, by extension, fiscal sustainability. That is, changes in real growth and inflation, as well as in the external environment, would need to be offset by fiscal adjustments to preserve long-term fiscal sustainability. Private sector consumption and saving decisions affect interest rates and the cost and level of private investment activity and, eventually, economic growth and the government's revenue collections and ability to spend on various public programs. Foreign investments in the country are equally important for supporting domestic activities and export growth. Expectations and public confidence in the government's ability to implement appropriate economic policies influence private sector decisions and, hence, need to be fostered.

18. We therefore conduct a series of tests, with other things being equal, to see how sensitive the above conclusions are if there were a domestic or external shock. The test results suggest that, in the face of significant macroeconomic shocks, the fiscal debt could not be sustained in the long run.

19. Improved macroeconomic performance and fiscal balance are essential for fiscal sustainability (Figure II.3). Using historical averages for output growth and the primary balance, we find that unless such improvements occur, the debt will be unsustainable in the long run. Although the unsustainability reflects the country's volatile past, it also suggests that Sierra Leone needs to maintain high output growth and broadly balance its primary position in the medium term; otherwise, the public debt is likely to remain unsustainable. The need for further fiscal consolidation is reinforced by the results of the "no reform" scenario, in which where the fiscal primary balance is maintained constant at its 2002 level.

20. A temporary negative output shock leads to an unsustainable fiscal adjustment and rapidly rising debt-to-GDP and debt service ratios (Figure II.4). ${ }^{21}$ This is because total expenditures, as a percent of GDP, would increase significantly if nominal GDP is declining and lead to a larger primary deficit and borrowing. A temporary worsening of the primary balance, which could be caused, for example, by delays in external grants, will not necessarily affect the government's long-term fiscal position permanently, provided that the authorities adjust the medium-term fiscal portfolio to make the debt sustainable. A transitory real exchange rate shock could permanently lower the debt-to-GDP and debt-to-revenue

${ }^{21}$ Simulated by shocking the system with one standard deviation of real output in 2004-05. 
ratios (Figure II.5). ${ }^{22}$ The effect of such a shock would be felt as the domestic currency value of foreign currency debt changed.

21. Liquidity risk could arise from a higher rollover of short-term domestic debt. In Sierra Leone, virtually all domestic public debt is short-term. ${ }^{23}$ Since no long-term domestic debt instruments (beyond the maturity of one year) are available, the government will have to finance all future borrowing by issuing short-term debt. In the long run, this will result in a situation where virtually all domestic debt would be short term. Given the size of the domestic debt stock, equal to about 41 percent of GDP at end-2003, the debt carries a significant rollover risk. ${ }^{24}$ With a view to addressing the high rollover and liquidity risks, the government should promote domestic debt markets that would enable it to issue longer-term debt securities to finance its fiscal deficit.

22. Privatization of state-owned enterprises could promote fiscal sustainability. Revenues from the sale of state assets could be used to finance poverty-related expenditures or lower the stock of domestic debt.

\section{Conclusions}

23. Sierra Leone needs to achieve fiscal sustainability through a mixture of revenue and expenditure measures that will allow it to balance its primary fiscal position. The process will be much assisted by the assumed external debt forgiveness in the context of the HIPC Initiative, which lowers the share of external debt and, hence, provides room for additional domestic borrowing. There are, however, significant risks to this scenario arising from negative shocks to real growth and the primary deficit. The authorities also need to address rollover and associated liquidity risks caused by the short maturity of domestic debt. They can do so by extending the maturity of domestic debt.

${ }^{22}$ The shock comprised a 30 percent real depreciation in 2004.

${ }^{23}$ The remainder comprises debt in the Bank of Sierra Leone balance sheet that bears no interest.

${ }^{24}$ If the three-month treasury bills are used to refinance domestic borrowing, the debt stock would be rolled over four times in a year. 
Figure II.1. Sierra Leone: Indicators of Fiscal Performance, 1993-2002 (Percent of GDP)

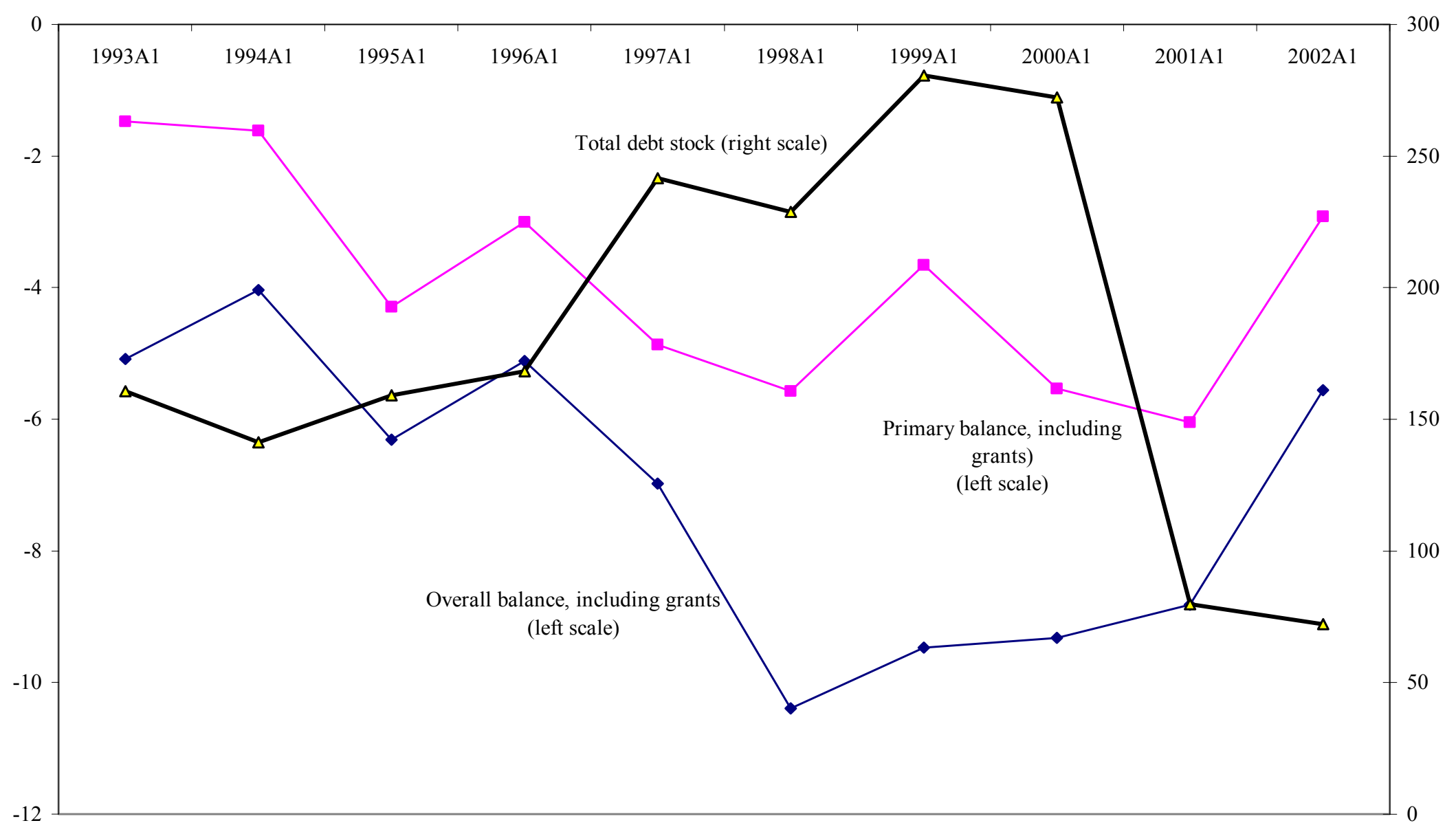

Sources: Sierra Leonean authorities, and staff estimates and projections. 
Figure II.2. Sierra Leone: Domestic Source of Government Financing, 1993-2002 (In percent)

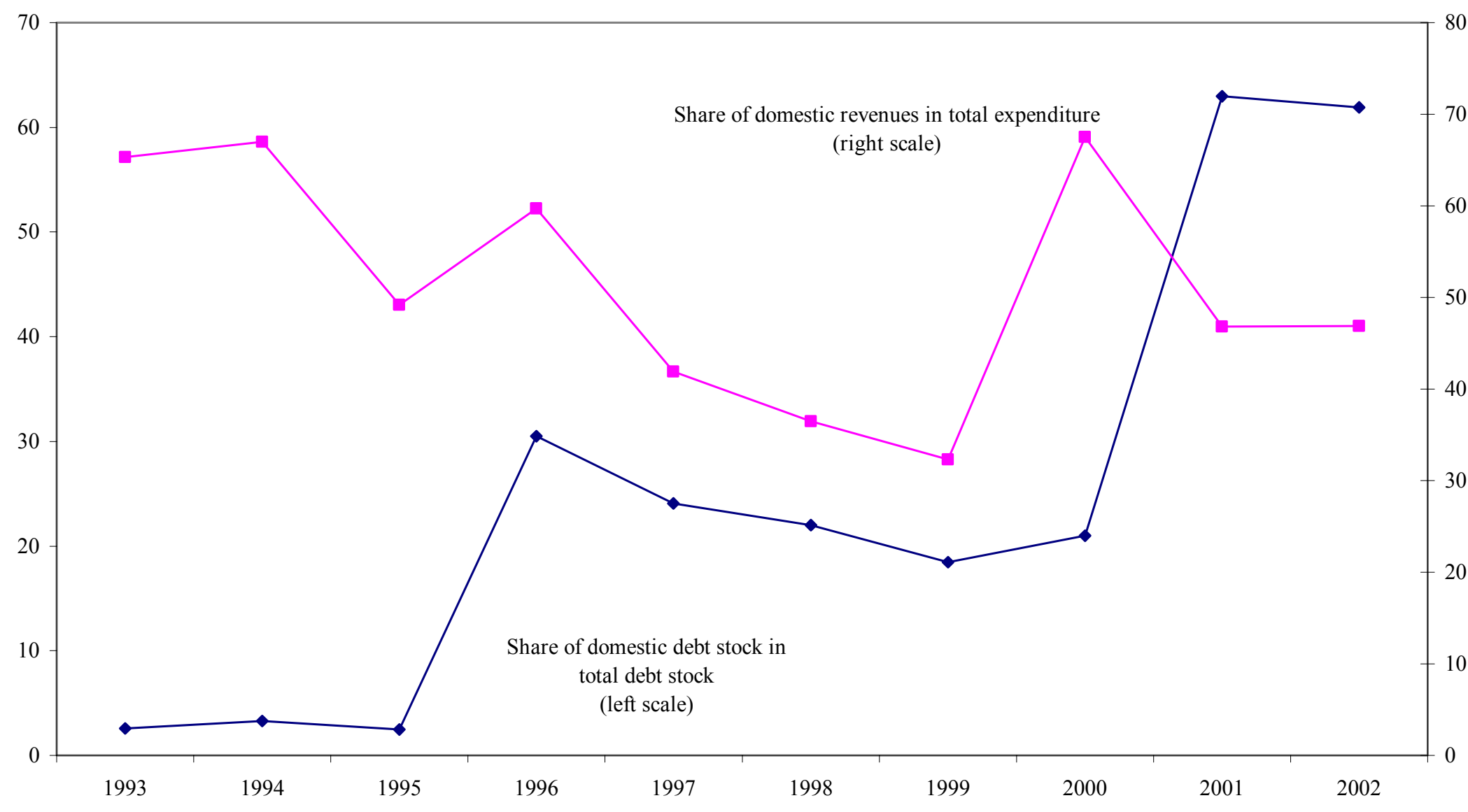

Sources: Sierra Leonean authorities, and staff estimates and projections. 
Figure II.3. Sierra Leone: Indicators of Public Debt Under Alternative Scenarios, 2003-22 1/ (In percent)

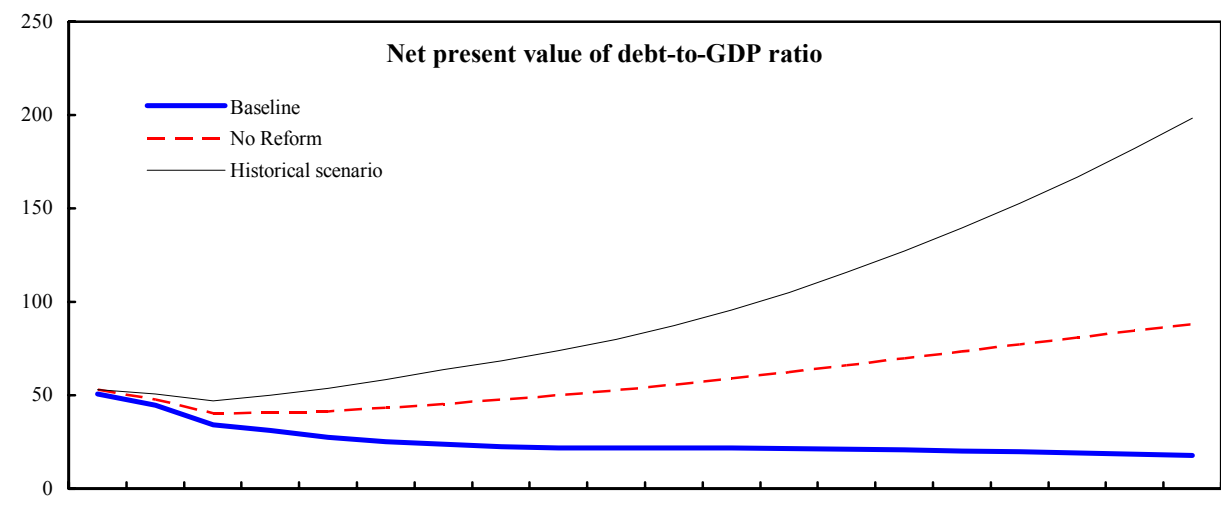

$2003200420052006200720082009201020112012 \quad 2013 \quad 2014 \quad 20152016201720182019202020212022$

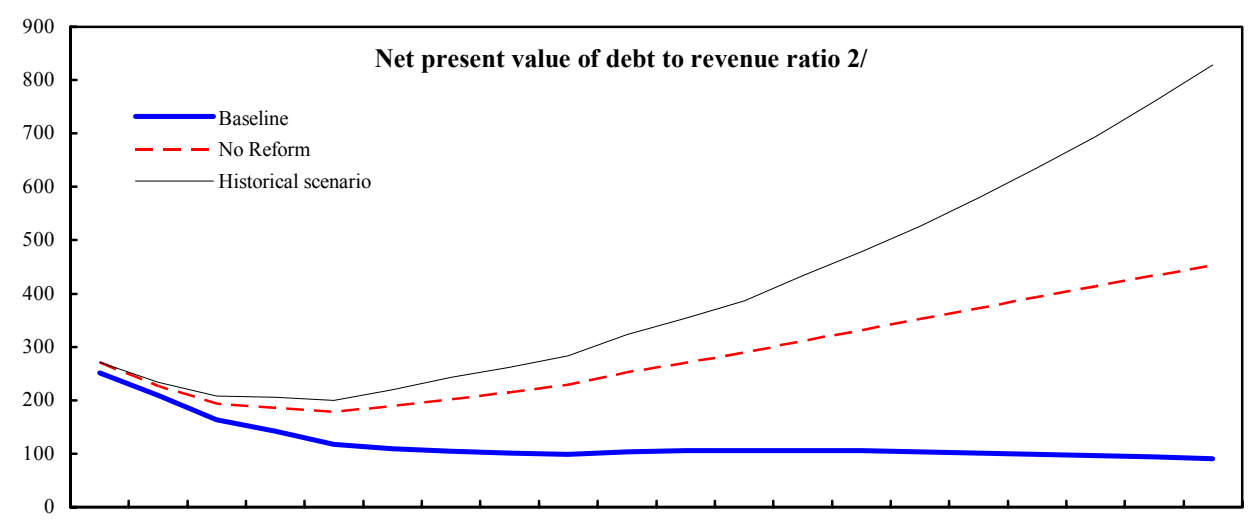

$20032004200520062007200820092010 \quad 20112012 \quad 2013 \quad 2014 \quad 20152016 \quad 2017 \quad 20182019202020212022$

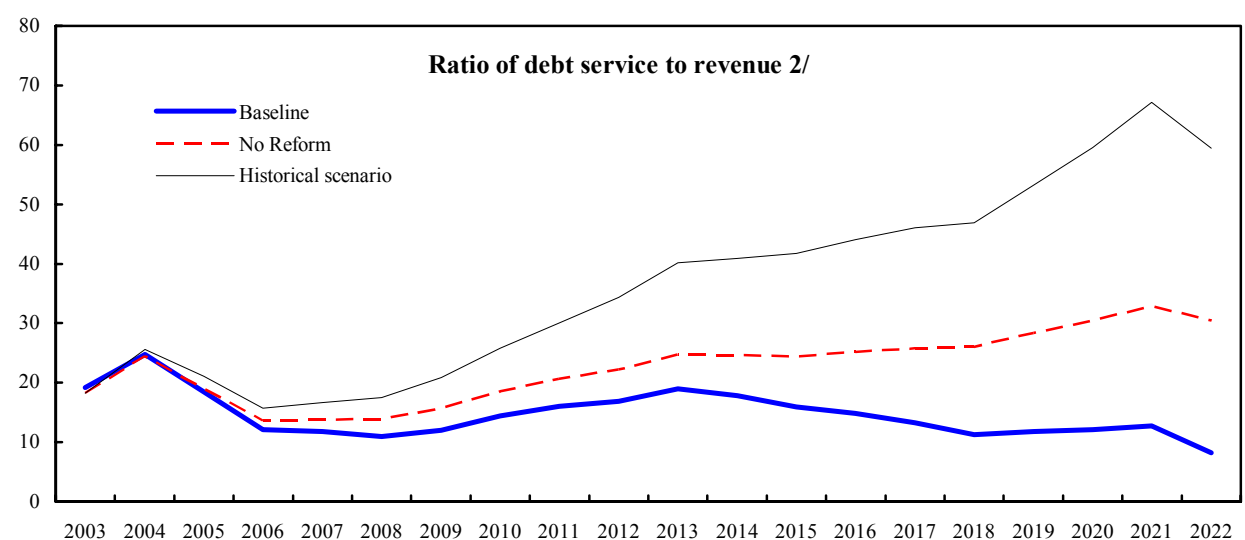

Source: Staff projections and simulations.

1/ Historical scenario is based on historic averages for real growth and primary balance during 1993-2002.

2/ Revenue includes grants but excludes domestic debt service. 
Figure II.4. Sierra Leone: Indicators of Public Debt Under Alternative Scenarios, 2003-22 1/

(In percent)

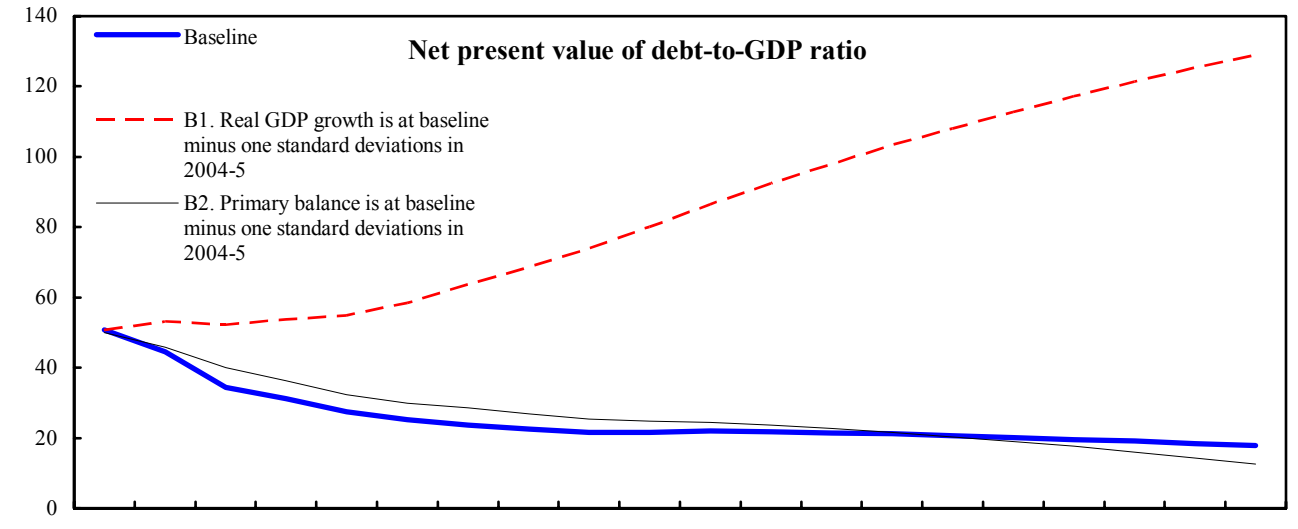

$2003200420052006200720082009201020112012 \quad 20132014 \quad 2015 \quad 2016 \quad 2017 \quad 20182019202020212022$

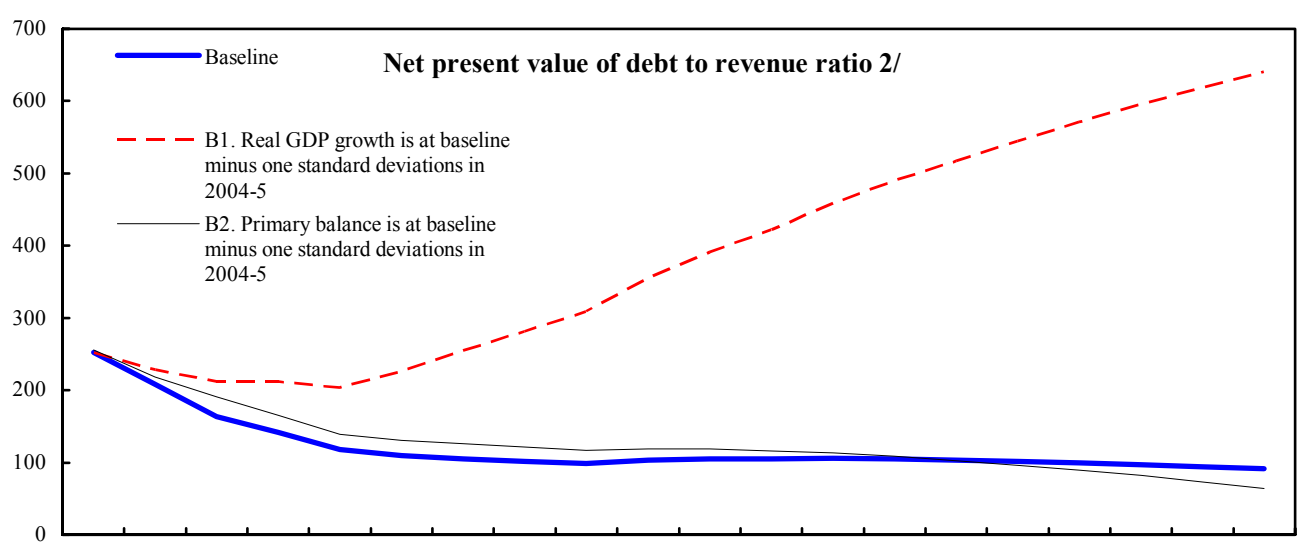

$2003200420052006200720082009201020112012 \quad 2013 \quad 201420152016201720182019202020212022$

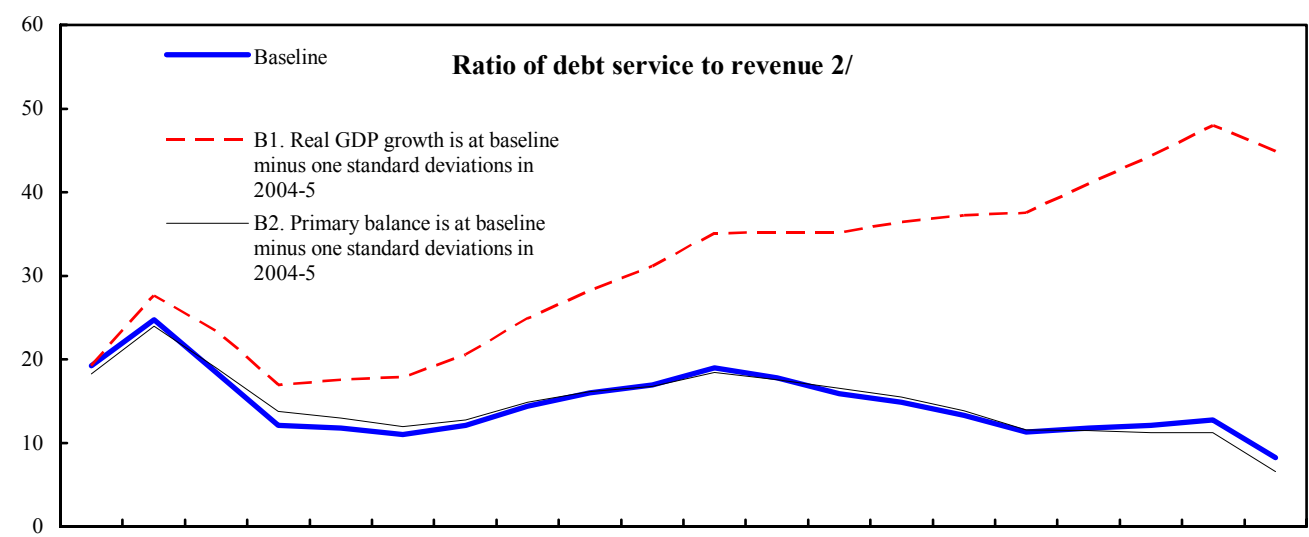

$2003200420052006200720082009201020112012 \quad 2013 \quad 20142015 \quad 20162017 \quad 20182019202020212022$

Source: Staff projections and simulations.

1/ Historical scenario is based on averages during 1993-2002.

2/ Revenue includes rants but excludes domestic debt service. 
Figure II.5. Sierra Leone: Indicators of Public Debt Under Alternative Scenarios, 2003-22 1/ (In percent)
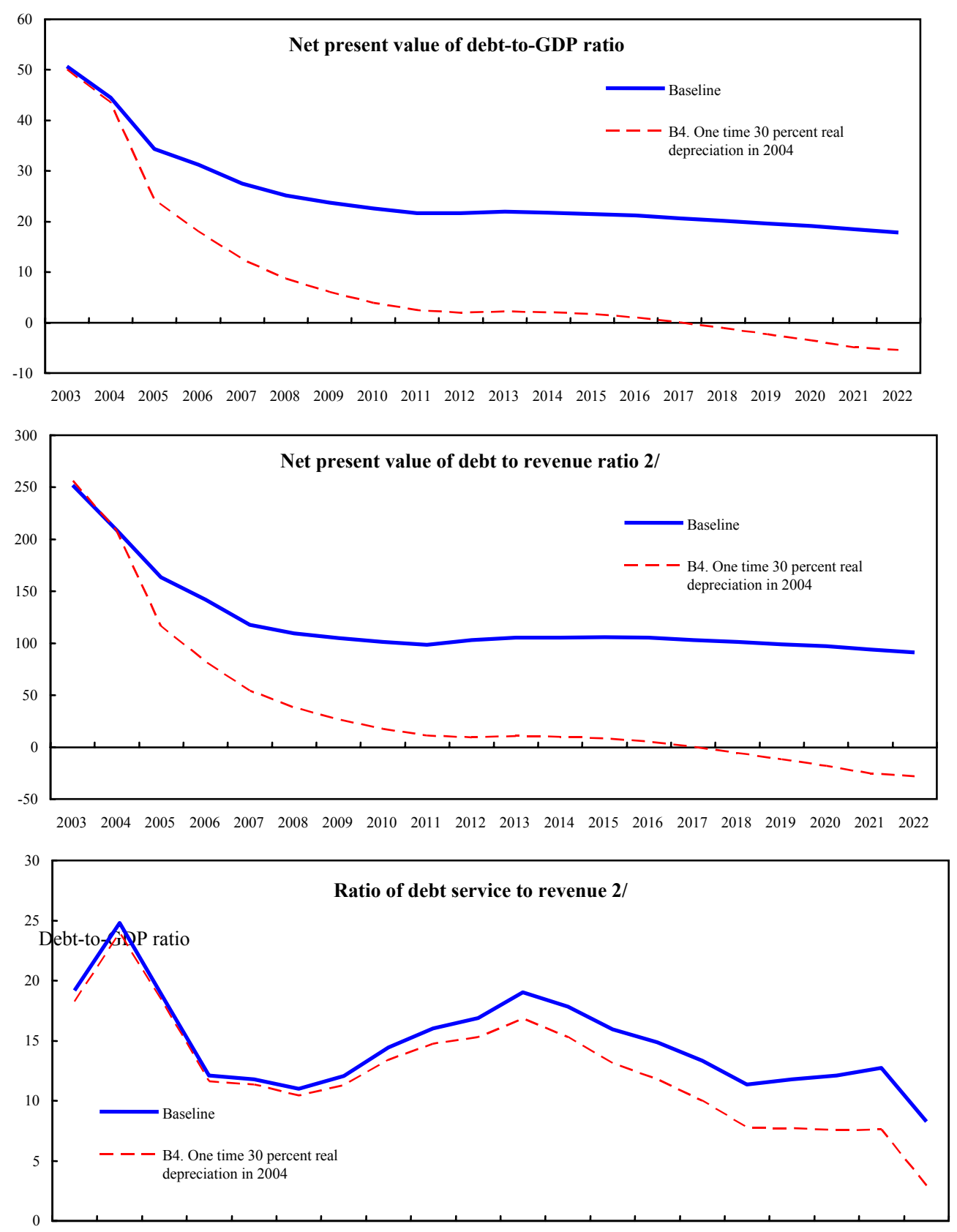

$\begin{array}{llllllllllllllllllll}2003 & 2004 & 2005 & 2006 & 2007 & 2008 & 2009 & 2010 & 2011 & 2012 & 2013 & 2014 & 2015 & 2016 & 2017 & 2018 & 2019 & 2020 & 2021 & 2022\end{array}$

Source: Staff projections and simulations.

1/ Historical scenario is based on averages during 1993-2002.

2/ Revenue includes rants but excludes domestic debt service. 
Table II.1. Sierra Leone: Public Sector Debt Sustainability Framework, Baseline Scenario, 2001-22

(In percent of GDP, unless otherwise indicated)

\begin{tabular}{|c|c|c|c|c|c|c|c|c|c|c|c|c|c|c|}
\hline & \multicolumn{2}{|c|}{ Actual } & \multirow[b]{2}{*}{$\begin{array}{l}\text { Historical } \\
\text { Average 5/ } \\
\end{array}$} & \multirow[b]{2}{*}{$\begin{array}{c}\text { Standard } \\
\text { Deviation 5/ }\end{array}$} & \multirow{2}{*}{$\begin{array}{c}\text { Estimate } \\
2003 \\
\end{array}$} & \multicolumn{9}{|c|}{ Projections } \\
\hline & 2001 & 2002 & & & & 2004 & 2005 & 2006 & 2007 & 2008 & $\begin{array}{l}\text { Average } \\
2003-08 \\
\end{array}$ & 2013 & 2022 & $\begin{array}{l}\text { Average } \\
2009-22 \\
\end{array}$ \\
\hline $\begin{array}{l}\text { Public sector debt } \mathbf{1} \text { / } \\
\text { Of which: foreign-currency denominated }\end{array}$ & $\begin{array}{l}79.7 \\
29.5\end{array}$ & $\begin{array}{l}72.3 \\
27.5\end{array}$ & $\begin{array}{l}180.4 \\
142.8\end{array}$ & $\begin{array}{l}73.7 \\
68.9\end{array}$ & $\begin{array}{l}76.3 \\
35.5\end{array}$ & $\begin{array}{l}73.9 \\
39.2\end{array}$ & $\begin{array}{l}77.3 \\
45.8\end{array}$ & $\begin{array}{l}78.0 \\
49.7\end{array}$ & $\begin{array}{l}76.3 \\
51.8\end{array}$ & $\begin{array}{l}76.9 \\
54.8\end{array}$ & $\begin{array}{r}76.5 \\
46.1\end{array}$ & $\begin{array}{l}76.8 \\
57.7\end{array}$ & $\begin{array}{l}65.9 \\
50.5\end{array}$ & $\begin{array}{l}73.7 \\
55.7\end{array}$ \\
\hline Change in public sector debt & -192.5 & -7.4 & -11.2 & 71.1 & 4.0 & -2.4 & 3.4 & 0.7 & -1.7 & 0.6 & 0.8 & -0.8 & -3.3 & -0.8 \\
\hline Identified debt-creating flows & 7.5 & -13.9 & -23.3 & 59.4 & -2.7 & -2.0 & -5.1 & -4.6 & -5.4 & -4.7 & -4.1 & -2.8 & -4.5 & -3.8 \\
\hline Primary deficit & 6.0 & 2.9 & 3.9 & 1.6 & 1.7 & 2.1 & 0.5 & 0.4 & -0.8 & -0.1 & 0.6 & 1.2 & -0.9 & 0.1 \\
\hline Revenue and grants & 18.9 & 20.4 & 14.3 & 4.6 & 20.1 & 21.3 & 21.0 & 22.0 & 23.4 & 23.0 & 21.8 & 20.8 & 19.6 & 20.6 \\
\hline Primary (noninterest) expenditure & 25.0 & 23.3 & 18.2 & 4.7 & 21.8 & 23.4 & 21.5 & 22.3 & 22.6 & 22.9 & 22.4 & 21.9 & 18.6 & 20.7 \\
\hline Automatic debt dynamics & 1.6 & -16.8 & -27.1 & 58.9 & -4.4 & -4.1 & -5.6 & -4.9 & -4.6 & -4.5 & -4.7 & -4.0 & -3.6 & -3.8 \\
\hline Contribution from interest rate or growth differential & -43.6 & -16.6 & -23.2 & 25.2 & -6.8 & -5.7 & -6.1 & -5.7 & -5.5 & -5.5 & -5.9 & -5.0 & -4.5 & -4.9 \\
\hline Of which: contribution from average real interest rate & -2.2 & 0.6 & -4.3 & 3.9 & -0.7 & -0.5 & 1.4 & 0.8 & 0.3 & -0.1 & 0.2 & -0.6 & -0.6 & -0.6 \\
\hline Of which : contribution from real GDP growth & -41.5 & -17.2 & 5.2 & 27.0 & -6.1 & -5.2 & -7.6 & -6.5 & -5.8 & -5.3 & -6.1 & -4.4 & -3.9 & -4.3 \\
\hline Contribution from real exchange rate depreciation & 45.3 & -0.2 & -3.9 & 43.9 & 2.4 & 1.6 & 0.6 & 0.8 & 0.9 & 0.9 & 1.2 & $\ldots$ & $\ldots$ & 1.0 \\
\hline Other identified debt-creating flows & -0.1 & 0.0 & -0.1 & 0.1 & 0.0 & 0.0 & 0.0 & 0.0 & 0.0 & 0.0 & 0.0 & 0.0 & 0.0 & 0.0 \\
\hline Privatization receipts (negative) & -0.1 & 0.0 & -0.1 & 0.1 & 0.0 & 0.0 & 0.0 & 0.0 & 0.0 & 0.0 & 0.0 & 0.0 & 0.0 & 0.0 \\
\hline Recognition of implicit or contingent liabilities & 0.0 & 0.0 & 0.0 & 0.0 & 0.0 & 0.0 & 0.0 & 0.0 & 0.0 & 0.0 & 0.0 & 0.0 & 0.0 & 0.0 \\
\hline Debt relief (HIPC and other) & 0.0 & 0.0 & 0.0 & 0.0 & 0.0 & 0.0 & 0.0 & 0.0 & 0.0 & 0.0 & 0.0 & 0.0 & 0.0 & 0.0 \\
\hline Other (specify; bank recapitalization) & 0.0 & 0.0 & 0.0 & 0.0 & 0.0 & 0.0 & 0.0 & 0.0 & 0.0 & 0.0 & 0.0 & 0.0 & 0.0 & 0.0 \\
\hline Net present value of public sector debt & 63.5 & 54.7 & 106.2 & 63.6 & 50.7 & 44.5 & 34.4 & 31.2 & 27.5 & 25.1 & 35.6 & 21.9 & 17.8 & 20.9 \\
\hline Of which: foreign-currency denominated & 13.3 & 10.0 & 68.5 & 57.4 & 9.8 & 9.8 & 2.9 & 2.9 & 3.0 & 3.0 & 5.2 & 2.8 & 2.4 & 2.8 \\
\hline Of which: external & 13.3 & 10.0 & 76.1 & 55.3 & 9.8 & 9.8 & 2.9 & 2.9 & 3.0 & 3.0 & 5.2 & 2.8 & 2.4 & 2.8 \\
\hline NPV of contingent liabilities (not included in public sector debt) & 0.0 & 0.0 & 0.0 & 0.0 & 0.0 & 0.0 & 0.0 & 0.0 & 0.0 & 0.0 & 0.0 & 0.0 & 0.0 & 0.0 \\
\hline Gross financing need $2 /$ & 33.3 & 20.4 & 18.9 & 8.1 & 20.5 & 22.0 & 18.1 & 16.8 & 14.6 & 13.2 & 17.5 & 15.0 & 12.0 & 13.7 \\
\hline NPV of public-sector-debt-to-revenue ratio (in percent) 3/ & 335.6 & 268.9 & 979.1 & 903.4 & 252.0 & 208.6 & 163.6 & 142.0 & 117.5 & 109.3 & 165.5 & 105.5 & 91.0 & 101.1 \\
\hline Of which: external & 70.3 & 49.1 & 731.8 & 661.7 & 48.9 & 45.8 & 13.8 & 13.3 & 12.8 & 13.1 & 24.6 & 13.6 & 12.5 & 13.5 \\
\hline Debt-service-to-revenue ratio (in percent) $3 / 4 /$ & 68.6 & 18.2 & 39.8 & 19.9 & 19.2 & 24.8 & 18.4 & 12.1 & 11.8 & 11.0 & 16.2 & 19.0 & 8.3 & 14.0 \\
\hline Primary deficit that stabilizes the debt-to-GDP ratio & 198.5 & 10.3 & 74.3 & 107.6 & -2.3 & 4.5 & -2.9 & -0.4 & 0.9 & -0.7 & -0.1 & 1.9 & 2.4 & 0.9 \\
\hline \multicolumn{15}{|l|}{ Key macroeconomic and fiscal assumptions } \\
\hline Real GDP growth (in percent) & 17.9 & 27.5 & -0.9 & 15.6 & 9.3 & 7.4 & 9.4 & 7.1 & 6.5 & 6.0 & 7.6 & 6.0 & 6.0 & 6.1 \\
\hline Average real interest rate on domestic currency debt (in percent) & 3.7 & 10.4 & -7.3 & 10.8 & -0.9 & -3.6 & 2.3 & 3.0 & 3.0 & 2.9 & 1.1 & 2.5 & 2.5 & 2.6 \\
\hline Real exchange rate depreciation (in percent; + indicates depreciation) & 30.1 & 6.9 & -0.4 & 24.2 & 9.8 & $\ldots$ & $\ldots$ & $\cdots$ & $\ldots$ & $\ldots$ & $\ldots$ & $\ldots$ & $\ldots$ & 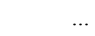 \\
\hline Inflation rate (GDP deflator, in percent) & 2.0 & -3.7 & 23.2 & 22.3 & 8.2 & 14.4 & 6.9 & 5.6 & 4.8 & 3.8 & 7.3 & 3.8 & 3.8 & 3.8 \\
\hline Growth of real primary spending (deflated by GDP deflator, in percent) & 13.4 & 10.2 & 4.3 & 30.2 & 2.4 & 19.9 & 4.3 & 13.8 & 9.0 & 8.1 & 9.6 & 3.1 & 4.9 & 4.0 \\
\hline Grant element of new external borrowing (in percent) & 56.9 & 46.0 & 10.3 & 21.9 & 48.0 & 47.1 & 42.4 & 46.5 & 43.5 & 40.8 & 44.7 & 56.9 & 56.9 & 56.9 \\
\hline
\end{tabular}

Sources: Country authorities; and Fund staff estimates and projections.

1/ Public sector comprises the central government or nonfinancial public sector. External debt is reported inclusive of unconditional HIPC debt relief.

2/ Gross financing need is defined as the primary deficit plus debt service plus the stock of short-term debt at the end of the last period.

$3 /$ Revenues includes grants.

She sum of interest and amortization of medium- and long-term deb.

5/ Historical averages and standard deviations are generally bsed on data for 1993-2002. 


\section{Rehabilitating SierRa Leone's Mining Sector-Challenges AND The Way FORWARD $^{25}$}

1. Sierra Leone faces challenges both in rehabilitating large-scale mining operations and in regulating artisanal mining activity. The challenges are quite different and require different policy responses, but in general the government of Sierra Leone has already made significant progress in developing a policy framework to address them. Fiscal policies for both large- and small-scale mining, for example, are already broadly appropriate and need only to be refined and applied. In large-scale mining, a major task will be to apply the general fiscal policies, which means breaking with the previous practice of reaching special agreements with individual investors that, in some cases, deviate significantly from the general regime. Implementation of the Extractive Industries Transparency Initiative (EITI), under which all revenue flows from the mining sector are published, will also help to increase transparency and reduce governance concerns. In artisanal mining, the government's main concern is to eliminate the incentives for smuggling. Besides improving administrative and law enforcement ability it will also need to adopt a more holistic approach that aims to create an environment where local communities and diggers and miners benefit more from the country's mineral wealth. Increasing transparency in the domestic diamond trade will be a key step in this endeavor.

\section{A. Background}

2. Sierra Leone has a rich and diverse mineral resource base, and mining is vital to its economy. The mineral sector can be divided into three sub sectors: large-scale production of the non precious minerals rutile (titanium dioxide and a little iron) and bauxite; large-scale production of diamonds; and artisanal and small-scale production of precious mineralsmainly diamonds and to a much lesser extent, gold.

Table 1. Export Trends in Sierra Leone (In percent of GDP)

\begin{tabular}{crrr}
\hline & 1991 & $19941 /$ & 2003 \\
\hline Total exports & 24 & 22 & 15 \\
Of which: rutile & 9 & 6 & 0 \\
$\quad$ bauxite & 3 & 2 & 0 \\
$\quad$ officially recorded diamond exports & 4 & 3 & 8 \\
estimates of unrecorded diamond exports & 4 & 8 & 5 \\
\hline
\end{tabular}

1/ The year before the war forced the closure of major mining operations.

${ }^{25}$ Prepared by Jan Gottschalk. 
3. Large-scale production of nonprecious minerals. Prior to the war, which began in 1991 and lasted until 2001, the Sierra Rutile Mine produced over 25 percent of the world's rutile from one of the world's highest-grade deposits. Work interruptions caused by the war led, in 1995, to the closure of the mine. In 1994, the last full year of production, the rutile mine generated about US\$60 million in exports, corresponding to a third of that year's exports. To reopen the mine, the government entered into an agreement with an investor in 2001; the agreement was modified in 2003. Production is expected to resume in 2005. Sierra Leone's other major non-precious mineral is bauxite. Until the Mokanji Bauxite Mine was closed in 1995 on account of the war, it produced, together with neighboring deposits, a specialty bauxite with little organic material. Bauxite exports in 1994 totaled about US\$16 million. Negotiations on the terms for rehabilitating the bauxite mine are currently under way, and, if they are concluded successfully, production could also restart in 2005.

4. Large-scale production of diamonds. Sierra Leone has two known kimberlite diamond deposits, the Koidu and Tongo Fields. Diamonds found in kimberlite deposits can be mined by large-scale corporate operations. In 1995, the government entered in 1995 into an agreement with an investor to develop the Koidu Kimberlite Project. After an investment of US\$18 million, the mine was scheduled to begin operations in 1997 but was forced to close in the same year because of the war. The investment was lost. Additional shareholders were brought in, and, after another investment of US\$18 million, production resumed in late 2003.

5. Artisanal production of diamonds. Since the discovery of the first alluvial diamond deposits in Sierra Leone in the 1930s, diamond operations have largely been controlled by a single company that guarded the mining fields and had the resources to employ heavy equipment. ${ }^{26}{ }^{27}$ But during the 1970s and 1980s the Sierra Leone diamond industry fell prey to corruption and mismanagement, with the result that many of the country's diamonds were exported illegally. Eventually, diamond mining was opened to artisanal, or small-scale, miners. ${ }^{28}$ Between 1992 and 2000, average official exports were less than 200,000 carats-

${ }^{26}$ Alluvial deposits are spread out over large areas, while kimberlite deposits are concentrated in one area.

${ }^{27}$ Commercially available diamonds were discovered in Sierra Leone in the early 1930s. In 1935 the British colonial authorities granted exclusive mining and prospective rights to Sierra Leone Selection Trust (SLST) and by 1937 Sierra Leone was mining one million carats annually. Production reached its peak of 2 million carats annually in the 1960s.

${ }^{28}$ Since the extraction of diamonds from alluvial deposits is a relatively simple process, illegal diamond mining and diamond smuggling was a source of concern already in the 1950s. Control mechanisms instituted by the single company-first the SLST and later the state-owned National Diamond Mining Company (NDMC) - mitigated the problem. But the 
just one-tenth of official exports in the peak years during the late 1960s — and the per carat value was significantly less than the country's historical average. Not only was the bulk of the country's diamonds being smuggled out, but they also became an impetus for war: the Kongo and Tongo Fields, the richest diamonds mines in the country, became primary targets for the rebel movement, the Revolutionary United Front (RUF), which relied on diamond mining as a major source of fund-raising activities. In 2000, the UN Security Council responded by imposing an embargo on the direct and indirect import of rough diamonds from Sierra Leone until a new mining, export, and monitoring regime could be developed. A certification system was put in place in October 2000, with technical assistance from Belgium's Diamond High Council and financial assistance from the United Kingdom and the United States. In order to ensure effectiveness of the certification system, the Kimberley Process, a standardized global certification scheme, was implemented simultaneously in more than 50 countries in January 2003. This contributed to an increase in officially recorded diamond exports from 350,000 carats in 2002 to about 500,000 carats in 2003.

\section{B. Restarting Large-Scale Mining Operations}

\section{Attracting Investment Without Eroding the Revenue Base}

6. Facilitating the restart of large-scale mining operations poses a difficult challenge for the government of Sierra Leone in that it has to balance the demand for suitable incentives with the need to preserve the tax revenue potential of the mining sector. Rehabilitating the equipment needed for large-scale mining operations requires substantial investments, but investors are likely to be wary of such investments given the large losses they suffered during war years. Fiscal incentives might also be necessary to compensate for the poor state of the infrastructure and to address the remaining governance concerns. Generous tax incentives, however, imply that a smaller share of the rents generated by Sierra Leone's mineral wealth accrues to the government.

7. The trade-off between facilitating investment and forgoing revenue should be governed by the overall fiscal regime, which in Sierra Leone has a solid foundation. A recent review of Sierra Leone's fiscal regime for the mineral sector by the staff did not find fundamental weaknesses. The fiscal regime is regulated by the Mines and Minerals Act of 1996 and the Income Tax Act of 2000. The Mines and Minerals Act set royalties at 5 percent for precious stones, 4 percent for precious metals and 3 percent for all other minerals. In international comparisons, Sierra Leone's royalty rate is on the low side for diamonds but probably high for other minerals. The income tax on mining companies is 30 percent, which is moderate by international standards; as to import duty, the Income Tax Act grants mining companies duty-free importation of machinery and equipment for prospecting and

mechanism eroded in the 1970s and 1980s and were eventually abandoned when mining was opened to artisanal miners. The NDMC was closed shortly thereafter. 
exploration. In sum, the fiscal regime imposes a moderate tax burden on the mining sector and is reasonably free of targeted tax incentives.

8. In practice, however, the legislated general regime has been overridden by special agreements. In fact, on each occasion that an investor has applied for a mining lease, that investor has sought and received a special agreement incorporating specific fiscal terms for the project. As a result, the fiscal regimes for all three large-scale mining operations (rutile, kimberlite, and bauxite) are regulated by special agreements. ${ }^{29}$ Negotiating a special agreement holds two advantages for mining investors: first, the terms may be more generous than those envisioned under the general regime, and, second, special agreements typically contain fiscal stability provisions that prevent the government from unilaterally changing their terms. For the government, however, this practice undermines the general fiscal regime and opens the door to discretionary decisions, which may lead to revenue losses, inequitable treatment of investors, and governance concerns.

9. Special agreements that give investors equity stakes in mining operations have been a source of concern for stakeholders in the mining sector in the recent past. The government agreed in 2003 to a modification of the prevailing agreement with the investor in the rutile mine by signing a memorandum of understanding that granted the investor significant tax concessions in return for an equity stake. ${ }^{30}$ The government, believing the new fiscal terms were necessary to ensure that the rehabilitation of the country's major mine would go forward asked for the equity share as a way to benefit in any favorable developments in the project. However, a number of stakeholders in the mining sector objected to government equity participation - even a non-operating interest - because they had had a bad experience with previous state-run enterprises in this sector. They also objected on the grounds that participation by the government was inconsistent with its privatization and divesture policy. In addition, such equity stakes raise complex valuation issues and may give rise to governance concerns. Responding to these concerns, the government clarified that acquiring

\footnotetext{
${ }^{29}$ The rutile agreement was recently renegotiated — and the Government improved the terms significantly relative to the general fiscal regime - to facilitate the resumption of rutile exports; the rehabilitation of the kimberlite mine in the Koidu Field was based on the existing agreement from 1995, which is broadly comparable to the general regime; negotiations on the terms for the resumption of bauxite mining are under way.

${ }^{30}$ Under the terms of the memorandum, the government grants a tax holiday through 2014 for some taxes, including the corporate income tax, and reduces the tax rate for others, including on royalties. In return, the government may purchase up to 30 percent of equity, with payment coming from forgone tax revenue.
} 
an equity stake in the rutile mine was a one-off decision and that it would not seek further equity stakes in lieu of dues, taxes, and fees. ${ }^{31}$

\section{Refining and applying the fiscal regime}

10. The existing fiscal regime provides a good starting point for rehabilitating the mining sector, but further refinements may be needed to meet the government's objectives. The government has made substantial progress in outlining its objectives by formulating, in consultation with stakeholders, its Core Mineral Policy. This policy states that the government's objective is to stimulate investment in the mineral sector by promoting private sector participation, which is to be achieved through the establishment of a favorable environment, in which geo-information and regulations area adequate, the institutional capacity for the processing of investments is satisfactory, and the fiscal conditions are attractive. To make fiscal conditions attractive, the government plans to review and put in place an investor-friendly legal and institutional framework, which is to include a progressive and predictable tax regime. As a next step, the government will review the Mines and Mineral Act of 1996 and relevant income tax legislation to make it consistent with these objectives and will develop implementing regulations.

11. Any review of the existing fiscal regime will have to address the question of how relevant the general regime has been, given that every investor has negotiated a special agreement. Since Sierra Leone has recently emerged from a serious conflict period and political instability, it is probably inevitable that investors will seek special agreements with assurances of fiscal stability and the best terms possible. A revised fiscal regime will probably have to accommodate investor concerns, but ensure at the same time that the agreements are consistent with the general regime. The government should consider a number of issues.

12. Providing fiscal stability. The existing general legislation does not contain provisions assuring investors of fiscal or wider legislative stability. Including such provisions in revised legislation could increase investor confidence. Those in special agreements, which probably remain inevitable, could reference the provisions in the general legislation, thereby contributing to a more uniform treatment of investors. As a general principle, the scope of stability provisions should be limited to fiscal imposts. The provisions should also be symmetrical: the investor should receive indemnity of exemption from increases but should not benefit from decreases.

${ }^{31}$ A different situation applies, however, to so-called free equity, in which the government receives an equity stake for free, but does not assume any financial obligations or have any management involvement. In fact, free equity can be seen as equivalent to a tax on dividends at the percentage rate of the equity holding. A mining company may offer free equity to the government to allow it to benefit if the project succeeds, thereby heading off demands for more far-reaching changes to the fiscal terms. 
13. Limiting discretion. To prevent a situation where the fiscal terms in special agreements have little resemblance to the general fiscal regime, it would help to incorporate all fiscal provisions into the relevant fiscal legislation and to limit fiscal provisions in special agreements and in the Mines and Minerals Act to cross-referencing the fiscal legislation. The legal status of special agreements should also be clarified to ensure that these are subsidiary to relevant fiscal legislation and the Mines and Minerals Act. Finally, it might be helpful to develop model agreements, which have proved useful in the petroleum sector.

14. Clarifying the power to make agreements. The Mines and Minerals Act should be amended to provide a clear power for concluding mining agreements. The current situation gives rise to some uncertainty, which might have contributed to investor demands to give special agreements the status of law. ${ }^{32}$

15. Enhancing transparency. The revenues derived from mineral extraction should be made public to address widespread governance concerns in Sierra Leone. The government has taken an important step in this direction by expressing its interest to the World Bank in participating in the Extractive Industries Transparency Initiative (EITI). The basic principle of the EITI requires the government to publish its receipts of mineral resource revenues and the mineral companies to report their payments to the government. In principle, there is no reason to expect any differences between the reported transactions. If there are differences, they should be reconciled clearly and consistently.

\section{Regularizing Artisanal Mining Activity}

\section{The challenge of eliminating the incentives for smuggling}

16. The objectives in reducing smuggling and regularizing artisanal mining activity are to (i) restore government control, law and order, and government services to the artisanal mining areas; ${ }^{33}$ (ii) increase transparency in the diamond trade so that local communities, miners, and diggers can benefit more from the country's diamond wealth; and (iii) increase tax collection. Currently, smuggling is pervasive: a recent survey of diamond mining in Sierra Leone, which relied on air patrols and on-site visits, concluded that about 55 percent

\footnotetext{
${ }^{32}$ As a result of these demands, Sierra Leone's parliament ratified previous agreements and gave them the status of law.

${ }^{33}$ During the war, the government effectively lost control over these areas. The continued existence of a large illegal mining sector complicates the rebuilding of government institutions in the mining areas.
} 
of the total significant mining operations in Sierra Leone were operating illegally in $2003 .{ }^{34}$

${ }^{35}$ The challenge is that the incentives to smuggle are inherent in artisanal mining.

17. The incentives for smuggling are inherently greater in artisanal mining than in kimberlite (large-scale) mining for two reasons ${ }^{36}$ : artisanal mining typically takes place in large, insecure regions that are difficult to control, and artisanal mining is often associated with limited competition between diamond buyers because of barriers to entry and implicit contracts, giving rise to uncompetitive domestic prices and, thus, increasing the benefits of smuggling. 37

18. Implicit contracts contribute to both smuggling and the lack of transparency in the domestic diamond trade. Implicit contracting typically occurs because artisanal miners have irregular earnings and therefore need financing to insure themselves against bad times. ${ }^{38}$ Since they are typically unable to borrow through the conventional banking system, their financing needs are often met by diamond dealers, who pay them in advance in return for the

${ }^{34}$ Sierra Leone Diamond Mining Survey Report, United Nations Mission in Sierra Leone.

${ }^{35}$ The output share of illegal mining in total artisanal diamond production, though, is likely to be lower, because 50 percent of the mining operations that use heavy equipment are operating legally. Also, those mines that were found to be operating illegally do so to varying degrees: some were found to be registered but did not have the license on site; others were operating without a licensed manager, and some were operating without any form of license.

${ }^{36}$ Oomes, Nienke and Vocke, Matthias, 2003, Diamond Smuggling and Taxation in subSaharan Africa, IMF Working Paper 03/167 (Washington: International Monetary Fund).

${ }^{37}$ In Sierra Leone, barriers to entry exist because outsiders often do not understand the intricacies of the domestic trading system (which depends on paid informants who scout the alluvial mining areas for interesting goods and lure miners to specific offices), and local traders often exploit the lack of experience of those they see as short-term players. See Sierra Leone Diamond Sector Financial Policy Constraints, prepared by Management Systems International Under USAID Cooperative Agreement.

${ }^{38}$ In Sierra Leone, the key players in artisanal mining of alluvial diamonds are diggers, holders of mining licenses (generally referred to as miners), licensed dealers (and their agents), and licensed exporters. Diggers are usually unskilled workers who work for miners, who, in turn, provide them with food and tools. The dealers and their agents buy diamonds from the miners and sell them to the exporters at prices that they negotiate on a case-by-case basis. The dealers usually provide funding to the miners and receive funding from the exporters. For an in-depth discussion, see Sierra Leone: Tapping the Mineral Wealth for Human Progress - A Break with the Past. World Bank Report. 
exclusive right to buy their diamonds. Diamond dealers, in turn, often have similar implicit contracts with exporters. Implicit contracting gives rise to smuggling through two channels:

- Implicit contracts limit competition and allow export companies to purchase diamonds at prices below the international market price, creating incentives to smuggle.

- $\quad$ Partners in implicit contracts smuggle to avoid their contractual obligations. It is lucrative for a dealer, for example, to smuggle a valuable stone outside the country and obtain a higher price for it than implied by the implicit contract with an exporter. Likewise, an exporter has incentives to bypass official sale channels to hide the true value of the stones he is exporting, which allows him to undervalue them and thereby reduce the price he pays the dealer. The latter case is likely to be more prevalent than the former, since exporters are better positioned to assess the true value of a stone and smuggle it outside the country. One side effect of such operations is that the domestic diamond trade becomes nontransparent.

19. The lack of transparency in the domestic diamond trade is in itself a source of concern. Nontransparent pricing allows exporters to underpay dealers and, by extension miners and diggers. The bulk of the rents generated by Sierra Leone's diamond wealth thus accrues to a small circle of people, and most of it probably leaves the country when the diamonds are smuggled to and sold in foreign diamond centers like Antwerpen, Belgium. According to some estimates, local expenditures associated with the annual production (inputs) are not more than 10 percent -15 percent of the diamond output value. ${ }^{39}$ In an extreme case, dealers, miners, and diggers capture none of the rents, and around 80 percent of the diamond value accrues in rents to domestic exporters and foreign diamond traders. ${ }^{40}$

\section{Empowering local mining communities}

20. The general fiscal regime for artisanal mining is broadly appropriate since the implementation of reforms in the early 1990s, including a low export tax (3 percent) to encourage the regularization of the diamond trade through official channels and a liberal foreign exchange regime. No other turnover or profit taxes are levied other than a standard

${ }^{39}$ Sierra Leone Diamond Sector Financial Policy Constraints, prepared by Management Systems International Under USAID Cooperative Agreement.

${ }^{40}$ World Bank estimates, though, suggest that per capita returns to artisanal miners in Sierra Leone are low not because of the share of rewards they receive as a group, but primarily because their numbers are large and productivity is low. For a detailed discussion, see Sierra Leone: Tapping the Mineral Wealth for Human Progress - A Break with the Past. World Bank Report No. xxx. 
income tax. With the cost of smuggling generally estimated at 2-3 percent of revenues, taxes in Sierra Leone are not a major impediment to legal exports.

21. However, the government is unable to enforce the fiscal regime or, more generally, property rights and mining regulations in the diamond regions. The United Nations Mission in Sierra Leone found in a recent mining survey that the government - in particular, the Ministry of Mineral Resources and the police, need more training to be able to address illicit mining and smuggling activities satisfactorily. ${ }^{41}$ The government, with assistance from the World Bank, is currently installing a mining cadastre based on GIS and GPS that will help define property rights and thereby provide the basis for the enforcement of mineral rights. Secure property rights and a better prepared government agencies will go a long way toward bringing the mining sector back under the government's control and restoring law and order.

22. Enabling local communities to benefit more from mining operations in their region will require, however, an approach that goes beyond the enforcement of laws and regulations. Currently, local communities receive 0.75 percentage points from the 3 percent export tax, which is enhanced by some local taxes (for example, a residence tax) on mining activity. the government and the mining industry acknowledge that local communities do not receive a proportionate share of diamond revenues. The government is addressing this inequity, in part, by establishing of the Diamond Area Community Development Fund, which provides a mechanism to channel a portion of the total diamond revenues to local communities. These additional funds also increase the incentives for local communities to help regularize illegal mining activity.

23. The government could:

- $\quad$ Empower local miners and diggers through various means, including by:

- $\quad$ leveling the playing field through training to improve their ability to evaluate products;

- $\quad$ providing information on available production and marketing facilities;

- $\quad$ helping artisanal miners establish a business for the rental or lease of equipment so they can fund their mining operations;

- $\quad$ providing extension services to artisanal miners;

- $\quad$ promoting the formation of associations for small-scale miners; and.

${ }^{41}$ Sierra Leone Diamond Mining Survey Report, United Nations Mission in Sierra Leone. 
- $\quad$ addressing bottlenecks in the banking system so that foreign currency transferred for diamond trade transactions is available immediately, which would minimize recourse to the parallel market for foreign exchange and increase incentives to use the banking system.

24. Many of these measures are designed to enhance transparency in the diamond sector, thereby weakening the rationale for smuggling and ensuring that miners and diggers receive fair prices. Another ongoing effort entails organizing miners into cooperatives, training them, and providing funding to mechanize some operations. The government has already committed itself to these and other measures in its Core Mineral Policy.

25. An important step in the implementation of these measures is the Peace Diamond Alliance, which was launched in August 2003. Its purpose is to demonstrate, in Kono District, that an alluvial diamond industry can

- $\quad$ have a transparent, fair, and safe local market;

- $\quad$ maximize benefits to local miners, diggers, and their communities;

- $\quad$ track diamonds from the ground to export;

- $\quad$ minimize corruption; and

- $\quad$ mobilize local surveillance and monitoring of mines.

- The alliance brings together international, national, and local stakeholders. ${ }^{42}$ It is managed by an executive committee, comprising representatives from the mining industry, the government, and local communities. The executive committee serves as a local forum for the discussion of diamond management issues. Alliance members may provide funding for a credit scheme for miners; buy diamonds that are certified by the alliance to be sold as fair trade diamonds; miners and diggers on the value of their production; and develop diamond resource-use maps.

\footnotetext{
${ }^{42}$ Members include the Government of Sierra Leone, the United States Agency for International Development (USAID), the United Kingdom's Department for International Development (DfID), the United Nations, and key Sierra Leonean and international business and non-governmental organizations.
} 
Sierra Leone: Basic Data

Area, population, and GDP per capita

Area

Population

Total (2003)

Annual growth rate

Real per capita GDP (2004)
72,326 square kilometers

4.8 million

2.6 percent

US\$ 135

\begin{tabular}{|c|c|c|c|c|c|}
\hline & $\begin{array}{c}1999 \\
\text { Act. }\end{array}$ & $\begin{array}{c}2000 \\
\text { Act. }\end{array}$ & $\begin{array}{r}2001 \\
\text { Act. }\end{array}$ & $\begin{array}{r}2002 \\
\text { Est. }\end{array}$ & $\begin{array}{r}2003 \\
\text { Est. } \\
\end{array}$ \\
\hline & \multicolumn{5}{|c|}{ (Annual percentage change, unless otherwise indicated) } \\
\hline \multicolumn{6}{|l|}{ Income and expenditure } \\
\hline Real GDP 1/ & -8.1 & 3.8 & 17.9 & 27.5 & 9.3 \\
\hline Nominal GDP & 14.9 & 10.2 & 20.3 & 22.8 & 18.3 \\
\hline Consumer prices (end of period) & 36.7 & -2.7 & 3.4 & -3.1 & 11.3 \\
\hline Consumer prices (annual average) & 34.1 & -0.9 & 2.6 & -3.7 & 8.2 \\
\hline \multicolumn{6}{|l|}{ Money and credit } \\
\hline Broad money (including foreign currency deposits) & 40.8 & 9.7 & 33.7 & 30.1 & 23.9 \\
\hline Velocity (GDP/broad money) & 6.1 & 6.1 & 5.5 & 5.2 & 5.0 \\
\hline Domestic credit $2 /$ & 56.2 & -11.8 & 22.5 & 7.9 & 40.6 \\
\hline Reserve money & 39.0 & 9.2 & 29.4 & 24.9 & 22.4 \\
\hline Treasury bill rates (end of period; in percent) & 34.7 & 20.0 & 14.7 & 15.0 & 20.2 \\
\hline \multicolumn{6}{|l|}{ External sector } \\
\hline Exports (in U.S. dollars) & -5.7 & 22.3 & 6.1 & 48.9 & 27.4 \\
\hline Imports (in U.S. dollars) & -19.9 & 100.3 & 20.6 & 54.4 & 15.6 \\
\hline Terms of trade (- deterioration) & -4.9 & -9.0 & 1.7 & 0.0 & -0.1 \\
\hline \multirow[t]{2}{*}{ Real effective exchange rate (- depreciation; end of period) } & 2.1 & 32.1 & -15.3 & -9.7 & -17.2 \\
\hline & \multicolumn{5}{|c|}{ (In percent of GDP) } \\
\hline Gross domestic investment & 0.3 & 8.0 & 7.6 & 10.1 & 14.3 \\
\hline Gross national saving & -2.5 & -1.8 & -9.9 & 5.3 & 6.7 \\
\hline Gross domestic saving & -5.7 & -8.1 & -10.0 & -9.4 & -7.1 \\
\hline Current account balance, including official transfers & -2.8 & -9.8 & -17.4 & -4.8 & -7.6 \\
\hline Current account balance, excluding official transfers & -8.0 & -18.1 & -22.0 & -12.1 & -14.1 \\
\hline Goods and nonfactor services (net) & -6.0 & -16.1 & -19.6 & -19.5 & -21.3 \\
\hline Overall balance of payments & -5.7 & 0.4 & 1.7 & -0.3 & -4.6 \\
\hline Government domestic revenue & 7.1 & 11.4 & 13.0 & 12.1 & 12.4 \\
\hline Total expenditure and net lending & 22.0 & 28.7 & 29.5 & 28.6 & 26.9 \\
\hline Of which: current expenditure & 19.5 & 22.7 & 24.8 & 24.2 & 22.1 \\
\hline \multicolumn{6}{|l|}{ Overall fiscal balance } \\
\hline (commitment basis, excluding grants) & -14.9 & -17.3 & -16.5 & -16.5 & -14.5 \\
\hline (commitment basis, including grants) & -9.5 & -9.3 & -10.6 & -8.3 & -6.7 \\
\hline Domestic primary fiscal balance 3 / & -5.5 & -5.5 & -7.7 & -7.0 & -5.6 \\
\hline \multirow[t]{2}{*}{ Domestic financing } & 7.4 & 0.1 & 3.2 & 0.9 & 4.3 \\
\hline & \multicolumn{5}{|c|}{ (In percent of exports of goods and nonfactor services) } \\
\hline Debt service due (incl. to the Fund) after debt relief 4/ & 58.3 & 48.1 & 73.0 & 9.3 & 7.3 \\
\hline Debt service due (incl. to the Fund) before debt relief & 18.0 & 48.1 & 86.0 & 52.7 & 48.1 \\
\hline \multirow[t]{2}{*}{ Net present value of debt-to-exports ratio } & $\cdots$ & 136.3 & 150.6 & 162.3 & 153.6 \\
\hline & \multicolumn{5}{|c|}{ (In millions of U.S. dollars, unless otherwise indicated) } \\
\hline \multicolumn{6}{|l|}{ Memorandum items: } \\
\hline \multicolumn{6}{|l|}{ External current account balance, excluding } \\
\hline official transfers & -99.0 & -142.6 & -165.0 & -113.6 & -139.7 \\
\hline Gross international reserves & 38.3 & 49.6 & 51.9 & 84.6 & 59.4 \\
\hline (in months of imports of goods and services) & 1.8 & 2.2 & 1.9 & 2.5 & 1.5 \\
\hline GDP (in billions of leones) & $1,207.7$ & $1,330.3$ & $1,600.2$ & $1,965.2$ & $2,324.3$ \\
\hline GDP (in millions of U.S. dollars) & 663.8 & 633.8 & 805.6 & 936.2 & 989.9 \\
\hline
\end{tabular}

Sources: Sierra Leonean authorities; and IMF staff estimates and projections.

1/ Data reflect revisions in the national accounts.

2/ Changes as a percentage of beginning-of-period money stock (including foreign currency deposits).

3/ Domestic revenue minus total expenditure and net lending, excluding interest payments, and externally financed capital expenditure and disarmament, demobilization, and reintegration (DDR) program.

4/ As a percentage of exports of goods and services; after Naples (2001) and Cologne flow reschedulings (2002-04), and delivery of possible HIPC Initiative assistance. 
Table 1. Sierra Leone: Production of Major Agricultural Commodities, 1998-2003

\begin{tabular}{|c|c|c|c|c|c|c|}
\hline & 1998 & 1999 & 2000 & 2001 & 2002 & 2003 \\
\hline & \multicolumn{6}{|c|}{ (In thousands of metric tons) } \\
\hline \multicolumn{7}{|l|}{ Cereals } \\
\hline Rice (paddy) & 460.7 & 529.8 & 248.2 & 310.6 & 422.1 & $\ldots$ \\
\hline Maize & 10.5 & 12.1 & 8.6 & 10.0 & 13.1 & $\ldots$ \\
\hline Millet & 24.3 & 28.0 & 4.7 & 8.8 & 17.5 & $\ldots$ \\
\hline Sorghum & 24.1 & 27.7 & 5.5 & 15.5 & 31.0 & $\ldots$ \\
\hline Beniseed & 3.3 & 3.8 & 4.1 & $\ldots$ & $\ldots$ & $\ldots$ \\
\hline Other cereals & 0.0 & 0.0 & 0.0 & 0.0 & 0.0 & 0.0 \\
\hline \multicolumn{7}{|l|}{ Roots and tubers } \\
\hline Cassava & 346.6 & 398.6 & 240.0 & 314.4 & 399.7 & $\ldots$ \\
\hline Sweet potato & 56.3 & 64.8 & 20.0 & 21.2 & 25.5 & $\ldots$ \\
\hline Cocoyam & 1.3 & $\ldots$ & $\ldots$ & $\ldots$ & $\ldots$ & $\ldots$ \\
\hline Ginger & $\ldots$ & $\ldots$ & $\ldots$ & $\ldots$ & $\ldots$ & $\ldots$ \\
\hline Groundnuts & 42.5 & 48.9 & 29.0 & 48.9 & 98.4 & $\ldots$ \\
\hline \multicolumn{7}{|l|}{ Tree crops } \\
\hline Coffee & 34.4 & 39.6 & $\ldots$ & 74.9 & 520.0 & 545.0 \\
\hline Cocoa & 14.6 & 16.8 & $\ldots$ & 568.8 & 342.2 & $2,752.7$ \\
\hline Palm kernels & 13.9 & $\ldots$ & $\ldots$ & $\ldots$ & $\ldots$ & $\ldots$ \\
\hline Kola nuts & $\ldots$ & $\ldots$ & $\ldots$ & $\ldots$ & $\ldots$ & $\ldots$ \\
\hline \multirow[t]{2}{*}{ Palm oil } & 56.9 & 65.4 & $\cdots$ & $\cdots$ & $\cdots$ & $\cdots$ \\
\hline & \multicolumn{6}{|c|}{ (Annual percentage change) } \\
\hline Rice (paddy) & 12.0 & 15.0 & -53.2 & 25.1 & 35.9 & $\ldots$ \\
\hline Cassava & 12.0 & 15.0 & -39.8 & 31.0 & 27.1 & $\ldots$ \\
\hline Sweet potato & 11.9 & 15.1 & -69.1 & 6.1 & 20.0 & $\ldots$ \\
\hline Coffee & 12.1 & 15.1 & $\ldots$ & $\ldots$ & 594.3 & 4.8 \\
\hline Cocoa & 12.3 & 15.1 & $\ldots$ & $\ldots$ & -39.8 & 704.4 \\
\hline Palm kernels & 1.5 & $\ldots$ & $\ldots$ & $\ldots$ & $\ldots$ & $\ldots$ \\
\hline Kola nuts & $\ldots$ & $\ldots$ & $\ldots$ & $\ldots$ & $\ldots$ & $\ldots$ \\
\hline Palm oil & 12.0 & 14.9 & $\ldots$ & $\ldots$ & $\ldots$ & $\ldots$ \\
\hline Memorandum items: & & & usands $o$ & ric tons) & & \\
\hline \multicolumn{7}{|l|}{ Supply of rice } \\
\hline Domestic production 1/ & 239.6 & 257.0 & 198.1 & 311.1 & 422.1 & $\ldots$ \\
\hline Imports & 87.9 & 68.6 & 100.6 & 130.4 & 138.7 & 156.8 \\
\hline
\end{tabular}

Sources: Domestic production data from the Ministry of Agriculture, Forestry, and the Environment (Planning, Evaluation, Monitoring, and Statistics Division (PEMSD)). From 1991/92, import data from the Bank of Sierra Leone.

1/ Paddy converted to rice equivalent based on 5 percent seed, 15 percent postharvest loss, and 65 percent milling recovery rate 
Table 2. Sierra Leone: Domestic Fish Catch, 1998-2003

(In thousands of metric tons)

\begin{tabular}{lrrrrrr}
\hline & 1998 & 1999 & 2000 & 2001 & 2002 & 2003 \\
\hline Industrial catch & & & & & & \\
Shrimp & 1,317 & 1,483 & 1,505 & 1,277 & 1,119 & $\ldots$ \\
Tuna & 4,980 & 3,662 & $\ldots$ & 6,166 & $\ldots$ & $\ldots$ \\
Other & 7,521 & 10,673 & 12,689 & 15,155 & 12,602 & $\ldots$ \\
Total & 12,617 & 15,818 & 14,194 & 22,598 & 13,721 & $\ldots$ \\
& & & & & & \\
Artisanal catch & 46,648 & 46,420 & 45,910 & 39,950 & 52,846 & $\ldots$ \\
Total production & & & & & & \\
$\quad(1990=100)$ & 59,265 & 62,238 & 60,104 & 62,548 & 66,567 & $\ldots$ \\
\hline
\end{tabular}

Source: Ministry of Fisheries and Marine Resources, Sierra Leone. 
Table 3. Sierra Leone: Mineral Production, 1998-2003

\begin{tabular}{|c|c|c|c|c|c|c|}
\hline & 1998 & 1999 & 2000 & 2001 & 2002 & 2003 \\
\hline & \multicolumn{6}{|c|}{ (In units indicated) } \\
\hline \multicolumn{7}{|l|}{ Diamonds } \\
\hline \multicolumn{7}{|l|}{ Alluvial Diamond Mining Scheme 1/ } \\
\hline Quantity (thousands of carats) & 16 & 9 & 77 & 224 & 352 & 507 \\
\hline Export value (millions of leones) 2/ & 2,861 & 2,455 & 20,601 & 56,785 & 91,465 & 181,369 \\
\hline Bauxite (thousands of metric tons) 3/ & 0 & 0 & 0 & 0 & 0 & 0 \\
\hline Rutile (thousands of metric tons) $3 /$ & 0 & 5 & 0 & 0 & 0 & 0 \\
\hline Gold (ounces) 4/ & 22 & 0 & 0 & 0 & 0 & 0 \\
\hline \multirow[t]{2}{*}{ Ilmenite (thousands of metric tons) 3/ } & 0 & 3 & 0 & 0 & 0 & 0 \\
\hline & \multicolumn{6}{|c|}{$($ Index $1989 / 90=100)$} \\
\hline \multicolumn{7}{|l|}{ Memorandum items: } \\
\hline Alluvial Diamond Mining Scheme (quantity) & 14 & 8 & 25 & 193 & 303 & 437 \\
\hline Bauxite & 0 & 0 & 0 & 0 & 0 & 0 \\
\hline Rutile & 0 & 4 & 0 & 0 & 0 & 0 \\
\hline Gold & 0 & 0 & 0 & 0 & 0 & 0 \\
\hline Ilmenite & 0 & 4 & 0 & 0 & 0 & 0 \\
\hline
\end{tabular}

Sources: BSL Bulletin, Bank of Sierra Leone; and data provided by the Sierra Leonean authorities.

1/ Figures for exports under Alluvial Diamond Mining Scheme represent both gems and diamonds from 1990/91.

2/ Figures represent official sales of the Government Gold and Diamond Office (GGDO).

3/ The production of bauxite and rutile, as well as ilmenite (a by-product of rutile), ceased in January 1995 with the seizure of mine sites by forces hostile to the government.

4/ Amount of gold purchased by the Bank of Sierra Leone's gold buying unit, which suspended operations in November 1989, recommenced operations in October 1992, and ceased operations in June 1994. 
Table 4. Sierra Leone: Production of Manufacturing Establishments, 1998-2003

\begin{tabular}{|c|c|c|c|c|c|c|}
\hline & 1998 & 1999 & 2000 & 2001 & 2002 & 2003 \\
\hline & \multicolumn{6}{|c|}{ (In units indicated) } \\
\hline \multicolumn{7}{|l|}{ Food and beverages } \\
\hline Biscuits (thousands of kilograms) & 178 & 0 & 0 & 0 & 0 & 0 \\
\hline Confectionery (thousands of kilograms) & 1,661 & 815 & 382 & 500 & 1,032 & 1,505 \\
\hline Beer and stout (thousands of crates) & 489 & 0 & 188 & 401 & 915 & 771 \\
\hline Spirits (thousands of liters) & 0 & 0 & 0 & 0 & 0 & 0 \\
\hline Soft drinks (thousands of crates) & 848 & 787 & 1,429 & 1,701 & 1,872 & 1,113 \\
\hline \multicolumn{7}{|l|}{ Household products and construction } \\
\hline Matches (cartons) & 0 & 0 & 0 & 0 & 0 & 0 \\
\hline Washing soap (metric tons) & 323 & 302 & 493 & 149 & 460 & 492 \\
\hline Cement (thousands of bags) & 814 & 884 & 1,593 & 3,108 & 2,883 & 3,390 \\
\hline Nails (cases) & 0 & 0 & 0 & 0 & 0 & 0 \\
\hline Paint (thousands of liters) & 215 & 113 & 394 & 318 & 744 & 725 \\
\hline \multicolumn{7}{|l|}{ Miscellaneous } \\
\hline Cigarettes (millions of sticks) & $\ldots$ & $\ldots$ & ... & ... & $\ldots$ & ... \\
\hline Acetylene (thousands of cubic feet) & 68 & 14 & 100 & 91 & 99 & 114 \\
\hline Carbon dioxide (thousands of cubic feet) & 59 & 17 & 49 & 0 & 26 & 2 \\
\hline Oxygen (thousands of cubic feet) & 607 & 189 & 721 & 547 & 1,131 & 1,609 \\
\hline \multirow[t]{2}{*}{ Salt (metric tons) } & 2,325 & 1,229 & 3,970 & 1,833 & 1,821 & 1,005 \\
\hline & \multicolumn{6}{|c|}{ (Annual percentage change) } \\
\hline Beer and stout & 161.5 & -100.0 & ... & 113.0 & 128.1 & -15.7 \\
\hline Soft drinks & 7.2 & -7.1 & 81.5 & 19.0 & 10.1 & -40.5 \\
\hline Cigarettes & 0.0 & 0.0 & 0.0 & 0.0 & 0.0 & 0.0 \\
\hline
\end{tabular}

Sources: BSL Bulletin, Bank of Sierra Leone; and data provided by the Sierra Leonean authorities. 
Table 5. Sierra Leone: Petroleum Prices and Utility Tariffs, 2001-03

\begin{tabular}{|c|c|c|c|c|c|c|c|c|c|c|c|c|}
\hline \multirow[b]{2}{*}{ End of period } & \multicolumn{4}{|c|}{2001} & \multicolumn{4}{|c|}{2002} & \multicolumn{4}{|c|}{2003} \\
\hline & Mar. & Jun. & Sep. & Dec. & Mar. & Jun. & Sep. & Dec. & Mar. & Jun. & Sep. & $\overline{\text { Dec. }}$ \\
\hline & \multicolumn{12}{|c|}{ (Per imperial gallon) } \\
\hline \multicolumn{13}{|l|}{ Petroleum products } \\
\hline Petrol & 4,950 & 5,150 & 5,150 & 5,150 & 4,600 & 4,600 & 4,900 & 4,900 & 6,050 & 6,050 & 5,900 & 6,600 \\
\hline Diesel & 5,050 & 5,050 & 5,050 & 5,050 & 4,750 & 4,750 & 4,800 & 4,800 & 6,000 & 6,000 & 5,850 & 6,800 \\
\hline Kerosene & 3,500 & 3,500 & 3,500 & 3,500 & 3,350 & 3,350 & 3,500 & 3,500 & 4,750 & 4,750 & 4,600 & 5,200 \\
\hline Fuel oil & 2,120 & 2,120 & 2,120 & 2,120 & 2,250 & 2,250 & 2,400 & 2,400 & 3,305 & 3,305 & 3,070 & 3,480 \\
\hline & \multicolumn{12}{|c|}{ (Per unit) } \\
\hline \multicolumn{13}{|l|}{ Telecommunications } \\
\hline \multicolumn{13}{|l|}{ Telephone tariff (Le/Min.) } \\
\hline Local calls & 60 & 60 & 60 & 60 & 68 & 68 & 68 & 68 & 100 & 100 & 100 & 100 \\
\hline International calla & 2,400 & 2,400 & 2,400 & 2,400 & 2,200 & 2,200 & 2,200 & 2,200 & 2,000 & 2,000 & 2,000 & 1,500 \\
\hline \multicolumn{13}{|l|}{ Telephone rentals (Le/Month) } \\
\hline Domestic & 2,000 & 2,000 & 2,000 & 2,000 & 4,000 & 4,000 & 4,000 & 4,000 & 4,000 & 4,000 & 4,000 & 4,000 \\
\hline \multirow[t]{2}{*}{ Commercial } & 4,000 & 4,000 & 4,000 & 4,000 & 8,000 & 8,000 & 8,000 & 8,000 & 8,000 & 8,000 & 8,000 & 8,000 \\
\hline & \multicolumn{12}{|c|}{ (Leones per 1,000 gallons) } \\
\hline \multicolumn{13}{|l|}{ Water } \\
\hline Metered commercial & 4,000 & 4,000 & 4,000 & 4,000 & 4,000 & 4,000 & 4,000 & 4,000 & 5,000 & 5,000 & 5,000 & 5,000 \\
\hline & \multicolumn{12}{|c|}{ (Per unit) } \\
\hline \multicolumn{13}{|l|}{ Electricity } \\
\hline \multicolumn{13}{|l|}{ Domestic tariff } \\
\hline $0-30$ & 205 & 205 & 205 & 205 & 205 & 205 & 205 & 205 & 205 & 205 & 287 & 287 \\
\hline $31-150$ & 293 & 293 & 293 & 293 & 293 & 293 & 293 & 293 & 293 & 293 & 410 & 410 \\
\hline $151-200$ & 389 & 389 & 389 & 389 & 389 & 389 & 389 & 389 & 389 & 389 & 545 & 545 \\
\hline Over 151 & 389 & 389 & 389 & 389 & 389 & 389 & 389 & 389 & 389 & 389 & 0 & 0 \\
\hline Minimum charge (Leone) & 6,143 & 6,143 & 6,143 & 6,143 & 6,143 & 6,143 & 6,143 & 6,143 & 6,143 & 6,143 & 8,600 & 8,600 \\
\hline Fixed Charge (Leone) & 1,300 & 1,300 & 1,300 & 1,300 & 1,300 & 1,300 & 1,300 & 1,300 & 1,300 & 1,300 & 1,820 & 1,820 \\
\hline & \multicolumn{12}{|c|}{ (Below 15 kilowatts) } \\
\hline \multicolumn{13}{|l|}{ Nondomestic tariff } \\
\hline $0-30$ & 358 & 358 & 358 & 358 & 358 & 358 & 358 & 358 & 358 & 358 & 501 & 501 \\
\hline $31-150$ & 429 & 429 & 429 & 429 & 429 & 429 & 429 & 429 & 429 & 429 & 601 & 601 \\
\hline $151-200$ & 465 & 465 & 465 & 465 & 465 & 465 & 465 & 465 & 465 & 465 & 651 & 651 \\
\hline Over 151 & 465 & 465 & 465 & 465 & 465 & 465 & 465 & 465 & 465 & 465 & 0 & 0 \\
\hline Minimum charge (Leones) & 10,725 & 10,725 & 10,725 & 10,725 & 10,725 & 10,725 & 10,725 & 10,725 & 10,725 & 10,725 & 15,015 & 15,015 \\
\hline \multirow[t]{2}{*}{ Fixed Charge (Leones) } & 1,950 & 1,950 & 1,950 & 1,950 & 1,950 & 1,950 & 1,950 & 1,950 & 1,950 & 1,950 & 2,730 & 2,730 \\
\hline & & & & & & Above 15 & ilowatts) & & & & & \\
\hline All units & 519 & 521 & 521 & 521 & 521 & 521 & 521 & 521 & 521 & 521 & 729 & 729 \\
\hline Minimum charge & 65,000 & 65,000 & 65,000 & 65,000 & 65,000 & 65,000 & 65,000 & 65,000 & 65,000 & 65,000 & 91,000 & 91,000 \\
\hline Fixed charge & 26,000 & 26,000 & 26,000 & 26,000 & 26,000 & 26,000 & 26,000 & 26,000 & 26,000 & 26,000 & 37,240 & 37,240 \\
\hline $\begin{array}{l}\text { State-run educational institution } \\
\text { and hospitals }\end{array}$ & & & & & & & & & & & & \\
\hline All units & 519 & 521 & 521 & 521 & 521 & 521 & 521 & 521 & 521 & 521 & 729 & 729 \\
\hline Minimum charge & 65,000 & 65,000 & 65,000 & 65,000 & 65,000 & 65,000 & 65,000 & 65,000 & 65,000 & 65,000 & 91,000 & 91,000 \\
\hline Fixed charge & 26,000 & 26,000 & 26,000 & 26,000 & 26,000 & 26,000 & 26,000 & 26,000 & 26,000 & 26,000 & 37,240 & 37,240 \\
\hline Churches and mosques & & & & & & & & & & & & \\
\hline All units & 429 & 429 & 429 & 429 & 429 & 429 & 429 & 429 & 429 & 429 & 601 & 601 \\
\hline Minimum charge & 17,875 & 17,875 & 17,875 & 17,875 & 17,875 & 17,875 & 17,875 & 17,875 & 17,875 & 17,875 & 25,025 & 25,025 \\
\hline Fixed charge & 2,600 & 2,600 & 2,600 & 2,600 & 2,600 & 2,600 & 2,600 & 2,600 & 2,600 & 2,600 & 3,640 & 3,640 \\
\hline
\end{tabular}

Source: Data provided by the Sierra Leonean authorities. 
Table 6. Sierra Leone: Revised Consumer Price Index for Freetown 1998-March 2004 1/

$(1992=100)$

\begin{tabular}{|c|c|c|c|c|c|c|c|c|c|c|}
\hline Weights & $\begin{array}{l}\text { All items M } \\
\text { (CPI) }\end{array}$ & $\begin{array}{l}\text { onthly change } \mathrm{A} \\
\text { (In percent) }\end{array}$ & $\begin{array}{l}\text { Annual change } \\
\text { (In percent, } \\
\text { year-on-year) }\end{array}$ & $\begin{array}{r}\text { Food } \\
(54.13)\end{array}$ & $\begin{array}{r}\text { Beverages } \\
\text { and tobacco } \\
(3.63)\end{array}$ & $\begin{array}{r}\text { Nonfood 1/ } \\
(42.24)\end{array}$ & $\begin{array}{r}\text { Clothing } \\
(7.35)\end{array}$ & $\begin{array}{r}\text { Housing } \\
(14.75)\end{array}$ & $\begin{array}{r}\text { Transport and } \\
\text { communications } \\
(5.93)\end{array}$ & $\begin{array}{r}\text { Miscellaneous } \\
(14.21)\end{array}$ \\
\hline \multicolumn{11}{|l|}{2002} \\
\hline January & 514.5 & -2.2 & 6.3 & 295.2 & 12.5 & 206.8 & 24.1 & 89.6 & 29.9 & 12.9 \\
\hline February & 507.5 & -1.4 & 0.0 & 290.5 & 12.6 & 204.4 & 24.1 & 88.7 & 29.9 & 12.5 \\
\hline March & 497.8 & -1.9 & -3.8 & 279.1 & 12.7 & 206.0 & 24.3 & 88.6 & 29.9 & 12.4 \\
\hline April & 495.0 & -0.6 & -4.2 & 279.4 & 12.7 & 202.8 & 24.3 & 88.9 & 27.9 & 12.7 \\
\hline May & 498.9 & 0.8 & -3.7 & 282.4 & 12.7 & 203.8 & 24.5 & 88.7 & 27.9 & 13.3 \\
\hline June & 508.4 & 1.9 & -2.9 & 288.6 & 12.8 & 207.1 & 25.0 & 89.1 & 27.9 & 13.3 \\
\hline July & 518.8 & 2.0 & -1.8 & 294.6 & 12.8 & 211.4 & 25.4 & 91.8 & 27.9 & 13.4 \\
\hline August & 504.4 & -2.8 & -8.1 & 280.7 & 13.0 & 210.7 & 25.5 & 91.2 & 27.9 & 13.3 \\
\hline September & 495.4 & -1.8 & -7.7 & 272.1 & 13.0 & 210.2 & 25.5 & 91.4 & 27.9 & 13.2 \\
\hline October & 498.9 & 0.7 & -5.4 & 276.2 & 13.2 & 209.6 & 25.5 & 90.8 & 27.9 & 13.2 \\
\hline November & 498.0 & -0.2 & -3.8 & 272.9 & 13.1 & 212.1 & 26.5 & 90.5 & 27.9 & 13.2 \\
\hline December & 509.6 & 2.3 & -3.1 & 281.9 & 12.6 & 215.1 & 26.1 & 93.5 & 27.9 & 13.2 \\
\hline \multicolumn{11}{|l|}{2003} \\
\hline January & 513.8 & 0.8 & -0.1 & 285.3 & 12.9 & 215.7 & 26.6 & 96.8 & 27.9 & 13.2 \\
\hline February & 521.4 & 1.5 & 2.7 & 287.6 & 13.2 & 220.6 & 23.8 & 100.1 & 31.8 & 11.6 \\
\hline March & 529.7 & 1.6 & 6.4 & 291.3 & 13.3 & 225.1 & 23.9 & 99.4 & 27.8 & 11.0 \\
\hline April & 527.1 & -0.5 & 6.5 & 288.9 & 13.2 & 225.0 & 24.8 & 97.5 & 28.2 & 11.1 \\
\hline May & 529.5 & 0.5 & 6.1 & 290.9 & 13.5 & 225.2 & 24.9 & 97.3 & 28.2 & 11.2 \\
\hline June & 541.7 & 2.3 & 6.5 & 303.3 & 13.8 & 224.6 & 25.1 & 96.5 & 28.2 & 11.3 \\
\hline July & 545.7 & 0.7 & 5.2 & 305.5 & 14.0 & 226.3 & 25.2 & 96.8 & 28.0 & 10.6 \\
\hline August & 544.5 & -0.2 & 8.0 & 308.1 & 13.6 & 222.8 & 25.7 & 94.5 & 28.1 & 10.7 \\
\hline September & 551.1 & 1.2 & 11.3 & 313.2 & 13.7 & 224.2 & 27.4 & 93.0 & 28.5 & 10.7 \\
\hline October & 559.4 & 1.5 & 12.1 & 319.1 & 15.2 & 225.1 & 28.0 & 93.2 & 28.5 & 10.7 \\
\hline November & 572.4 & 2.3 & 14.9 & 330.0 & 15.1 & 227.2 & 27.9 & 93.3 & 28.7 & 12.1 \\
\hline December & 567.2 & -0.9 & 11.3 & 324.5 & 14.8 & 227.8 & 27.8 & 93.6 & 28.5 & 12.1 \\
\hline \multicolumn{11}{|l|}{2004} \\
\hline January & 592.5 & 4.5 & 15.3 & 351.3 & 13.9 & 227.3 & 27.2 & 94.7 & 28.6 & 12.7 \\
\hline February & 600.2 & 1.3 & 15.1 & 354.0 & 14.3 & 231.9 & 28.8 & 97.2 & 28.6 & 12.6 \\
\hline March & 588.9 & -1.9 & 11.2 & 341.3 & 14.4 & 233.3 & 28.9 & 98.1 & 28.7 & 12.6 \\
\hline \multicolumn{11}{|c|}{ Memorandum items: } \\
\hline \multicolumn{11}{|c|}{ Annual inflation rate } \\
\hline \multicolumn{11}{|l|}{ Average } \\
\hline 1998 & 35.5 & & & 30.8 & 23.4 & 40.1 & 35.4 & 49.8 & 13.8 & 31.3 \\
\hline 1999 & 34.1 & & & 42.0 & 54.3 & 22.2 & 17.6 & 29.8 & 7.9 & 11.9 \\
\hline 2000 & -0.9 & & & -8.0 & 6.1 & 5.9 & 6.5 & 4.6 & 50.4 & 2.5 \\
\hline 2001 & 2.2 & & & 6.8 & -16.3 & 1.2 & -11.5 & 2.0 & -13.5 & -4.0 \\
\hline 2002 & -3.3 & & & -2.3 & -19.5 & -3.4 & 2.0 & -2.9 & -6.0 & 9.2 \\
\hline 2003 & 7.6 & & & 7.5 & 8.6 & 7.6 & 3.2 & 6.4 & 0.4 & -13.0 \\
\hline \multicolumn{11}{|c|}{ End-December } \\
\hline 1998 & -5.7 & & & -7.4 & -18.2 & -2.5 & 18.3 & -14.2 & -38.5 & 0.0 \\
\hline 1999 & 36.7 & & & 40.6 & 77.8 & 29.6 & 19.7 & 38.6 & 81.1 & 24.1 \\
\hline 2000 & -2.7 & & & -3.4 & -10.4 & -1.3 & -11.1 & 0.8 & 4.7 & -13.4 \\
\hline 2001 & 3.4 & & & 11.3 & -24.4 & -4.3 & -4.8 & 0.0 & -16.9 & 14.7 \\
\hline 2002 & -3.1 & & & -7.4 & -3.1 & 3.2 & 10.6 & 1.7 & -6.7 & -0.8 \\
\hline 2003 & 11.3 & & & 15.1 & 17.5 & 5.9 & 6.5 & 0.1 & 2.2 & -8.3 \\
\hline
\end{tabular}

Sources: Data provided by Statistics Sierra Leone.

1/ Nonfood items consist of clothing, housing, transportation and communications, and miscellaneous. 
Table 7. Sierra Leone: Government Budgetary Operations, 1998-2003

\begin{tabular}{|c|c|c|c|c|c|c|}
\hline & 1998 & 1999 & 2000 & 2001 & 2002 & $\begin{array}{r}2003 \\
\text { Prel. }\end{array}$ \\
\hline & \multicolumn{6}{|c|}{ (In millions of leones) } \\
\hline Domestic Revenue & 77,199 & 85,819 & 152,175 & 207,669 & 238,691 & 287,657 \\
\hline Tax & 67,704 & 76,016 & 135,166 & 192,576 & 223,470 & 267,960 \\
\hline Nontax & 9,495 & 9,803 & 17,009 & 15,093 & 15,221 & 19,697 \\
\hline Grants & 25,087 & 65,391 & 106,107 & 95,023 & 161,336 & 179,343 \\
\hline Expenditure & 211,523 & 265,605 & 382,344 & 442,760 & 562,252 & 597,999 \\
\hline Recurrent expenditure & 159,384 & 235,939 & 301,831 & 371,132 & 474,811 & 485,368 \\
\hline Development expenditure and net lending & 52,139 & 29,666 & 80,512 & 71,628 & 87,441 & 112,631 \\
\hline \multicolumn{7}{|l|}{ Overall deficit (commitment basis) } \\
\hline Excluding grants & $-134,324$ & $-179,786$ & $-230,169$ & $-235,091$ & $-323,561$ & $-310,342$ \\
\hline Including grants & $-109,238$ & $-114,395$ & $-124,062$ & $-140,068$ & $-162,225$ & $-130,999$ \\
\hline Change in arrears & 36,293 & 33,799 & 43,310 & $-533,199$ & $-3,586$ & $-13,539$ \\
\hline Overall deficit (cash basis) & $-72,945$ & $-80,596$ & $-80,752$ & $-673,267$ & $-165,811$ & $-144,538$ \\
\hline Total financing & 72,945 & 80,596 & 80,752 & 673,267 & 165,811 & 144,538 \\
\hline Foreign financing & 14,323 & $-14,674$ & 81,610 & 624,766 & 143,734 & 56,133 \\
\hline Disbursements & 50,269 & 20,184 & 123,584 & 95,370 & 141,605 & 93,627 \\
\hline Amortization due & $-35,946$ & $-34,857$ & $-41,974$ & $-38,515$ & $-48,284$ & $-37,494$ \\
\hline Amount paid & $\ldots$ & $\ldots$ & $-11,202$ & $-425,769$ & $-34,250$ & $-37,494$ \\
\hline Arrears & $\ldots$ & $\ldots$ & 30,772 & $-387,254$ & 14,034 & 0 \\
\hline Debt relief obtained & $\ldots$ & $\ldots$ & $\ldots$ & 567,911 & 50,413 & 0 \\
\hline Domestic financing & 41,561 & 88,807 & 968 & 51,791 & 18,600 & 100,652 \\
\hline Bank & 21,129 & 82,810 & $-26,321$ & 42,844 & $-5,603$ & 56,622 \\
\hline Nonbank & 20,432 & 5,997 & 27,289 & 8,947 & 24,203 & 44,030 \\
\hline Privatization & 150 & 176 & 22 & 2,060 & 472 & 270 \\
\hline \multirow[t]{2}{*}{ Float/unaccounted } & 16,910 & 6,287 & $-1,848$ & $-5,350$ & 3,005 & $-12,517$ \\
\hline & \multicolumn{6}{|c|}{ (In percent of GDP) } \\
\hline Revenue & 7.3 & 7.1 & 11.4 & 14.0 & 14.5 & 15.4 \\
\hline Expenditure & 20.1 & 22.0 & 28.7 & 29.8 & 34.2 & 32.1 \\
\hline Recurrent expenditure & 15.2 & 19.5 & 22.7 & 24.9 & 28.9 & 26.1 \\
\hline Development expenditure & 5.0 & 2.5 & 6.1 & 4.8 & 5.3 & 6.0 \\
\hline \multicolumn{7}{|l|}{ Overall deficit (commitment basis) } \\
\hline excluding grants & -12.8 & -14.9 & -17.3 & -15.8 & -19.7 & -16.7 \\
\hline including grants & -10.4 & -9.5 & -9.3 & -9.4 & -9.9 & -7.0 \\
\hline Change in arrears & 3.5 & 2.8 & 3.3 & -35.8 & -0.2 & -0.7 \\
\hline Overall deficit (cash basis) & -6.9 & -6.7 & -6.1 & -45.3 & -10.1 & -7.8 \\
\hline Foreign financing & 1.4 & -1.2 & 6.1 & 42.0 & 8.7 & 3.0 \\
\hline Domestic financing & 4.0 & 7.4 & 0.1 & 3.5 & 1.1 & 5.4 \\
\hline Bank & 2.0 & 6.9 & -2.0 & 2.9 & -0.3 & 3.0 \\
\hline Nonbank & 1.9 & 0.5 & 2.1 & 0.6 & 1.5 & 2.4 \\
\hline Privatization & 0.0 & 0.0 & 0.0 & 0.1 & 0.0 & 0.0 \\
\hline Float/unaccounted & 1.6 & 0.5 & -0.1 & -0.4 & 0.2 & -0.7 \\
\hline \multicolumn{7}{|l|}{ Memorandum items: } \\
\hline Opening money stock (in millions of Leones) & 126,633 & 140,898 & 134,078 & 139,957 & 189,437 & 247,478 \\
\hline Bank financing/Broad money & 16.7 & 58.8 & -19.6 & 30.6 & -3.0 & 22.9 \\
\hline Primary budget deficit (commitment basis) & $-40,305$ & $-66,131$ & $-73,060$ & $-80,716$ & $-74,686$ & $-136,116$ \\
\hline (In percent of GDP) & -3.8 & -5.5 & -5.5 & -5.4 & -4.5 & -7.3 \\
\hline GDP at current market prices & $1,051,335$ & $1,207,721$ & $1,330,319$ & $1,487,724$ & $1,643,332$ & $1,863,000$ \\
\hline
\end{tabular}

Source: Sierra Leonean authorities. GDP data deviate from IMF estimates. 
Table 8. Sierra Leone: Government Revenue, 1998-2003

\begin{tabular}{|c|c|c|c|c|c|c|}
\hline & 1998 & 1999 & 2000 & 2001 & 2002 & $\begin{array}{l}2003 \\
\text { Prel. }\end{array}$ \\
\hline & \multicolumn{6}{|c|}{ (In millions of leones) } \\
\hline Taxes on income and profit & 12,235 & 21,979 & 39,243 & 53,697 & 61,642 & 73,046 \\
\hline Corporate profits tax & 6,418 & 8,430 & 15,929 & 19,994 & 29,117 & 38,578 \\
\hline Individual income tax & 5,817 & 13,549 & 23,314 & 33,703 & 32,525 & 34,468 \\
\hline Taxes on goods and services & 19,534 & 18,484 & 27,908 & 43,751 & 51,154 & 63,742 \\
\hline Excise duties & 11,689 & 12,482 & 18,974 & 27,036 & 32,128 & 41,195 \\
\hline Fuel and oil & 10,158 & 10,603 & 18,008 & 21,024 & 28,337 & 36,693 \\
\hline Tobacco & $\ldots$ & $\ldots$ & $\ldots$ & $\ldots$ & $\ldots$ & $\ldots$ \\
\hline \multicolumn{7}{|l|}{ Beer and stout } \\
\hline Other $1 /$ & 1,531 & 1,880 & 966 & 6,012 & 3,791 & 4,502 \\
\hline Domestic sales tax & 1,871 & 415 & 533 & 6,670 & 7,758 & 7,018 \\
\hline Mining licenses & 1,551 & 491 & 729 & 1,196 & 2,034 & 3,040 \\
\hline Royalties & 1,562 & 2,279 & 3,031 & 2,664 & 2,309 & 2,643 \\
\hline Bauxite & 0 & 0 & 3 & 0 & 0 & 0 \\
\hline Rutile & 0 & 0 & 786 & 0 & 0 & 0 \\
\hline Fisheries & 1,562 & 2,278 & 2,242 & 2,664 & 2,309 & 2,643 \\
\hline Road user fees & 2,860 & 2,817 & 4,641 & 6,185 & 6,925 & 9,847 \\
\hline Other taxes on goods and services & 0 & 0 & 0 & 0 & 0 & 0 \\
\hline Taxes on international travel & ... & $\ldots$ & $\ldots$ & $\cdots$ & $\cdots$ & ... \\
\hline Taxes on international trade & 40,823 & 40,974 & 75,917 & 104,475 & 120,703 & 144,166 \\
\hline Import duties & 40,823 & 40,974 & 75,917 & 104,475 & 120,703 & 144,166 \\
\hline Import duty and fees & 40,823 & 40,974 & 75,917 & 104,475 & 120,703 & 144,166 \\
\hline Import sales tax & 0 & 0 & 0 & 0 & 0 & 0 \\
\hline Other charges & 0 & 0 & 0 & 0 & 0 & 0 \\
\hline Export duties & 0 & 0 & 0 & 0 & 0 & 0 \\
\hline Other taxes & 3,100 & 3,036 & 1,247 & 698 & 1,239 & 2,535 \\
\hline Employers' payroll tax & $\ldots$ & $\ldots$ & $\ldots$ & $\ldots$ & $\ldots$ & $\ldots$ \\
\hline Freight levy & 2,014 & 734 & 748 & 0 & 0 & 0 \\
\hline Other $2 /$ & 1,086 & 2,301 & 499 & 698 & 1,239 & 2,535 \\
\hline Total tax revenue & 75,692 & 84,472 & 144,315 & 202,621 & 234,738 & 283,489 \\
\hline Nontax revenue & 1,507 & 1,347 & 7,859 & 5,048 & 3,952 & 4,168 \\
\hline Property income & $\ldots$ & $\ldots$ & $\ldots$ & $\ldots$ & $\ldots$ & $\ldots$ \\
\hline Public enterprises & $\cdots$ & $\ldots$ & $\ldots$ & $\cdots$ & $\cdots$ & $\cdots$ \\
\hline Other & $\ldots$ & $\ldots$ & $\ldots$ & $\ldots$ & $\ldots$ & $\ldots$ \\
\hline Administration fees and other charges & $\ldots$ & $\ldots$ & $\ldots$ & $\ldots$ & $\ldots$ & $\ldots$ \\
\hline Other & 1,507 & 1,347 & 7,859 & 5,048 & 3,952 & 4,168 \\
\hline \multirow[t]{2}{*}{ Total revenue } & 77,199 & 85,819 & 152,174 & 207,669 & 238,690 & 287,657 \\
\hline & \multicolumn{6}{|c|}{ (In percent of GDP) } \\
\hline Taxes on income and profit & 1.2 & 1.8 & 2.9 & 3.6 & 3.7 & 3.9 \\
\hline Taxes on goods and services & 1.9 & 1.5 & 2.1 & 2.9 & 3.0 & 3.4 \\
\hline Taxes on international trade & 3.9 & 3.4 & 5.7 & 7.0 & 7.2 & 7.7 \\
\hline Other taxes & 0.3 & 0.3 & 0.1 & 0.0 & 0.1 & 0.1 \\
\hline Tax revenue & 7.2 & 7.0 & 10.8 & 13.6 & 14.0 & 15.2 \\
\hline Nontax revenue & 0.1 & 0.1 & 0.6 & 0.3 & 0.2 & 0.2 \\
\hline \multirow[t]{2}{*}{ Total revenue } & 7.3 & 7.1 & 11.4 & 14.0 & 14.2 & 15.4 \\
\hline & \multicolumn{6}{|c|}{ (In perent of total revenue) } \\
\hline Taxes on income and profit & 15.8 & 25.6 & 25.8 & 25.9 & 25.8 & 25.4 \\
\hline Taxes on goods and services & 25.3 & 21.5 & 18.3 & 21.1 & 12.2 & 13.4 \\
\hline Taxes on international trade & 52.9 & 47.7 & 49.9 & 50.3 & 13.6 & 12.0 \\
\hline Other taxes & 4.0 & 3.5 & 0.8 & 0.3 & 0.0 & 0.0 \\
\hline Tax revenue & 98.0 & 98.4 & 94.8 & 97.6 & 21.4 & 22.2 \\
\hline Nontax revenue & 2.0 & 1.6 & 5.2 & 2.4 & 13.5 & 14.3 \\
\hline
\end{tabular}

Sources: Sierra Leonean authorities.

1/ For 1996, includes excise duties collected on tobacco and beer and stout.

2/ For 1996, includes employers' payroll tax and taxes on international travel. 
Table 9. Sierra Leone: Economic Classification of Recurrent Expenditure, 1998-2003

\begin{tabular}{|c|c|c|c|c|c|c|}
\hline & 1998 & 1999 & 2000 & 2001 & 2002 & 2003 \\
\hline & \multicolumn{6}{|c|}{ (In millions of leones; unless otherwise stated) } \\
\hline Wages and salaries & 50,754 & 73,032 & 89,495 & 110,981 & 126,492 & 152,003 \\
\hline \multicolumn{7}{|l|}{ Of which } \\
\hline Rice supplement & 516 & 0 & 0 & 0 & 0 & 0 \\
\hline Purchases of goods and services & 46,551 & 83,675 & 116,904 & 164,327 & 212,728 & 222,088 \\
\hline \multicolumn{7}{|l|}{ Of which } \\
\hline Emergency defense & 10,221 & 30,672 & 28,636 & 37,868 & 33,371 & 40,774 \\
\hline Subsidies and transfers & 9,035 & 8,994 & 11,518 & 14,801 & 30,809 & 27,506 \\
\hline Education & 7,428 & 8,871 & 11,475 & 13,141 & 14,041 & 19,000 \\
\hline Liberian relief operations $1 /$ & 1,578 & 0 & 0 & 0 & 0 & 0 \\
\hline Local government & 30 & 123 & 43 & 1,660 & 1,469 & 417 \\
\hline Pensions & 0 & 0 & 0 & 0 & 15,300 & 8,088 \\
\hline Interest & 50,644 & 70,238 & 83,915 & 72,796 & 104,798 & 83,771 \\
\hline Domestic & 22,822 & 43,933 & 50,459 & 44,263 & 51,020 & 64,316 \\
\hline Foreign & 27,822 & 26,305 & 33,456 & 28,533 & 53,778 & 19,455 \\
\hline Total recurrent expenditure & 156,984 & 235,939 & 301,832 & 362,904 & 474,827 & 485,368 \\
\hline & \multicolumn{6}{|c|}{ (In percent of GDP) } \\
\hline Wages and salaries & 4.8 & 6.0 & 6.7 & 7.5 & 7.5 & 8.2 \\
\hline \multicolumn{7}{|l|}{ Of which } \\
\hline Rice supplement & 0.0 & 0.0 & 0.0 & 0.0 & 0.0 & 0.0 \\
\hline Purchases of goods and services & 4.4 & 6.9 & 8.8 & 11.0 & 12.7 & 11.9 \\
\hline \multicolumn{7}{|l|}{ Of which } \\
\hline Emergency defense & 1.0 & 2.5 & 2.2 & 2.5 & 2.0 & 2.2 \\
\hline Subsidies and transfers & 0.9 & 0.7 & 0.9 & 1.0 & 1.8 & 1.5 \\
\hline Interest & 4.8 & 5.8 & 6.3 & 4.9 & 6.2 & 4.5 \\
\hline \multicolumn{7}{|l|}{ Of which } \\
\hline Domestic & 2.2 & 3.6 & 3.8 & 3.0 & 3.0 & 3.5 \\
\hline & \multicolumn{6}{|c|}{ (In percent of total recurrent expenditure) } \\
\hline Wages and salaries & 32.3 & 31.0 & 29.7 & 30.6 & 26.6 & 31.3 \\
\hline Purchases of goods and services & 29.7 & 35.5 & 38.7 & 45.3 & 44.8 & 45.8 \\
\hline Subsidies and transfers & 5.8 & 3.8 & 3.8 & 4.1 & 6.5 & 5.7 \\
\hline Interest & 32.3 & 29.8 & 27.8 & 20.1 & 22.1 & 17.3 \\
\hline \multicolumn{7}{|l|}{ Of which } \\
\hline Domestic & 14.5 & 18.6 & 16.7 & 12.2 & 10.7 & 13.3 \\
\hline GDP (millions of leones) & $1,051,335$ & $1,207,721$ & $1,330,319$ & $1,487,724$ & $1,678,000$ & $1,863,000$ \\
\hline
\end{tabular}

Sources: Data provided by the Sierra Leonean authorities.

1/ Sierra Leonean government's contribution to ECOMOG (Economic Community of West African States (ECOWAS) Monitoring Group) 
Table 10. Sierra Leone: Functional Classification of Recurrent Expenditure, 1998-2003

\begin{tabular}{|c|c|c|c|c|c|c|}
\hline & 1998 & 1999 & 2000 & 2001 & 2002 & $\begin{array}{c}2003 \\
\text { Prel. }\end{array}$ \\
\hline & \multicolumn{6}{|c|}{ (In millions of leones) } \\
\hline General public services & 19,067 & 32,585 & 49,791 & 72,891 & 99,129 & 105,338 \\
\hline Defense & 15,721 & 30,672 & 48,769 & 59,408 & 56,955 & 66,841 \\
\hline Education & 26,251 & 43,744 & 59,024 & 68,136 & 87,037 & 101,901 \\
\hline General administration & 2,016 & 2,655 & 3,450 & 5,305 & 6,689 & 7,640 \\
\hline Schools & 14,744 & 29,816 & 41,430 & 47,195 & 62,152 & 70,468 \\
\hline Primary & 9,157 & 19,743 & 28,833 & 31,590 & 44,385 & 49,468 \\
\hline Secondary & 5,587 & 10,073 & 12,597 & 15,605 & 17,767 & 21,000 \\
\hline Universities and colleges & 8,000 & 8,871 & 11,475 & 13,141 & 14,041 & 19,000 \\
\hline Technical and vocational & 1,491 & 2,402 & 2,670 & 2,495 & 4,156 & 4,793 \\
\hline Health & 8,154 & 6,787 & 14,280 & 23,510 & 33,595 & 40,200 \\
\hline Social security and welfare & 3,595 & 6,015 & 7,041 & 8,791 & 20,261 & 20,302 \\
\hline General administration & 438 & 195 & 0 & 0 & 0 & 3,007 \\
\hline Pensions & 3,157 & 5,820 & 7,041 & 8,791 & 20,261 & 17,296 \\
\hline Housing and community amenities & 573 & 460 & 978 & 1,522 & 1,740 & 1,446 \\
\hline Other community and social services & 2,519 & 2,905 & 4,893 & 4,709 & 7,922 & 5,995 \\
\hline Economic services & 10,575 & 13,537 & 16,567 & 28,401 & 32,761 & 39,109 \\
\hline Agriculture & 4,004 & 4,252 & 5,094 & 8,849 & 10,933 & 15,199 \\
\hline Mining and manufacturing & 544 & 573 & 823 & 1,105 & 1,159 & 1,243 \\
\hline Electricity and water & 872 & 1,103 & 1,630 & 2,904 & 4,142 & 3,989 \\
\hline Transportation & 724 & 848 & 671 & 4,042 & 3,384 & 2,344 \\
\hline Other & 4,431 & 6,761 & 8,350 & 11,501 & 13,144 & 16,335 \\
\hline Unallocated and other purposes & 72,929 & 99,144 & 103,506 & 95,538 & 140,931 & 104,958 \\
\hline Public debt interest and commissions & 50,184 & 70,238 & 83,915 & 72,796 & 104,798 & 83,771 \\
\hline Other purposes & 22,745 & 28,906 & 19,591 & 22,742 & 36,133 & 21,187 \\
\hline \multirow[t]{2}{*}{ Total recurrent expenditure } & 159,384 & 235,849 & 304,848 & 362,907 & 480,331 & 486,092 \\
\hline & \multicolumn{6}{|c|}{ (In percent of GDP) } \\
\hline General public services & 1.8 & 2.7 & 3.7 & 4.9 & 5.9 & 5.7 \\
\hline Defense & 1.5 & 2.5 & 3.7 & 4.0 & 3.4 & 3.6 \\
\hline Education & 2.5 & 3.6 & 4.4 & 4.6 & 5.2 & 5.5 \\
\hline Health & 0.8 & 0.6 & 1.1 & 1.6 & 2.0 & 2.2 \\
\hline Social security and welfare & 0.3 & 0.5 & 0.5 & 0.6 & 1.2 & 1.1 \\
\hline Housing and community amenities & 0.1 & 0.0 & 0.1 & 0.1 & 0.1 & 0.1 \\
\hline Other community and social services & 0.2 & 0.2 & 0.4 & 0.3 & 0.5 & 0.3 \\
\hline Economic services & 1.0 & 1.1 & 1.2 & 1.9 & 2.0 & 2.1 \\
\hline Public debt interest and commissions & 4.8 & 5.8 & 6.3 & 4.9 & 6.2 & 4.5 \\
\hline \multirow[t]{2}{*}{ Other purposes } & 2.2 & 2.4 & 1.5 & 1.5 & 2.2 & 1.1 \\
\hline & \multicolumn{6}{|c|}{ (In percent of total recurrent expenditure) } \\
\hline General public services & 12.0 & 13.8 & 16.3 & 20.1 & 20.6 & 21.7 \\
\hline Defense & 9.9 & 13.0 & 16.0 & 16.4 & 11.9 & 13.8 \\
\hline Education & 16.5 & 18.5 & 19.4 & 18.8 & 18.1 & 21.0 \\
\hline Health & 5.1 & 2.9 & 4.7 & 6.5 & 7.0 & 8.3 \\
\hline Social security and welfare & 2.3 & 2.5 & 2.3 & 2.4 & 4.2 & 4.2 \\
\hline Housing and community amenities & 0.4 & 0.2 & 0.3 & 0.4 & 0.4 & 0.3 \\
\hline Other community and social services & 1.6 & 1.2 & 1.6 & 1.3 & 1.6 & 1.2 \\
\hline Economic services & 6.6 & 5.7 & 5.4 & 7.8 & 6.8 & 8.0 \\
\hline Public debt interest and commissions & 31.5 & 29.8 & 27.5 & 20.1 & 21.8 & 17.2 \\
\hline Other purposes & 14.3 & 12.3 & 6.4 & 6.3 & 7.5 & 4.4 \\
\hline
\end{tabular}

Source: Sierra Leonean authorities. 
Table 11. Sierra Leone: Government Debt Outstanding by Type of Holder and Instrument, 1998-2003

\begin{tabular}{|c|c|c|c|c|c|c|}
\hline & 1998 & 1999 & 2000 & 2001 & 2002 & 2003 \\
\hline & \multicolumn{6}{|c|}{ (In millions of leones) } \\
\hline Domestic debt & 528,519 & 625,546 & 760,584 & 802,989 & 879,203 & 945,708 \\
\hline Government stock & 398,762 & 398,386 & 532,670 & 532,025 & 532,025 & 532,025 \\
\hline Bank of Sierra Leone & 398,762 & 398,386 & 532,670 & 532,025 & 532,025 & 532,025 \\
\hline Commercial banks & 0 & 0 & 0 & 0 & 0 & 0 \\
\hline Other $1 /$ & 0 & 0 & 0 & 0 & 0 & 0 \\
\hline Treasury bills $2 /$ & 64,033 & 95,289 & 91,071 & 120,039 & 187,646 & 231,533 \\
\hline Bank of Sierra Leone & 16,289 & 18,220 & 3,954 & 2,252 & 33,597 & 65,610 \\
\hline Commercial banks & 40,039 & 70,049 & 67,440 & 101,661 & 117,347 & 113,415 \\
\hline Other $1 /$ & 7,705 & 7,020 & 19,678 & 16,126 & 36,702 & 52,508 \\
\hline Treasury bearer bonds 3 / & 28,777 & 26,179 & 45,839 & 63,638 & 85,253 & 114,041 \\
\hline Bank of Sierra Leone & 10,675 & 495 & 2,045 & 4,416 & 12,101 & 17,219 \\
\hline Commercial banks & 800 & 1,700 & 5,179 & 8,109 & 18,411 & 14,545 \\
\hline Other $1 /$ & 17,302 & 23,984 & 38,615 & 51,114 & 54,741 & 82,277 \\
\hline \multicolumn{7}{|l|}{ Short-term loans and advances from the } \\
\hline Bank of Sierra Leone & 36,947 & 105,692 & 91,005 & 87,286 & 74,279 & 68,109 \\
\hline Ways and means advances & 36,620 & 105,150 & 90,529 & 86,680 & 74,279 & 68,109 \\
\hline Other advances & 327 & 542 & 476 & 606 & 0 & 0 \\
\hline Foreign debt & $1,843,915$ & $2,207,992$ & $2,538,835$ & $2,361,786$ & $3,223,142$ & $3,823,989$ \\
\hline International development institutions & $1,089,687$ & $1,297,711$ & $1,527,817$ & $1,433,821$ & $1,843,654$ & $2,218,542$ \\
\hline Foreign governments & 552,521 & 709,442 & 831,332 & 755,617 & 853,419 & $1,019,558$ \\
\hline Suppliers' credit & 0 & 0 & 0 & 0 & 0 & 0 \\
\hline Other loans & 201,707 & 200,839 & 179,686 & 172,348 & 526,069 & 585,888 \\
\hline Total debt & $2,372,433$ & $2,833,538$ & $3,299,420$ & $3,164,776$ & $4,102,345$ & $4,769,697$ \\
\hline \multicolumn{7}{|l|}{ Memorandum items: } \\
\hline \multicolumn{7}{|l|}{ Type of domestic debt instrument } \\
\hline Government stock & 75.4 & 63.7 & 70.0 & 66.3 & 60.5 & 56.3 \\
\hline Treasury bills & 12.1 & 15.2 & 12.0 & 14.9 & 21.3 & 24.5 \\
\hline Treasury bearer bonds & 5.4 & 4.2 & 6.0 & 7.9 & 9.7 & 12.1 \\
\hline Short-term loans and advances & 7.0 & 16.9 & 12.0 & 10.9 & 8.4 & 7.2 \\
\hline \multicolumn{7}{|l|}{ Type of debt holder } \\
\hline \multicolumn{7}{|l|}{ Domestic } \\
\hline Bank of Sierra Leone & 85.5 & 83.5 & 82.5 & 77.4 & 72.8 & 70.4 \\
\hline Commercial banks & 7.6 & 11.2 & 8.9 & 12.7 & 13.3 & 12.0 \\
\hline \multicolumn{7}{|l|}{ Foreign } \\
\hline International development institutio] & 59.1 & 58.8 & 60.2 & 60.7 & 57.2 & 58.0 \\
\hline Foreign governments & 30.0 & 32.1 & 32.7 & 32.0 & 26.5 & 26.7 \\
\hline Suppliers' credit & 0.0 & 0.0 & 0.0 & 0.0 & 0.0 & 0.0 \\
\hline Other loans & 10.9 & 9.1 & 7.1 & 7.3 & 16.3 & 15.3 \\
\hline \multicolumn{7}{|l|}{ Total debt/GDP } \\
\hline Domestic debt/GDP & 50.3 & 51.8 & 57.2 & 54.0 & 53.5 & 50.8 \\
\hline Foreign debt/GDP & 175.4 & 182.8 & 190.8 & 158.8 & 196.1 & 205.3 \\
\hline
\end{tabular}

Source: Data provided by the Sierra Leonean authorities.

1/ Includes nonbank public and public sector enterprises.

2/ Special treasury bills were issued to the nonbank public for the first time in 1980/81 and were retired in June 1983. They were reissued beginning in 1986 and discontinued again in late 1992, when special and regular markets for treasury $t$ 3/ One-year bearer bonds introduced in August 1993. 
Table 12. Sierra Leone: List of Public Enterprises

(As of March 31, 2004)

\begin{tabular}{|c|c|c|c|c|c|c|}
\hline Name & Sector & Legal status & $\begin{array}{l}\text { Government } \\
\text { participation } \\
\text { (In percent) }\end{array}$ & \multicolumn{2}{|c|}{$\begin{array}{ll}\text { Capital Turnover } \\
\text { (In millions of Leones) }\end{array}$} & $\begin{array}{c}\text { Personnel } \\
\text { (no. of persons) }\end{array}$ \\
\hline Sierra Leone Commercial Bank Ltd & Banking & Limited Company & 100 & 1,000 & 4,860 & 309 \\
\hline Rokel Commercial Bank Ltd. & Banking & Limited Company & 51 & 1,119 & 7,310 & 229 \\
\hline National Development Bank Ltd & Banking & Limited Company & 99 & 1,604 & 18 & 27 \\
\hline Guma Valley Water Company Ltd & Energy & Limited Company & 95 & 1,223 & 1,026 & 376 \\
\hline Sierra Leone Ports Authority & Transport & Authority & 100 & 3 & 4,374 & 1,561 \\
\hline Sierra Leone State Lottery Co. Ltd & Finance & Limited Company & 100 & 0 & 2,374 & 126 \\
\hline National Insurance Company Ltd & Insurance & Limited Company & 100 & 463 & 1,119 & 83 \\
\hline Sierra Leone National Shipping Co. Ltd & Shipping & Limited Company & 100 & 0.1 & 268 & 54 \\
\hline Mining and General Services Ltd. & Shipping & Limited Company & 51 & 861 & 673 & 27 \\
\hline Sierra Leone Road Transport Corporation & Transport & Corporation & 100 & 184 & 549 & 154 \\
\hline Sierra Leone Airports Authority & Transport & Authority & 100 & 1,004 & 3,567 & 292 \\
\hline Sierra Leone Roads Authority & Works & Authority & 100 & 1,679 & 5,937 & 404 \\
\hline Sierra Leone Telecommunications Co. Ltd & Communications & Limited Company & 100 & 25,813 & 8,000 & 1,079 \\
\hline Sierra National Airlines & Transport & Limited Company & 100 & 1 & 12,436 & 185 \\
\hline Sierra Leone Postal Services & Telecommunications & Limited Company & 100 & 20 & 280 & 271 \\
\hline National Power Authority & Energy & Authority & 100 & 2 & 10,123 & 583 \\
\hline Sierra Leone Housing Corporation & Housing & Corporation & 100 & 15,437 & 91 & 44 \\
\hline Forest Industries Corporation & Forestry & Corporation & 100 & 150 & 62 & 60 \\
\hline National Workshop & Trade & Company & 40 & n.a. & n.a. & n.a. \\
\hline Sierra Leone Daily Mail & Media & Company & 100 & n.a. & n.a. & n.a. \\
\hline Sierra Leone Government Printing Dept. & Media & Department & 100 & n.a. & n.a. & n.a. \\
\hline Sierra Leone Broadcasting Service Ltd & Media & Department & 100 & n.a. & n.a. & n.a. \\
\hline
\end{tabular}

Source: National Commission for Privatisation. 
Table 13. Sierra Leone: Summary Account for the Commercial Banks, March 2001-March 2004 (In millions of leones)

\begin{tabular}{|c|c|c|c|c|c|c|c|c|c|c|c|c|c|}
\hline & \multicolumn{4}{|c|}{2001} & \multicolumn{4}{|c|}{2002} & \multicolumn{4}{|c|}{2003} & \multirow{2}{*}{$\begin{array}{l}2004 \\
\text { Mar. }\end{array}$} \\
\hline & $\overline{\text { Mar. }}$ & Jun. & Sept. & Dec. & Mar. & Jun. & Sept. & Dec. & Mar. & Jun. & Sept. & Dec. & \\
\hline Net Foreign Assets & 46,846 & 46,621 & 44,586 & 47,295 & 64,268 & 52,402 & 57,872 & 58,383 & 62,738 & 76,613 & 75,106 & 78,839 & 88,910 \\
\hline Assets & 46,846 & 46,621 & 44,586 & 47,295 & 64,268 & 52,402 & 57,872 & 58,383 & 62,738 & 76,613 & 75,106 & 78,839 & 88,910 \\
\hline Liabilities & 0 & 0 & 0 & 0 & 0 & 0 & 0 & 0 & 0 & 0 & 0 & 0 & 0 \\
\hline Reserve & 12,354 & 12,206 & 10,546 & 17,047 & 15,539 & 11,070 & 14,933 & 21,696 & 12,818 & 13,119 & 15,946 & 20,099 & 19,945 \\
\hline Cash in hand & 4,762 & 4,522 & 4,435 & 9,785 & 6,550 & 6,857 & 7,915 & 10,579 & 7,703 & 9,672 & 10,296 & 11,140 & 10,260 \\
\hline Deposits at Central Bank & 7,591 & 7,685 & 6,111 & 7,262 & 8,989 & 4,213 & 7,018 & 11,117 & 5,115 & 3,447 & 5,650 & 8,959 & 9,685 \\
\hline Net Claims on Government 1/ & 82,494 & 82,979 & 98,929 & 89,854 & 86,595 & 106,354 & 104,839 & 114,994 & 128,363 & 124,380 & 130,920 & 113,068 & 127,462 \\
\hline Treasury Bills & 90,666 & 85,198 & 103,661 & 91,200 & 91,550 & 99,476 & 106,373 & 115,165 & 123,327 & 122,475 & 127,570 & 107,492 & 127,715 \\
\hline Treasury Bearer Bonds & 4,456 & 6,453 & 8,109 & 9,356 & 11,557 & 15,076 & 14,391 & 14,776 & 13,281 & 9,066 & 11,316 & 13,963 & 11,358 \\
\hline Loans and Advances & 327 & 289 & 606 & 192 & 257 & 1,177 & 198 & 94 & 285 & 305 & 301 & 373 & 268 \\
\hline Government Securities & 0 & 500 & 0 & 0 & 0 & 0 & 0 & 0 & 0 & 0 & 0 & 0 & 0 \\
\hline Government Deposits & $-12,956$ & $-9,461$ & $-13,447$ & $-10,894$ & $-16,769$ & $-9,375$ & $-16,123$ & $-15,041$ & $-8,530$ & $-7,466$ & $-8,267$ & $-8,760$ & $-11,879$ \\
\hline Claims on Public entities & 240 & 418 & 349 & 486 & 412 & 87 & 817 & 950 & 1,418 & 2,741 & 2,851 & 3,647 & 3,805 \\
\hline Claims on Private Sector 2/ & 26,754 & 26,284 & 29,707 & 32,974 & 40,725 & 37,103 & 42,891 & 50,559 & 61,495 & 59,737 & 69,415 & 91,406 & 99,666 \\
\hline Deposits Liabilities & 134,010 & 152,771 & 153,569 & 165,516 & 170,047 & 167,538 & 183,805 & 215,642 & 217,045 & 236,570 & 252,714 & 256,169 & 378,447 \\
\hline $\begin{array}{l}\text { Demand } \\
\text { Of which }\end{array}$ & 92,408 & 107,611 & 106,895 & 113,475 & 114,446 & 106,931 & 121,889 & 146,076 & 147,308 & 160,785 & 168,992 & 166,146 & 288,339 \\
\hline Foreign Currency Deposits & 40,672 & 46,575 & 43,155 & 46,023 & 52,261 & 46,601 & 52,708 & 55,268 & 59,424 & 73,039 & 69,831 & 71,731 & 79,836 \\
\hline Local Currency Deposits & 51,735 & 61,036 & 63,740 & 67,452 & 62,185 & 60,330 & 69,181 & 90,808 & 87,884 & 87,746 & 99,161 & 94,415 & 208,503 \\
\hline Time \& Savings Deposits & 41,602 & 45,160 & 46,674 & 52,041 & 55,601 & 60,607 & 61,916 & 69,566 & 69,737 & 75,785 & 83,722 & 90,023 & 90,108 \\
\hline Capital accounts & 48,661 & 51,387 & 57,765 & 60,975 & 66,992 & 65,013 & 71,974 & 76,176 & 84,653 & 80,365 & 82,276 & 84,301 & 79,886 \\
\hline Other items (Net) & $-13,988$ & $-35,665$ & $-27,217$ & $-38,835$ & $-29,500$ & $-25,535$ & $-34,427$ & $-45,236$ & $-34,866$ & $-40,345$ & $-40,752$ & $-33,410$ & $-20,013$ \\
\hline
\end{tabular}

Sources: Sierra Leonean authorities.

1/ Includes loans and advances

2/ Includes Claims on Non Bank Financial Institutions beginning June 1996 
Table 14. Sierra Leone: Commercial Banks Liquidity Ratios, 2001-03

\begin{tabular}{|c|c|c|c|c|c|c|c|c|c|c|c|c|}
\hline & \multicolumn{4}{|c|}{2001} & \multicolumn{4}{|c|}{2002} & \multicolumn{4}{|c|}{2003} \\
\hline & $\overline{\text { Mar }}$ & Jun & Sep & $\overline{\text { Dec }}$ & $\overline{\text { Mar }}$ & Jun & Sep & $\overline{\text { Dec }}$ & Mar & Jun & Sep & Dec \\
\hline Cash plus liquid assets & 103,019 & 97,405 & 114,207 & 108,247 & 107,089 & 110,546 & 121,306 & 136,861 & 136,145 & 135,594 & 143,516 & 127,591 \\
\hline Cash reserves & 12,353 & 12,207 & 10,546 & 17,047 & 15,539 & 11,070 & 14,933 & 21,696 & 12,818 & 13,119 & 15,946 & 20,099 \\
\hline Cash in hand & 4,762 & 4,522 & 4,435 & 9,785 & 6,550 & 6,857 & 7,915 & 10,579 & 7,703 & 9,672 & 10,296 & 11,140 \\
\hline Deposits in central bank & 7,591 & 7,685 & 6,111 & 7,262 & 8,989 & 4,213 & 7,018 & 11,117 & 5,115 & 3,447 & 5,650 & 8,959 \\
\hline Liquid assets (Treasury Bills only) & 90,666 & 85,198 & 103,661 & 91,200 & 91,550 & 99,476 & 106,373 & 115,165 & 123,327 & 122,475 & 127,570 & 107,492 \\
\hline Overall liquidity ratio & 110.4 & 91.7 & 103.4 & 90.6 & 90.9 & 91.4 & 92.5 & 85.3 & 86.4 & 82.9 & 78.5 & 69.2 \\
\hline Cash reserves & 13.2 & 11.5 & 9.6 & 14.3 & 13.2 & 9.2 & 11.4 & 13.5 & 8.1 & 8.0 & 8.7 & 10.9 \\
\hline Cash in hand & 5.1 & 4.3 & 4.0 & 8.2 & 5.6 & 5.7 & 6.0 & 6.6 & 4.9 & 5.9 & 5.6 & 6.0 \\
\hline Deposits in central bank & 8.1 & 7.2 & 5.5 & 6.1 & 7.6 & 3.5 & 5.4 & 6.9 & 3.2 & 2.1 & 3.1 & 4.9 \\
\hline Liquid assets & 97.1 & 80.2 & 93.9 & 76.3 & 77.7 & 82.3 & 81.1 & 71.8 & 78.2 & 74.9 & 69.8 & 58.3 \\
\hline Required liquidity & 41.4 & 41.8 & 42.3 & 41.4 & 41.2 & 40.9 & 41.3 & 42.2 & 42.0 & 41.7 & 41.9 & 41.3 \\
\hline Cash & 10.0 & 10.0 & 10.0 & 10.0 & 10.0 & 10.0 & 10.0 & 10.0 & 10 & 10 & 10 & 10 \\
\hline Liquid assets & 31.4 & 31.8 & 32.3 & 31.4 & 31.2 & 30.9 & 31.3 & 32.2 & 32.0 & 31.7 & 31.9 & 31.3 \\
\hline Excess/deficiency (cash) & 5,618 & 12,113 & 2,391 & 6,497 & 6,520 & 5,536 & 3,083 & 8,592 & 1,175 & $(1,228)$ & $(1,369)$ & 1,870 \\
\hline \multicolumn{13}{|l|}{ Memorandum items: } \\
\hline Total deposit liabilities $1 /$ & 93,341 & 106,211 & 110,414 & 119,493 & 117,786 & 120,931 & 131,097 & 160,374 & 157,621 & 163,532 & 182,883 & 184,438 \\
\hline Demand & 51,735 & 61,036 & 63,740 & 67,452 & 62,185 & 60,330 & 69,181 & 90,808 & 87,884 & 87,747 & 99,161 & 94,415 \\
\hline Time and savings & 41,606 & 45,175 & 46,674 & 52,041 & 55,601 & 60,601 & 61,916 & 69,566 & 69,737 & 75,785 & 83,722 & 90,023 \\
\hline
\end{tabular}

Source: Bank of Sierra Leone 
Table 15. Sierra Leone: Monetary Survey and Summary Accounts of the Bank of Sierra Leone, 2001-03 (In millions of leones)

\begin{tabular}{|c|c|c|c|c|c|c|c|c|c|c|c|c|}
\hline \multirow[b]{2}{*}{ End of Period } & \multicolumn{4}{|c|}{2001} & \multicolumn{4}{|c|}{2002} & \multicolumn{4}{|c|}{2003} \\
\hline & Mar & Jun & Sep & $\mathrm{Dec}$ & Mar & Jun & Sep & Dec & Mar & Jun & Sep & Dec \\
\hline Foreign assets (net) & $-181,010$ & $-196,048$ & $-232,886$ & $-202,278$ & $-170,204$ & $-199,064$ & $-190,720$ & $-140,521$ & $-157,820$ & $-158,340$ & $-134,331$ & $-195,880$ \\
\hline Bank of Sierra Leone & $-227,856$ & $-242,669$ & $-277,472$ & $-249,573$ & $-234,472$ & $-251,466$ & $-248,592$ & $-198,904$ & $-220,558$ & $-234,953$ & $-209,437$ & $-274,719$ \\
\hline Commercial banks & 46,846 & 46,621 & 44,586 & 47,295 & 64,268 & 52,402 & 57,872 & 58,383 & 62,738 & 76,613 & 75,106 & 78,839 \\
\hline Net domestic assets & 420,373 & 455,969 & 496,841 & 493,142 & 471,666 & 501,952 & 509,107 & 517,359 & 535,064 & 562,253 & 565,544 & 655,213 \\
\hline Domestic credit & 735,833 & 757,128 & 774,488 & 774,627 & 766,750 & 799,120 & 800,910 & 795,930 & 815,861 & 830,089 & 805,325 & 880,963 \\
\hline Claims on government (net) & 694,512 & 707,727 & 733,796 & 727,016 & 714,333 & 746,017 & 743,053 & 721,414 & 738,320 & 753,596 & 720,765 & 769,255 \\
\hline Claims on private sector $1 /$ & 41,321 & 49,401 & 40,692 & 47,611 & 52,417 & 53,103 & 57,857 & 74,516 & 77,541 & 76,493 & 84,560 & 111,708 \\
\hline Other Items Net & $-315,460$ & $-301,159$ & $-277,647$ & $-281,485$ & $-295,084$ & $-297,168$ & $-291,803$ & $-278,571$ & $-280,797$ & $-267,836$ & $-239,781$ & $-225,750$ \\
\hline Money and quasi money (M2) $2 /$ & 239,363 & 259,921 & 263,955 & 290,864 & 301,462 & 302,888 & 318,387 & 376,838 & 377,244 & 403,913 & 431,213 & 459,333 \\
\hline Money & 153,496 & 162,590 & 167,997 & 189,437 & 191,173 & 191,105 & 199,492 & 247,478 & 244,501 & 251,257 & 273,380 & 292,950 \\
\hline Currency & 97,003 & 96,142 & 98,316 & 116,153 & 121,380 & 123,154 & 121,237 & 148,015 & 150,584 & 153,540 & 161,396 & 188,448 \\
\hline Demand deposits & 56,493 & 66,448 & 69,681 & 73,284 & 69,793 & 67,951 & 78,255 & 99,463 & 93,917 & 97,717 & 111,984 & 104,502 \\
\hline Quasi money 2/ & 85,867 & 97,331 & 95,958 & 101,427 & 110,289 & 111,783 & 118,895 & 129,360 & 132,743 & 152,656 & 157,833 & 166,383 \\
\hline \multicolumn{13}{|l|}{ Balance sheet of the Bank of Sierra Leone } \\
\hline Reserve money & 112,866 & 110,467 & 113,173 & 142,103 & 143,591 & 142,965 & 144,810 & 177,441 & 169,534 & 178,812 & 192,483 & 217,217 \\
\hline Net international reserves & $-227,856$ & $-242,699$ & $-277,472$ & $-249,573$ & $-234,472$ & $-251,466$ & $-248,592$ & $-198,904$ & $-220,558$ & $-234,953$ & $-209,437$ & $-274,719$ \\
\hline Net domestic assets & 340,717 & 338,352 & 385,797 & 401,290 & 385,179 & 425,926 & 432,048 & 430,532 & 430,968 & 498,043 & 500,189 & 608,561 \\
\hline Net claims on government & 612,018 & 624,748 & 634,866 & 637,163 & 627,737 & 645,779 & 638,214 & 612,623 & 621,094 & 636,455 & 602,811 & 670,622 \\
\hline Government Securities Issued obo BSL & $\ldots$ & $\ldots$ & $\ldots$ & & 532,025 & 532,025 & 532,025 & 532,025 & 531,607 & 531,037 & 531,037 & 531,037 \\
\hline Treasury Bills & $\ldots$ & $\ldots$ & $\ldots$ & $\ldots$ & 43,588 & 38,592 & 34,073 & 33,597 & 35,437 & 34,456 & 35,423 & 65,610 \\
\hline Treasury Bearer Bonds & $\ldots$ & $\ldots$ & $\ldots$ & $\ldots$ & 10,426 & 9,588 & 8,334 & 12,101 & 9,367 & 9,876 & 11,876 & 17,219 \\
\hline Ways and Means Advances & $\ldots$ & $\ldots$ & $\ldots$ & $\ldots$ & 77,682 & 112,242 & 135,664 & 74,279 & 116,561 & 145,509 & 38,263 & 68,110 \\
\hline Government Departments & $\ldots$ & $\ldots$ & $\ldots$ & $\ldots$ & 0 & 0 & 0 & 0 & 756 & 941 & 0 & 0 \\
\hline Government Deposits & & & & & 35,984 & 46,669 & 71,883 & 39,379 & 72,634 & 85,365 & 13,788 & 11,354 \\
\hline Other items (net) & $-271,301$ & $-286,396$ & $-249,069$ & $-235,873$ & $-242,558$ & $-219,853$ & $-206,166$ & $-182,091$ & $-190,126$ & $-138,412$ & $-102,622$ & $-62,061$ \\
\hline Revaluation adjustment & 5 & 14,814 & 4,848 & $-9,614$ & $-7,116$ & $-31,495$ & $-38,646$ & $-54,187$ & $-40,876$ & $-84,278$ & $-98,269$ & $-116,625$ \\
\hline Memorandum items: & \multicolumn{12}{|c|}{ (In percent; unless otherwise indicated) } \\
\hline Money multiplier (M2/RM) & 2.1 & 2.4 & 2.3 & 2.0 & 2.1 & 2.2 & 2.2 & 2.1 & 2.2 & 2.3 & 2.2 & 2.1 \\
\hline Claims on government/Domestic credit & 94.4 & 93.5 & 94.7 & 93.9 & 93.2 & 93.4 & 92.8 & 90.6 & 90.5 & 90.8 & 89.5 & 87.3 \\
\hline Reserve money/Broad money & 47.2 & 42.5 & 42.9 & 48.9 & 47.6 & 47.2 & 45.5 & 47.1 & 44.9 & 44.3 & 44.6 & 47.3 \\
\hline Currency/Deposits & 103.9 & 90.5 & 89.0 & 97.2 & 103.1 & 101.8 & 92.5 & 92.3 & 95.5 & 93.9 & 88.3 & 102.2 \\
\hline Bank Reserves/Deposits & 13.2 & 11.5 & 9.6 & 14.3 & 13.2 & 9.2 & 11.4 & 13.5 & 8.1 & 8.0 & 8.7 & 10.9 \\
\hline Liquid assets/Deposits & 110.4 & 91.7 & 103.4 & 90.6 & 90.9 & 91.4 & 92.5 & 85.3 & 86.4 & 82.9 & 78.5 & 69.2 \\
\hline Broad money (year-on-year) & 28.3 & 33.3 & 31.8 & 33.7 & 25.9 & 16.5 & 20.6 & 29.6 & 25.1 & 33.4 & 35.4 & 21.9 \\
\hline Reserve money (year-on-year) & 16.6 & 11.4 & 25.2 & 29.4 & 27.2 & 29.4 & 28.0 & 24.9 & 18.1 & 25.1 & 32.9 & 22.4 \\
\hline \multicolumn{13}{|c|}{ Contributions to the year-on-year growth in broad money } \\
\hline Net foreign assets & 58.0 & 33.6 & 21.9 & -10.8 & 4.5 & -1.2 & 16.0 & 21.2 & 4.1 & 13.4 & 17.7 & -14.7 \\
\hline Net domestic assets & -29.7 & -0.3 & 9.9 & 44.4 & 21.4 & 17.7 & 4.6 & 8.3 & 21.0 & 19.9 & 17.7 & 36.6 \\
\hline Net credit to the government & 48.3 & 10.2 & 9.4 & 20.0 & 8.3 & 14.7 & 3.5 & -1.9 & 8.0 & 2.5 & -7.0 & 12.7 \\
\hline Credit to the rest of the economy & 5.6 & 7.0 & 3.2 & 3.3 & 4.6 & 1.4 & 6.5 & 9.3 & 8.3 & 7.7 & 8.4 & 9.9 \\
\hline
\end{tabular}


Table 16. Sierra Leone: Disbribution of Commercial Bank Loans and Advances by Major Sectors, March 2001-December 2003 (In percent, end of period)

\begin{tabular}{|c|c|c|c|c|c|c|c|c|c|c|c|c|}
\hline & \multicolumn{4}{|c|}{2001} & \multicolumn{4}{|c|}{2002} & \multicolumn{4}{|c|}{2003} \\
\hline & Mar & Jun & Sep & $\overline{\text { Dec }}$ & Mar & Jun & Sep & $\overline{\text { Dec }}$ & Mar & Jun & Sep & $\overline{\text { Dec }}$ \\
\hline Commerce and Finance & 42.38 & 42.03 & 44.62 & 44.7 & 44.7 & 45.6 & 35.5 & 43.3 & 37.9 & 39.3 & 40.0 & 35.5 \\
\hline Construction & 14.45 & 14.01 & 10.38 & 10.7 & 13.5 & 12.7 & 14.8 & 15.6 & 15.1 & 15.7 & 16.6 & 17.0 \\
\hline Manufacturing & 11.55 & 8.5 & 10.06 & 10.0 & 11.8 & 7.9 & 7.3 & 8.1 & 8.8 & 11.4 & 12.8 & 21.5 \\
\hline Agriculture, forestry, and fishing & 4.19 & 4.43 & 4.57 & 8.3 & 3.9 & 3.4 & 2.1 & 1.1 & 1.0 & 1.7 & 2.3 & 1.7 \\
\hline Mining and quarrying & 0.17 & 0.17 & 0.16 & 0.1 & 0.1 & 0.6 & 0.4 & 0.3 & 0.2 & 0.4 & 0.9 & 0.2 \\
\hline Other $1 /$ & 27.26 & 30.86 & 30.21 & 26.20 & 26.0 & 29.80 & 39.90 & 31.50 & 37.10 & 31.50 & 27.40 & 24.00 \\
\hline Total & 100 & 100 & 100 & 100 & 100 & 100 & 100 & 100 & 100 & 100 & 100 & 100 \\
\hline
\end{tabular}

Source: Bank of Sierra Leone

1/ Includes the following: a) Electricity, gas, and water; b) Transport, storage, and communication; c) Services; and d) Miscellaneous. 
Table 17. Sierra Leone: Structure of Interest Rates, March 2001- March 2004

\begin{tabular}{|c|c|c|c|c|c|c|c|c|c|c|c|c|c|}
\hline & \multicolumn{4}{|c|}{2001} & \multicolumn{4}{|c|}{2002} & \multicolumn{4}{|c|}{2003} & \multirow{2}{*}{$\frac{2004}{\text { March }}$} \\
\hline & March & June & Sept & $\overline{\text { Dec }}$ & March & June & Sept & $\overline{\text { Dec }}$ & March & June & Sept & $\overline{\mathrm{Dec}}$ & \\
\hline & \multicolumn{13}{|c|}{ (In percent per annum) } \\
\hline \multicolumn{14}{|l|}{ Lending rates } \\
\hline Treasury bills $1 /$ & & & & & & & & & & & & & \\
\hline $\begin{array}{l}\text { Ordinary 2/ } \\
\text { Special 3/ }\end{array}$ & $\begin{array}{r}11.13 \\
\ldots\end{array}$ & $\begin{array}{r}14.71 \\
\ldots\end{array}$ & $\begin{array}{r}14.45 \\
\ldots\end{array}$ & $\begin{array}{r}14.74 \\
\ldots\end{array}$ & $\begin{array}{r}15.04 \\
\ldots\end{array}$ & $\begin{array}{r}15.29 \\
\ldots\end{array}$ & $\begin{array}{r}15.23 \\
\ldots\end{array}$ & $\begin{array}{r}14.99 \\
\ldots\end{array}$ & $\begin{array}{r}15.17 \\
\ldots\end{array}$ & $\begin{array}{r}14.94 \\
\ldots\end{array}$ & $\begin{array}{r}14.88 \\
\ldots\end{array}$ & $\begin{array}{r}20.20 \\
\ldots\end{array}$ & 26.53 \\
\hline Treasury Bearer Bonds 4/ & 15.38 & 15.38 & 20.00 & 20.00 & 20.00 & 19.00 & 18.00 & 18.00 & 17.00 & 15.00 & 15.00 & 17.00 & 25.00 \\
\hline Commercial banks' prime rate $5 /$ & 25.00 & 25.00 & 24.00 & 23.00 & 22.00 & 23.00 & 21.00 & 20.00 & 20.00 & 20.00 & 20.00 & 20.00 & 20.00 \\
\hline \multicolumn{14}{|l|}{ Deposit rates 6/ } \\
\hline \multicolumn{14}{|c|}{ Time deposits with commercial banks } \\
\hline Up to one month & 6.80 & 6.80 & 6.80 & 7.30 & 7.33 & 7.33 & 7.50 & 7.50 & 7.50 & 7.50 & 7.50 & 7.50 & 7.50 \\
\hline $1-3$ months & 7.50 & 7.20 & 7.20 & 8.10 & 8.10 & 8.10 & 8.42 & 8.42 & 8.42 & 8.42 & 8.42 & 8.42 & 9.17 \\
\hline 3-6 months & 8.40 & 8.10 & 8.10 & 9.20 & 9.20 & 9.20 & 9.67 & 9.67 & 9.67 & 9.67 & 9.67 & 9.67 & 10.43 \\
\hline 6-9 months & 8.30 & 8.00 & 8.00 & 9.50 & 9.50 & 9.50 & 9.50 & 9.50 & 9.50 & 9.50 & 9.50 & 9.50 & 10.63 \\
\hline 9-12 months & 9.70 & 9.50 & 9.50 & 11.10 & 11.13 & 11.13 & 11.50 & 11.50 & 11.50 & 11.50 & 11.50 & 11.50 & 12.40 \\
\hline $12-18$ months & $\ldots$ & $\ldots$ & $\ldots$ & $\ldots$ & $\ldots$ & $\ldots$ & $\ldots$ & $\ldots$ & $\ldots$ & $\ldots$ & $\ldots$ & $\ldots$ & $\cdots$ \\
\hline $18-24$ months & $\ldots$ & $\ldots$ & $\ldots$ & $\ldots$ & $\ldots$ & $\ldots$ & $\ldots$ & $\ldots$ & $\ldots$ & $\ldots$ & $\ldots$ & $\ldots$ & $\ldots$ \\
\hline Savings deposits & 5.47 & 4.50 & 4.50 & 4.83 & 5.10 & 5.10 & 5.50 & 5.50 & 5.50 & 5.50 & 5.50 & 5.50 & 6.37 \\
\hline
\end{tabular}

Source: Data provided by the Sierra Leonean authorities.

1/ Annual rate equivalent. Ordinary 91-day treasury bills are sold to banks and other financial and non financial institutions, while special treasury Bills are sold to the non the non bank public. Both are zero coupon bills issued at a discount to face value

2/ Since late January 1992, rates on ordinary treasury bills have been market determined at weekly auctions by the Bank of Sierra Leone with commercial banks.

3/ As of August 1992, the treasury bill market was unified and the issuance of special treasury bills discontinued.

4/ Annual effective yield on the latest issue. One year bearer bonds introduced in August 1993. Sold at fixed coupon rate of interest until March 1995, when an auction system was introduced.

5/ Lending rates have been freely determined by commercial banks since April 1990.

6/ Deposit rates have been freely determined by commercial banks since August 16, 1993. Prior to that date, the Bank of Sierra Leone administered minimum deposit rates. 
Table 18. Sierra Leone: List of Commercial Banks, as at end 2003

(In millions of leones; unless otherwise indicated)

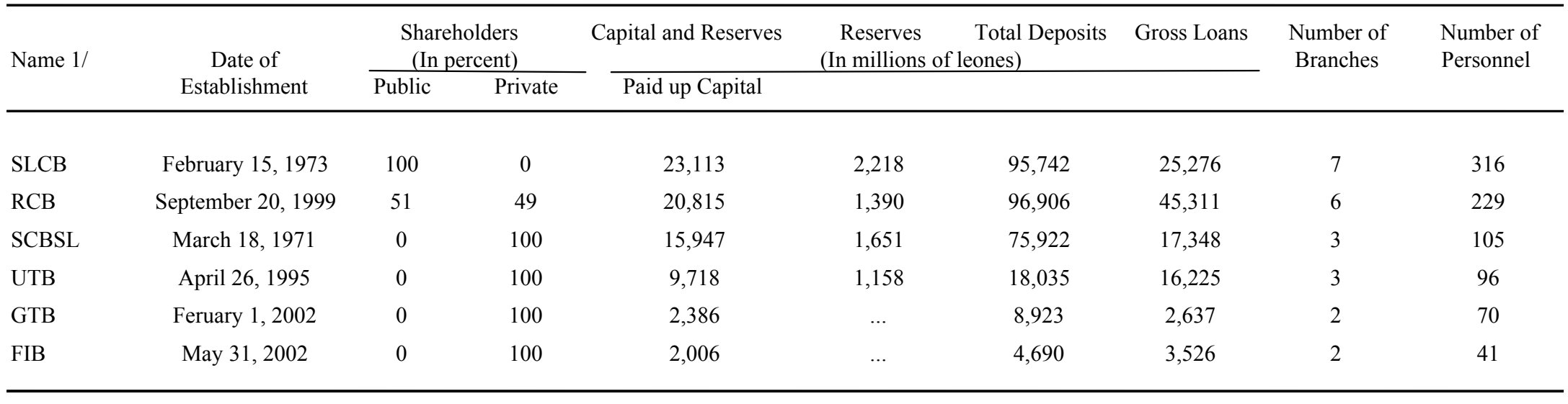

Source: Bank of Sierra Leone

1/ SLCB - Sierra Leone Commercial Bank Limited

RCB - Rokel Commercial Bank (SL) Limited

SCBSL - Standard Chartered Bank Sierra Leone Limited

UTB - Union Trust Bank Limited

GTB - Guaranty Trust Bank imited Limited

FIB - First International Bank Limited 
Table 19. Sierra Leone: Exchange Rate Developments, 1990-2003

\begin{tabular}{|c|c|c|c|c|c|c|c|}
\hline \multirow[b]{2}{*}{1990} & & \multicolumn{2}{|c|}{$\begin{array}{l}\text { Real effective exchange rate } \\
(1990=100) \\
\text { (period average) (end-period) }\end{array}$} & \multicolumn{2}{|c|}{$\begin{array}{l}\text { Jominal effective exchange rate } \\
\quad(1990=100) \quad(1990=100) \\
(\text { period average })(\text { end-period })\end{array}$} & \multicolumn{2}{|c|}{ Leones per U.S. dollar } \\
\hline & & 100.0 & 96.9 & 100.0 & 76.2 & 151.4 & 188.7 \\
\hline 1991 & & 101.3 & 91.6 & 55.8 & 36.9 & 295.3 & 434.8 \\
\hline 1992 & & 92.3 & 97.2 & 32.5 & 32.5 & 499.4 & 526.3 \\
\hline 1993 & & 102.9 & 114.5 & 33.3 & 34.9 & 567.5 & 577.6 \\
\hline 1994 & & 117.6 & 116.1 & 35.1 & 33.6 & 586.7 & 613.0 \\
\hline 1995 & & 106.3 & 92.5 & 26.7 & 20.7 & 755.2 & 934.2 \\
\hline 1996 & & 107.4 & 103.4 & 22.1 & 22.6 & 920.7 & 918.9 \\
\hline 1997 & & 123.2 & 128.9 & 23.0 & 17.3 & 981.5 & 1261.2 \\
\hline 1998 & & 105.9 & 94.0 & 14.6 & 13.7 & 1563.6 & 1604.7 \\
\hline 1999 & & 123.6 & 96.6 & 12.9 & 10.5 & 1804.2 & 2141.2 \\
\hline 2000 & & 112.0 & 124.3 & 12.0 & 14.6 & 2092.1 & 1666.7 \\
\hline 2001 & & 123.1 & 110.8 & 13.1 & 12.0 & 2099.0 & 2161.3 \\
\hline 2002 & & 108.7 & 100.1 & 12.2 & 11.3 & 2099.0 & 2191.7 \\
\hline 2003 & & 91.5 & 82.8 & 9.8 & 8.5 & 2347.9 & 2562.2 \\
\hline \multirow[t]{4}{*}{2000} & Q1 & 94.4 & 97.9 & 10.1 & 10.3 & 2328.9 & 2260.6 \\
\hline & Q2 & 118.5 & 116.1 & 12.3 & 12.3 & 2000.4 & 2005.9 \\
\hline & Q3 & 110.8 & 112.0 & 11.9 & 12.0 & 2105.8 & 2098.7 \\
\hline & Q4 & 124.3 & 112.0 & 13.5 & 14.6 & 1933.5 & 1666.7 \\
\hline \multirow[t]{4}{*}{2001} & Q1 & 123.5 & 126.6 & 13.8 & 13.6 & 1782.0 & 1886.8 \\
\hline & Q2 & 131.7 & 132.8 & 13.9 & 13.8 & 1915.8 & 1967.0 \\
\hline & Q3 & 124.5 & 121.3 & 12.8 & 12.6 & 2054.1 & 2091.0 \\
\hline & Q4 & 112.7 & 110.8 & 12.0 & 12.0 & 2192.7 & 2161.3 \\
\hline \multirow[t]{4}{*}{2002} & Q1 & 112.7 & 109.5 & 12.7 & 12.4 & 2107.8 & 2165.3 \\
\hline & Q2 & 111.7 & 114.0 & 12.4 & 12.6 & 2084.7 & 2035.0 \\
\hline & Q3 & 107.8 & 105.4 & 12.1 & 12.0 & 2068.5 & 2093.7 \\
\hline & Q4 & 102.8 & 100.1 & 11.7 & 11.3 & 2135.1 & 2191.7 \\
\hline \multirow[t]{4}{*}{2003} & Q1 & 96.5 & 96.4 & 10.7 & 10.5 & 2228.6 & 2257.0 \\
\hline & Q2 & 93.1 & 90.9 & 10.0 & 9.7 & 2293.4 & 2319.8 \\
\hline & Q3 & 90.7 & 87.4 & 9.6 & 9.2 & 2368.1 & 2456.4 \\
\hline & Q4 & 85.9 & 82.8 & 8.8 & 8.5 & 2501.6 & 2562.2 \\
\hline \multirow[t]{2}{*}{2004} & Q1 & 81.8 & 81.6 & 8.1 & 8.1 & 2617.1 & 2670.7 \\
\hline & Q2 & 84.3 & 84.1 & 8.2 & 8.1 & 2666.3 & 2685.1 \\
\hline \multicolumn{2}{|c|}{ Memorandum item: } & \multicolumn{6}{|c|}{ (Annual percentage change) } \\
\hline 1990 & & -25.5 & -40.1 & -58.3 & -65.1 & 153.2 & 188.7 \\
\hline 1991 & & 1.3 & -5.5 & -44.2 & -51.6 & 95.0 & 130.4 \\
\hline 1992 & & -8.8 & 6.1 & -41.6 & -11.8 & 69.1 & 21.1 \\
\hline 1993 & & 11.4 & 17.9 & 2.4 & 7.3 & 13.6 & 9.8 \\
\hline 1994 & & 14.4 & 1.4 & 5.4 & -3.7 & 3.4 & 6.1 \\
\hline 1995 & & -9.6 & -20.3 & -23.8 & -38.4 & 28.7 & 52.4 \\
\hline 1996 & & 1.0 & 11.8 & -17.3 & 9.1 & 21.9 & -1.6 \\
\hline 1997 & & 14.8 & 24.6 & 4.1 & -23.3 & 6.6 & 37.2 \\
\hline 1998 & & -14.1 & -27.0 & -36.8 & -21.2 & 59.3 & 27.2 \\
\hline 1999 & & 16.8 & 2.8 & -11.7 & -23.5 & 15.4 & 33.4 \\
\hline 2000 & & -9.4 & 28.6 & -7.0 & 39.3 & 16.0 & -22.2 \\
\hline 2001 & & 9.9 & -10.8 & 9.7 & -17.9 & 0.3 & 29.7 \\
\hline 2002 & & -11.7 & -9.7 & -6.9 & -5.5 & 0.0 & 1.4 \\
\hline 2003 & & -15.8 & -17.2 & -20.0 & -24.9 & 11.9 & 16.9 \\
\hline
\end{tabular}

Sources: Data provided by the Sierra Leonean authorities; IFS, RETS; and IMF Information Notice System. 
Table 20. Sierra Leone: Values, Volumes, and Unit Values of Major Commodity Exports, 1998-2003

\begin{tabular}{|c|c|c|c|c|c|c|}
\hline & 1998 & 1999 & 2000 & 2001 & 2002 & 2003 \\
\hline & \multicolumn{6}{|c|}{ (In millions of U.S. dollars; unless otherwise indicated) } \\
\hline \multicolumn{7}{|c|}{ 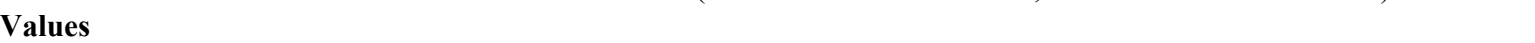 } \\
\hline Total exports & 6.6 & 6.3 & 12.9 & 20.3 & 48.6 & 92.4 \\
\hline Domestic exports & 6.3 & 4.5 & 12.0 & 19.9 & 46.3 & 84.0 \\
\hline Minerals & 1.8 & 2.7 & 10.1 & 19.6 & 41.7 & 76.7 \\
\hline Bauxite & 0.0 & 0.0 & 0.0 & 0.0 & 0.0 & 0.0 \\
\hline Diamonds 1/ & 1.8 & 1.3 & 10.1 & 19.6 & 41.7 & 76.7 \\
\hline Gold & .. & 0.0 & 0.0 & 0.0 & 0.0 & 0.0 \\
\hline Illeminite & 0.0 & 0.2 & 0.0 & 0.0 & 0.0 & 0.0 \\
\hline Rutile & 0.0 & 1.2 & 0.0 & 0.0 & 0.0 & 0.0 \\
\hline Agricultural commodities & 2.8 & 1.4 & 0.9 & 0.3 & 1.5 & 2.6 \\
\hline Cocoa beans & 1.4 & 0.6 & 0.3 & 0.3 & 1.2 & 2.6 \\
\hline Coffee & 1.1 & 0.7 & 0.6 & $\ldots$ & 0.3 & $\ldots$ \\
\hline Other & 0.3 & 0.1 & 0.0 & 0.0 & $\ldots$ & $\ldots$ \\
\hline $\begin{array}{l}\text { Fish shrimps, and other } \\
\text { fishery products }\end{array}$ & 0.1 & 0.0 & 0.0 & 0.0 & $\cdots$ & $\cdots$ \\
\hline Other exports & 1.6 & 0.5 & 1.0 & 0.0 & 3.1 & 4.7 \\
\hline Reexports & 0.3 & 1.8 & 0.9 & 0.4 & 2.3 & 8.4 \\
\hline \multicolumn{7}{|l|}{ Volumes } \\
\hline \multicolumn{7}{|l|}{ Minerals } \\
\hline Bauxite (thousands of tons) & 0.0 & 0.0 & 0.0 & 0.0 & 0.0 & 0.0 \\
\hline Diamonds (thousands of carats) & 16.0 & 9.0 & 77.3 & 224.5 & 351.7 & 506.8 \\
\hline Gold (thousands of ounces) & $\ldots$ & 0.0 & 0.0 & $\ldots$ & 0.0 & 0.0 \\
\hline Rutile (thousands of tons) & 0.0 & 4.8 & 0.0 & 0.0 & 0.0 & 0.0 \\
\hline \multicolumn{7}{|l|}{ Agricultural commodities } \\
\hline Cocoa (thousands of tons) & 2.4 & 1.3 & 1.4 & 0.6 & 1.2 & 2.7 \\
\hline Coffee (thousands of tons) & 1.8 & 1.2 & 2.0 & 0.1 & 0.9 & 0.1 \\
\hline \multicolumn{7}{|l|}{ Unit values } \\
\hline \multicolumn{7}{|l|}{ Minerals } \\
\hline Bauxite (tons) & $\ldots$ & $\ldots$ & $\ldots$ & $\ldots$ & $\ldots$ & $\ldots$ \\
\hline Diamonds (carats) & 112.0 & 139.0 & 130.7 & 87.3 & 118.6 & 151.3 \\
\hline Gold (ounces) & 277.0 & $\ldots$ & $\ldots$ & $\ldots$ & $\ldots$ & $\ldots$ \\
\hline Rutile (tons) & $\cdots$ & 243.0 & $\cdots$ & $\cdots$ & $\cdots$ & $\cdots$ \\
\hline \multicolumn{7}{|l|}{ Agricultural commodities } \\
\hline Cocoa beans (tons) & 598.0 & 427.0 & 214.3 & 500.0 & $1,000.0$ & 963.0 \\
\hline Coffee (tons) & 601.0 & 600.0 & 300.0 & 305.7 & 333.3 & 354.9 \\
\hline \multicolumn{7}{|l|}{ Memorandum items: } \\
\hline \multicolumn{7}{|l|}{ Value of total exports } \\
\hline In millions of SDRs & 4.9 & 4.6 & 8.5 & $\ldots$ & $\ldots$ & $\ldots$ \\
\hline In millions of Leones & $10,318.0$ & $11,342.0$ & $26,771.0$ & $57,898.3$ & $102,009.7$ & $217,742.7$ \\
\hline
\end{tabular}

Source: Bank of Sierra Leone.

1/ Reflects only official exports. 
Table 21. Sierra Leone: Values, Volumes, and Unit Values of Major Groups of Commodity Imports, 1998-2003

\begin{tabular}{|c|c|c|c|c|c|c|}
\hline & 1998 & 1999 & 2000 & 2001 & 2002 & 2003 \\
\hline & \multicolumn{6}{|c|}{ (In millions of U.S. dollars) } \\
\hline \multicolumn{7}{|l|}{ Values (c.i.f.) } \\
\hline Total Imports $1 /$ & 95.6 & 79.4 & 145.9 & 183.6 & 264.3 & 303.7 \\
\hline Foodstuffs & 36.0 & 27.8 & 45.3 & 51.9 & 70.8 & 74.5 \\
\hline \multicolumn{7}{|l|}{ Of which } \\
\hline Rice & 25.7 & 16.6 & 22.1 & 23.6 & 27.3 & 28.6 \\
\hline Beverages and tobacco & 3.9 & 3.2 & 4.8 & 4.9 & 11.3 & 11.0 \\
\hline Animal and vegetable oils & 2.2 & 1.1 & 2.3 & 1.6 & 2.8 & 2.2 \\
\hline Crude materials & 2.7 & 2.9 & 4.7 & 5.8 & 9.2 & 6.9 \\
\hline Minerals, fuels, and lubricants & 23.2 & 19.7 & 39.4 & 43.3 & 51.7 & 78.2 \\
\hline Crude petroleum & - & - & - & - & 0.0 & 0.0 \\
\hline Petroleum products & 23.2 & 19.7 & 39.4 & 43.3 & 51.7 & 78.2 \\
\hline Chemicals & 7.6 & 8.0 & 12.7 & 8.5 & 18.3 & 19.3 \\
\hline Manufactured products classified by material & 8.5 & 5.9 & 13.3 & 21.5 & 35.9 & 42.2 \\
\hline Machinery and transportation equipment & 8.6 & 7.5 & 18.6 & 37.2 & 50.2 & 56.4 \\
\hline \multirow[t]{2}{*}{ Miscellaneous manufactured articles } & 2.9 & 3.3 & 4.8 & 8.9 & 14.0 & 13.0 \\
\hline & \multicolumn{6}{|c|}{ (In thousands of tons) } \\
\hline \multicolumn{7}{|l|}{ Volumes } \\
\hline Rice & 88.0 & 69.0 & 101.5 & 132.2 & 146.4 & 156.7 \\
\hline Petroleum & 87.0 & 49.0 & 105.7 & 137.5 & 169.3 & 185.6 \\
\hline & \multicolumn{6}{|c|}{ (In U.S. dollars per ton) } \\
\hline \multicolumn{7}{|l|}{ Unit values (c.i.f.) } \\
\hline Rice & 292.0 & 240.6 & 217.7 & 178.5 & 186.5 & 182.5 \\
\hline Petroleum & 266.7 & 402.0 & 372.8 & 314.9 & 305.4 & 421.3 \\
\hline
\end{tabular}

Source: Bank of Sierra Leone.

1/ Excludes imports associated with proceeds from unrecorded diamond exports. 
Table 22. Sierra Leone: External Public Debt and Publicly Guaranteed Debt, 1998-2003 (In millions of U.S. dollars)

\begin{tabular}{|c|c|c|c|c|c|c|}
\hline & 1998 & 1999 & 2000 & 2001 & 2002 & 2003 \\
\hline Total Debt & $1,175.0$ & $1,226.0$ & $1,254.8$ & $1,443.6$ & $1,543.6$ & $1,637.8$ \\
\hline $\begin{array}{l}\text { Medium-and long-term } \\
\text { (disbursed only) 1/ } \\
\text { Of which }\end{array}$ & 963.0 & 999.0 & $1,029.8$ & $1,251.8$ & $1,361.2$ & $1,464.7$ \\
\hline Multilateral loans 2/ & 538.0 & 560.0 & 567.4 & 608.3 & 703.8 & 780.2 \\
\hline Bilateral loans & 338.0 & 352.0 & 346.0 & 371.3 & 406.7 & 434.7 \\
\hline Other (specify) 3/ & 87.0 & 87.0 & 116.4 & 272.2 & 250.7 & 249.8 \\
\hline Suppliers' credits & $\ldots$ & $\cdots$ & $\cdots$ & $\ldots$ & $\ldots$ & $\cdots$ \\
\hline Financial institutions & $\cdots$ & $\cdots$ & $\cdots$ & $\cdots$ & $\cdots$ & $\cdots$ \\
\hline Use of Fund credit & 195.0 & 203.0 & 192.0 & 175.8 & 174.8 & 165.7 \\
\hline $\begin{array}{l}\text { Interest in arrears on } \\
\text { medium-and long-term debt } \\
\text { Of which }\end{array}$ & 17.0 & 24.0 & 33.0 & 16.0 & 7.6 & 7.4 \\
\hline Fund charges & $\ldots$ & $\ldots$ & $\ldots$ & $\ldots$ & $\ldots$ & $\ldots$ \\
\hline To other official creditors & 17.0 & 24.0 & 33.0 & 16.0 & 7.6 & 7.4 \\
\hline To private creditors & $\cdots$ & .. & $\cdots$ & $\cdots$ & $\ldots$ & $\cdots$ \\
\hline Short-term debt 3/ & $\cdots$ & $\cdots$ & $\cdots$ & $\cdots$ & $\cdots$ & $\cdots$ \\
\hline $\begin{array}{l}\text { Memorandum items: } \\
\text { Undisbursed medium- } \\
\text { and long-term debt }\end{array}$ & 160.0 & 125.0 & 110.0 & 122.0 & $\cdots$ & $\cdots$ \\
\hline $\begin{array}{l}\text { Medium-and long-term } \\
\text { external debt }\end{array}$ & 980.0 & $1,023.0$ & $1,062.8$ & $1,267.8$ & $1,368.8$ & $1,472.1$ \\
\hline
\end{tabular}

Sources: The Bank of Sierra Leone; the World Bank; and staff estimates.

1/ Includes principal arrears.

2/ Excludes IMF

3/ Includes commercial and military debt. 
Table 23. Sierra Leone: External Payments Arrears Outstanding, 1998-2003 1/

(In millions of U.S. dollars; end of period)

\begin{tabular}{|c|c|c|c|c|c|c|}
\hline & 1998 & 1999 & 2000 & 2001 & 2002 & 2003 \\
\hline Total & 171.5 & 199.5 & 216.8 & 329.5 & 295.0 & 295.9 \\
\hline $\begin{array}{l}\text { Arrears on medium-and long-term deb } \\
\text { (not including the Fund) } \\
\text { Of which }\end{array}$ & 60.0 & 83.0 & 100.3 & 48.0 & 40.8 & 42.6 \\
\hline Multilateral loans & 18.0 & 23.0 & 18.4 & 18.4 & 10.3 & 9.6 \\
\hline Bilateral loans & 42.0 & 60.0 & 81.9 & 29.6 & 30.5 & 33.0 \\
\hline Suppliers' credits & 0.0 & 0.0 & 0.0 & 0.0 & 0.0 & 0.0 \\
\hline Financial institutions & 0.0 & 0.0 & 0.0 & 0.0 & 0.0 & 0.0 \\
\hline Arrears on commercial payments $2 /$ & 87.5 & 87.5 & 87.5 & 250.0 & 230.2 & 230.0 \\
\hline Other (military) 2/ & 24.0 & 29.0 & 29.0 & 31.5 & 24.0 & 23.3 \\
\hline
\end{tabular}

Sources: The Bank of Sierra Leone; the World Bank; and staff estimates.

1/ Excludes arrears to the Fund

2/ Includes Pipeline Arrears

3/ Includes Interest Arrears 
(All amounts in Leones)

Tax

Nature of Tax

Exemptions and Deductions

Rates

1. Taxes on net income and profits

1.1. Taxes on companies, corporations and enterprises

1.1.1. Company income

tax. Income Act

(No.1 of 1943)

amended several

times, most

recently under Act

23/72; Acts 17/77,

$8 / 78,3 / 92$,

8/2000; Decree

16/94; Surtax

(Temporary Impo-

sition) Act, 1968

$(14 / 68)$; Surtax

(Temporary

imposition) Order,

1973; Surtax

(Temporary

Imposition)

(Amendment) Act,

1976 (26/76);

Business

Registration

Amendment)

Rules, 1977

(152/77); Income

Tax (Taxation of

Rent) Rules, 1979

(22/79); and Surtax

No. 4 Order, 1981 $(16 / 81)$.
Annual tax on net accrued income of domestic companies. Foreign companies having assets or business within Sierra Leone are taxed on income from sources within Sierra Leone unless otherwise provided by treaty. Companies are allowed loss carry forward indefinitely.

A minimum chargeable income of 10 percent of turnover ( 15 percent where accounts have not been kept) applies to all companies. Where a company or business proprietorship has been audited by a "reputable firm of Accountants" and the Commissioner is satisfied with the records, no minimum chargeable income will apply and assessment will be on a profit basis.

Companies incorporated or resident in

Sierra Leone deduct tax on dividends paid to shareholders at a flat rate of 10 percent.

Payments are submitted on a quarterly basis with a final return filed after close of the financial year.

Unincorporated business make advance income tax payments in the form of a 3 percent surcharge on imports.
Exemptions apply to income earned by a cooperative society registered under the Cooperative Societies Act 1977 and

to income derived from agriculture for the first ten years from the commencement of the activity if the business is owned by an individual and the first six years if by a limited company.

All revenue expenses incurred

producing accessible income during the year of assessment are deductible.

Capital allowances are claimed on a reducing basis from the end of the $1^{\text {st }}$ year. For buildings and structures used to house industrial, manufacturing or agricultural activities the capital allowance is $15 \%$. For buildings used to house commercial activities other than above the rate of capital allowance is 10 percent. For buildings other than those described in the two categories the rate is $5 \%$.. Capital allowance for mining companies is as per the sixth schedule. Companies which maintain proper books of account and which have been audited for three years by a recognized firm of accounts and not in arrears for a previous year of

assessment is exempt from making 3\% advance income tax payment
The basic rate of company income tax is 35 percent. 
(All amounts in Leones)

Tax

\subsection{Tax on individuals}

\subsubsection{Individual income}

tax.

Income Tax Act

No.1 of 1943 ,

amended several

times, most

recently under

Acts 23/72, 17/77

$8 / 78$, and $3 / 92$

Decree 16/94;

Public Notices

33/72, 13/73,

$14 / 73,15 / 73$,

152/77, 21/79,

$22 / 79,13 / 81$

$14 / 81,15 / 81$,

$18 / 81$, and $2 / 86$;

Income tax Act

2000 and Surtax

(Temporary

Imposition) Act,

$1968(14 / 68)$,

Surtax (Temporary

Imposition) Order,

1973, and Surtax

(Temporary

Imposition

Amendment) Act,

$1976(26 / 76)$
With effect from $1 / 4 / 2000$ according to the Income Tax Act 2000 the tax is payable by residents on their world

wide income i.e. income from S.L.or outside S. L. Nonresident persons are exempt from tax on Sierra Leone source income. Currently the exemption level is LE. 800,000 .

The tax is imposed on net income, defined as difference between gross income and deductions permitted by law. Benefits in kind are included in income at the rate not exceeding the under mentioned:

\section{Year 2002/2003}

Housing allowance - Le6, 000,000 p.a.

Vehicle allowance - Le3, 000, 000 p.a

Utilities allowance- Le1,500 000,p.a.

Domestic servant Le- 450,000 each.

Year 2003/2004

Housing Le8,000,000 p.a.

Vehicle Le 4,, 000,000 p.a.

Utilities Le 2, 000,000

Domestic Servant Le 600,000 each.
Exemptions apply to the emoluments of the President, accredited ambassadors and other qualifying personnel who are resident in Sierra Leone solely for official purposes. Exemptions also apply to qualifying retirement and death benefits and interest paid or credited by the Sierra Leone Post Office Savings Bank.

Deductions from business income include all expenditures incurred to produce assessable income. These include $80 \%$ interest on borrowed capital, rent payable on land or

buildings and to acquire income, and bad or doubtful debts. There are no deductions from employment income.

There are no special personal and family allowances or reliefs, nor are there any allowances for insurance premiums.

Deduction is allowed for expenditure on insuring and managing the property while under occupation. Also on repairs , renewal alteration or improvement to the extent of $5 \%$ of the balance of the pool. Capital allowance can be claimed for any such amount in excess of 5\% of the pool.
The same schedule is applicable to resident individual in employment, business, property etc.

Another schedule is applicable for nonresident individuals in employment, business, property etc.

\section{Employment income tax rates for}

\section{PAYE in 2004}

(Income in thousands of leones)

Annual employment Marginal tax income of residents

$\begin{array}{rc}\text { 1,000,000 p.a. } & \text { Nil } \\ \text { Next 2,000,000 p.a. } & 20 \% \\ \text { Next 2,000,000 p. a. } & 25 \% \\ \text { Next 2,500,000 p.a. } & 30 \\ \text { Over 7,500,000 p..a. } & 35 \%\end{array}$

Rates of tax on chargeable income of non-residents other than income to which part II applies. $25 \%$

Rate of tax to be withheld from

payments made to non-residents: Employment income $\quad 25 \%$

Payment to contractors $\quad 10 \%$

Dividends

Interest

Rents \& Royalties $10 \%$

Pensions \& Annuities $\quad 25 \%$ Natural Resource Payments 25\% 
(All amounts in Leones)

Tax
Nature of Tax

Exemptions and Deductions

Rates

Payments to or applications

For the benefit of non-resident

Beneficiaries

1.2.1. Individual income $\operatorname{tax}$

(concluded).
Tax on wages and salaries are withheld at source under Pay-As-You-Earn.

Interest income including bank interest

and dividends is subject to a final withholding tax of $15 \%$ and $10 \%$ respectively.

A tax at the rate of 10 percent must be deducted from rents, $25 \%$ on royalties, premiums or other gains or profits

arising from property in excess of Le 30,000 per month.

A tax at the rate of $10 \%$ to be withheld

from payments made to persons

resident in Sierra Leone.

\section{Social Security contributions}

\section{Payroll taxes}

Employers' payroll tax. Payroll

Tax Act 1972 (16/72); Public

Notice 60/73; Act 9/73; Public

Notice 64/73; Public Notice

58/74; Act 16/74; Public Notice

7/81; Payroll Tax

(Amendment) Act, 1992; and

Decree 4/95.

None.
Tax is imposed on the payroll of each non-citizen employed at any time during the calendar year.
Exemptions granted include certain religious and charitable institutions, diplomatic and consular missions, and such persons as may be exempted by Ministerial Order (in practice, all Sierra Leone citizens are exempt).

Exemptions granted to employees of limited companies who own 40 percent or more of a company's share capital, or partners who own 25 percent or more.
Type of payment

\begin{tabular}{lc} 
Payment to contractors & $5 \%$ \\
Dividends & $10 \%$ \\
Interest & $15 \%$ \\
Rents & $10 \%$ \\
Royalties & $25 \%$ \\
Pensions \& annuities & $15 \%$ \\
\multicolumn{2}{c}{ Natural resource payments $25 \%$}
\end{tabular}

Le 1,000,000 and Le 100,000 for ECOWAS citizens. 
(All amounts in Leones)

Tax

Nature of Tax

Exemptions and Deductions

Rates

\section{Taxes on property}

\subsection{Real estate}

4.1.1. Urban rates

(e.g. Freetown

Municipality Act

1973, (20/73)

New Local

Government Act

2004.
Urban rates levied and collected on developed property; e.g., in the main cities such as Freetown, Bo, Kenema, Kono and Makeni. The legal incidence of the tax falls on the occupier of the property. Valuation of the property is done by the city Valuer.
4.1.2. Land taxes
Tax levied on unit size, with amount of None. tax varying by location. An initial land registration fee is also charged.
In Freetown, no rates are payable on premises that belong to, are held under lease by, or are held in trust for: (a) the Freetown Municipal Corporation; and (b) the Government of Sierra Leone. Other exemptions include premises owned by a foreign state (e.g. diplomatic missions). Discretionary exemptions (or reduced tax liabilities) may be accorded by the city council on grounds of poverty. Rates are payable whether building are occupied or not.
Two different rates are applied to urban property. They are:

(a) Commercial properties - Le $20 \mathrm{x}$ Ratable Value.

(b) Dwellings - Le 10 x Ratable Value.

Valuation is done on dwellings as follows:

(a) Modern housing (e.g., with toilet facilities) is valued at Le.5. 00 per square foot in West and Central Wards and Le4.50 per square foot in East Wards.

(b) Housing without modern facilities is valued at Le3.00 per square foot, with mud houses at Le $2 . .50$ per square foot.

Commercial properties such as wholesale and retail shops have different valuations depending on the structure and condition of operations. Valuation ranges from Le.5.00 to Le 20 per square foot.

The registration fee is Le 30,000 per transaction. Annual land taxes are:

$\underline{\text { Location }}$

Tax in Leone

(a) Western Area
(i) Western
40,000 
(All amounts in Leones)

Tax
Nature of Tax
Exemptions and Deductions

Rates
(ii) Eastern
40,000
(iii) Central
00,000
(b) Rural villages $\quad 40,000$
(c) Provincial head towns 40,000
(d) Agricultural land
2,000

\section{Taxes on goods and services}

\subsection{Sales tax}

Sales Tax Decree, 1995 (5/95).

\subsection{Selective excises on goods}

The Excise Act, 1982
A tax is levied on the ex factory price

of domestic manufactures and C.I.F.

price of imports plus duties (excise and import). Building materials and

fabricated structures, which are not

excisable, are included in the sales tax

base.

An embryonic value-added tax to

provide rebates of payments of sales tax on inputs was introduced effective July 1993.

An ad valorem tax is imposed on locally manufactured products, with the value of the goods taken to be the normal price; i.e., the open market price between independent buyer and seller, exclusive of the excise duty.

\section{Ad valorem taxes on petroleum} products were effectively eliminated in January 1994 and replaced with specific duties.
Exemptions apply on goods manufacturned in Sierra Leone that are shipped as stores for consumption outside of Sierra Leone and goods exported by the manufacturer.

Exemptions apply on goods manufacturned in Sierra Leone that are shipped as stores for consumption outside of Sierra Leone and goods exported by the manufacturer.

The Road Transport Corporation and the National Power Authority are exempted through ad hoc arrangements for their purchases of diesel fuel and fuel oil, respectively.
The rate is 17.50 percent.

The rates on all excisable goods were unified in July 1993 at 30 percent, except petroleum products and tobacco.

As of October, 2004, the per imperia gallon charges levied on petroleum products were as follows:

$\begin{array}{ll}\text { Petrol } & \text { Le } 1613.17 \\ \text { Diesel } & \text { Le } 1397.36 \\ \text { Kerosene } & \text { Le } 575.04 \\ \text { Fuel oil } & \text { Le } 238.980\end{array}$

Petrol and diesel also attract a Le 750 per 
(All amounts in Leones)

Tax

Nature of Tax

Exemptions and Deductions

Rates

imperial gallon road user charge.

\subsection{Selective excises on} services

\subsubsection{Entertainmen}

tax.

Entertainment Tax

Act, 1971 (17/71);

Act 14/72; and

Entertainment Tax

(Amend-

arrangements) Act,

$1981(7 / 81)$.

5.3.2. Restaurant tax.

\subsubsection{Foreign travel} (ticket) tax.

Foreign Travel

(Ticket) Tax Act

1975 (14/75); and

Act 52/75

\subsubsection{Tourism tax}

Tourism

development Act

(No.11), 1990.

\subsubsection{Betting tax.}

Control of Betting

and Lotteries Act

1969 (3/69),

amended 1981 .
In general, an ad valorem tax is levied

on each person upon admission to

chargeable entertainments and

recovered from the proprietor of the

entertainment. Casinos and gaming

houses are taxed on a specific per

machine basis.

Payable on the amount of all restaurant bills.

An ad valorem tax paid by every person departing by any means of transport

from Sierra Leone, on or before the date

of departure. In practice the tax is

collected mostly by airlines.

An ad valorem levy imposed on the total cost of specified services to

tourists traveling to, from, or within

Sierra Leone whether or not they are

residents of Sierra Leone. Revenue

proceeds are earmarked for use by the

National Tourism Board

A tax on all stakes and winnings from soccer pools.
Entertainment is exempted if wholly educational or provided by a nonprofit organization for educational or charitable purposes, or if not, whose proceeds from the entertainment are wholly donated to philanthropic and/or charitable purposes.

Exemptions include government officials on official duty, religious and charitable organization.

None.

$\begin{array}{ll}\text { Bed and breakfast } & 7.5 \% \\ \text { Full and half board } & 5 \% \\ \text { Land tour arrangements } & 1 \%\end{array}$

$\$ 5$ per visit

None.
10 percent of the price of admission. The specific casino-related tax rates are as follows:

Government levy Le $750 \underline{\text { per machine }}$

License fee per year
10 percent of all restaurant bills.

10 percent of the fare for a one-way trip and 20 percent for the return trip. Royalty on visit to Bunce

Island.

30 percent. 
(All amounts in Leones)

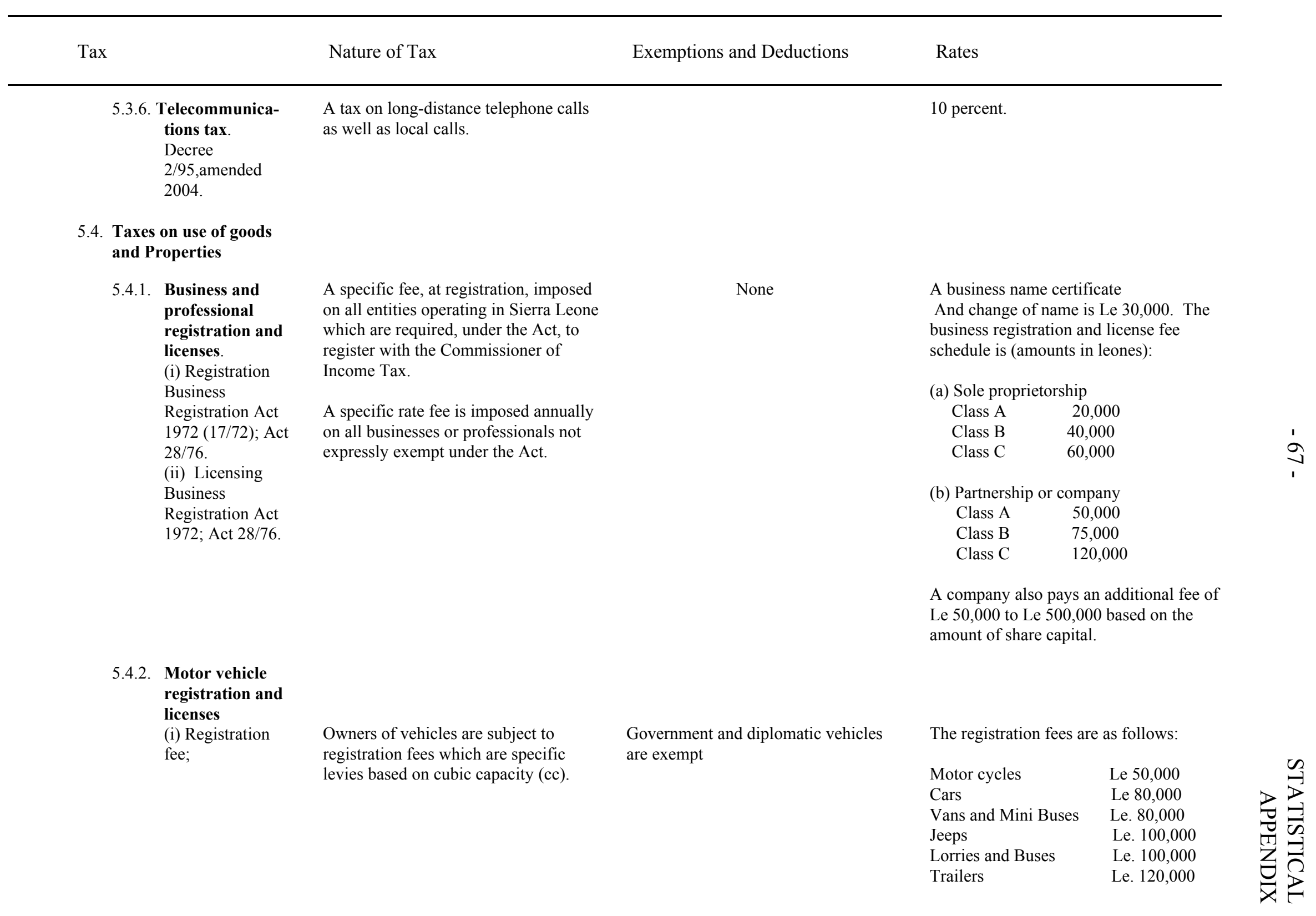


(All amounts in Leones)

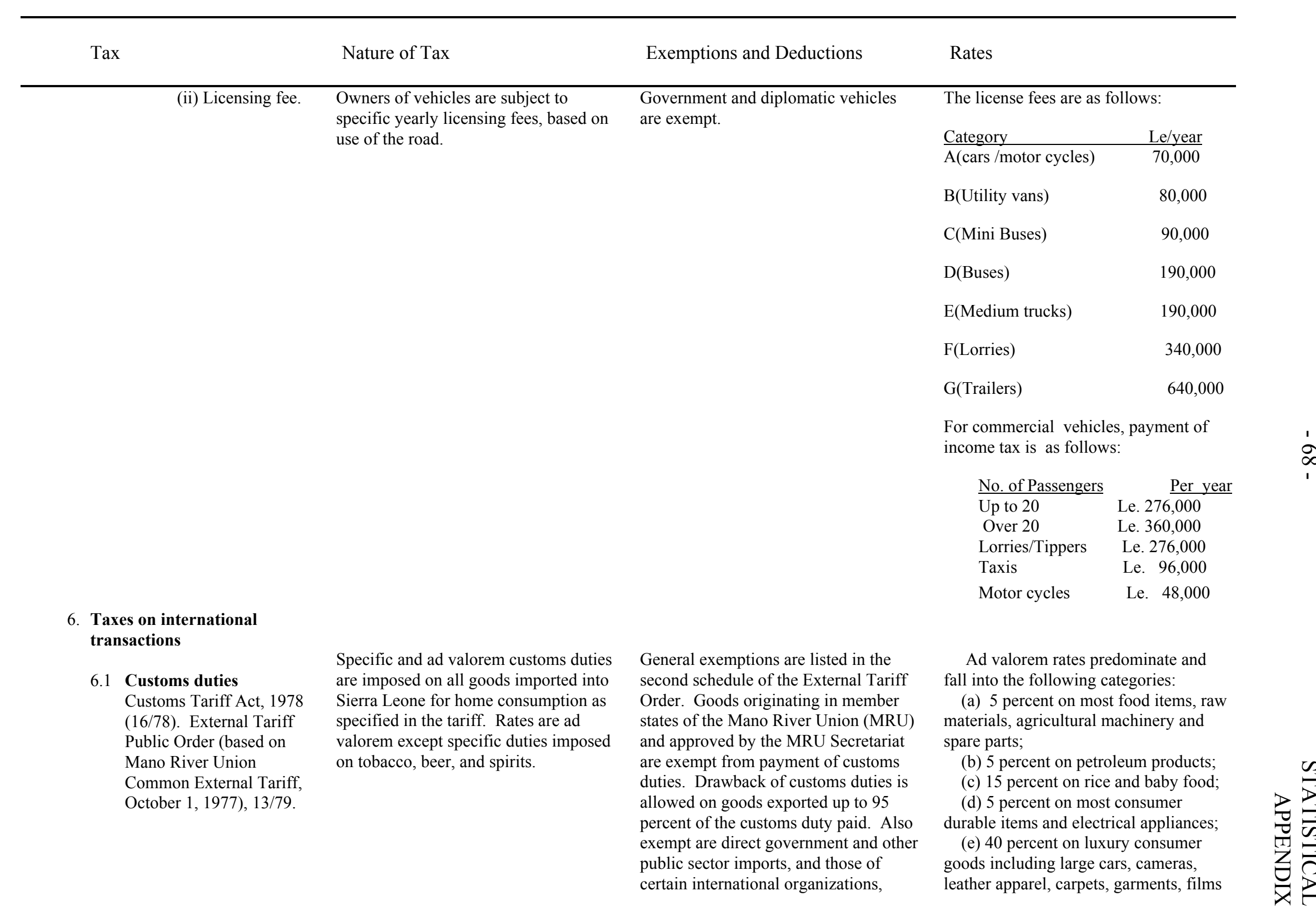


(All amounts in Leones)

Tax

Nature of Tax

Exemptions and Deductions

Rates

diplomatic representatives, and certain

West African institutions.

6.2. Excise duties

The Excise Act, 1982.

6.3. Sales tax

Sales Tax Decree 1995,

(6/95).

\subsection{Export Duties}

Customs Tariff Act, 1978

(16/78); Minerals

Concession Tax--Titanium

Agreement (Ratification)

Ordinance, 1959 (46/59)

\section{Other taxes}

7.1. Stamp duties

Stamp Duty Ordinance

(Cap. 274, R.E. 1961).
An ad valorem tax is imposed on all goods imported into Sierra Leone for home consumption that are specified in the External Tariff as being liable. An ad valorem rate is imposed on the C.I.F. value plus any customs duty paid.

A sales tax is levied on all goods imported into Sierra Leone for home consumption. An ad valorem rate is imposed on the C.I.F. value plus any customs duty paid.

All export taxes have been abolished effective June 1990 except the levy on diamond and gold export proceeds.

The levy on gold exports was removed in January 1991, but reimposed effective January 1994.

Stamp duties are levied on selected documents and instruments, mostly at specific rates, depending on the nature of the instrument. Instruments subject to the tax include legal agreements,

bills of exchange, and promissory notes, bills of lading, bonds, leases, and powers of attorney.
Any imported good is exempt from the excise duty which is not listed in the schedule to the Excise Act. No excise duty is charged on tobacco and petroleum products.

Goods listed in the second schedule of the Sales Tax Decree are exempt.

None.

Some exemptions for instruments issued to the Government or government agencies. and jewelry.

As at $12 / 08 / 2003$, new duty rates include;

Cars less than 5 years old, $5 \%$.

Cars more than 5 years old but not more than 10 years old, $10 \%$.

Cars more than 10 years old $30 \%$.

\section{0 percent}

17.5 percent

3 percent of diamond and gold export proceeds.

Rates vary according to type of instrument. 
(All amounts in Leones)

Tax

Local Tax Act, 1975

(15/75).

\author{
A form of a poll tax payable by all \\ males and all gainfully employed \\ females over the age of 21 resident in \\ Sierra Leone (i.e., resident for a period \\ or periods equal to six months in any \\ year. \\ Exemptions apply to the President, \\ members of diplomatic missions and \\ international organizations, foreign \\ technical experts, and persons who \\ would suffer undue hardship if \\ exemptions were not granted. Other \\ persons or groups of persons may be \\ exempt by Order.
}

Rates
Le 500 per person per year.

Sources: Sierra Leone Gazette, Government Printing Department, Freetown, Sierra Leone; An Introduction to Income Tax in Sierra Leone, Income Tax Department, Freetown, Sierra Leone, 1973; The External Tariff of the Republic of Sierra Leone, Government Printing Department, Freetown, Sierra Leone, 1977; African Tax

Systems, International Bureau of Fiscal Documentation Supplement No. 30, 1978; Amsterdam; African Tax System, International Bureau of Fiscal Documentation

Supplement No. 33, Autumn 1979, Amsterdam; and information provided by the Customs and Income Tax Departments. 